\title{
MEMOIRS OF THE BEGINNINGS \\ OF CONDUCTIVE PEDAGOGY AND ANDRÁS PETŐ
}

\author{
Dr Judit Forrai
}

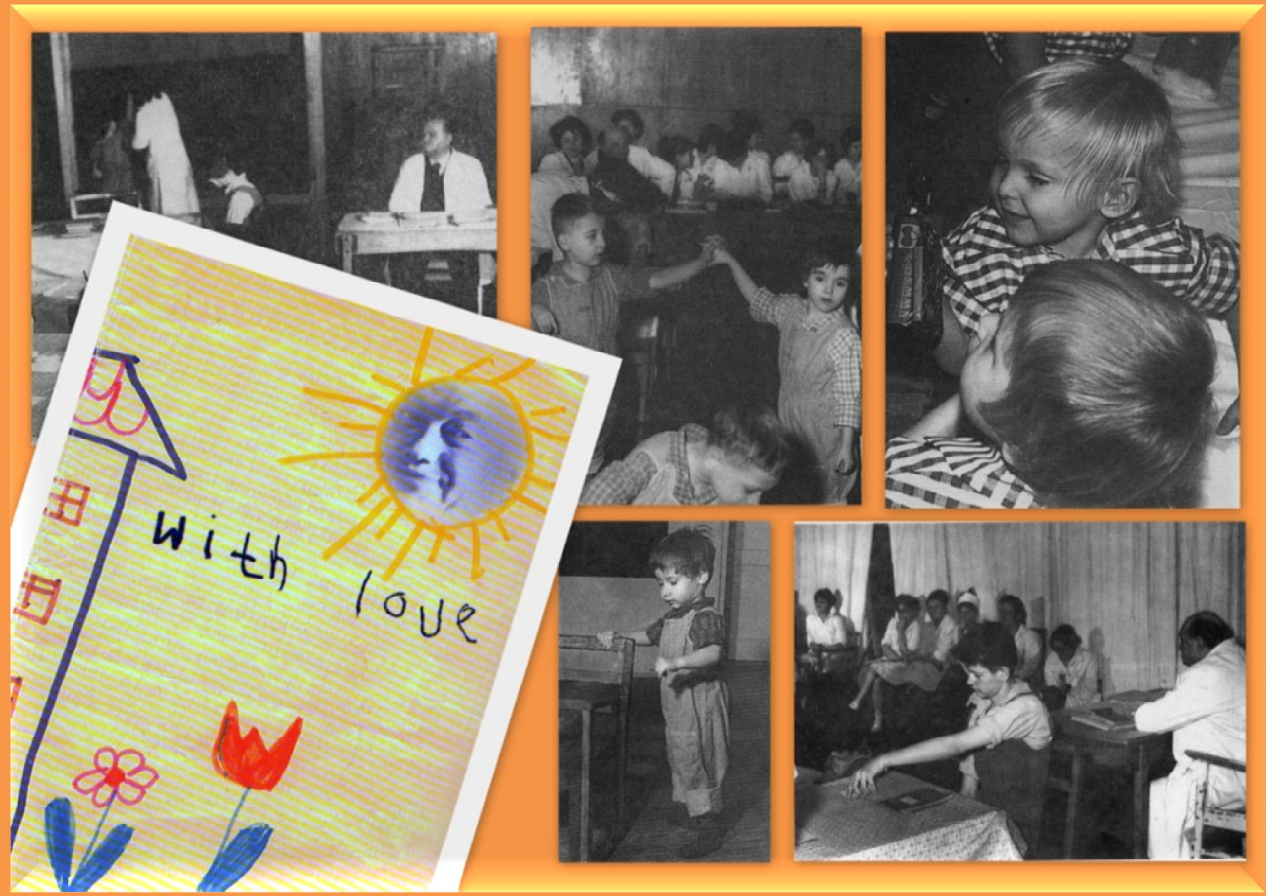

\section{KALEIDOSCOPE KÖNYVEK 2019}




\title{
MEMOIRS OF THE BEGINNINGS \\ OF CONDUCTIVE PEDAGOGY AND ANDRÁS PETŐ
}

Dr Judit Forrai

\author{
2. Edition
}

LÉTRA Alapítvány

Budapest

2019 


\section{Kaleidoscope}

\section{KALEIDOSCOPE KÖNYVEK}

Sorozatszerkesztő: Forrai Judit

Segédszerkesztő: Bilicsi Erika

\section{MEMOIRS OF THE BEGINNINGS OF CONDUCTIVE PEDAGOGY AND ANDRÁS PETŐ}

Memoirs by: Dr Károly Ákos, Béla Biszku, Dr Julia Dévai, Professor Gegesi Kiss, Dr Mária Hári, Dr Katalin Hidvégi, Dr László Horváth, Imréné Ágnes Kenyeres, Dr Miklós Kun, Dr Gábor Palotás, Professzor Péter Popper, Ili Székely, Erik Szauder

Compiled by Dr Judit Forrai

First Edition:

Published by Uj Aranyhíd, Budapest and the Foundation of Conductive Education, Birmingham 1999

Translated by Beatrix and Justin Price

Lektor: Andrew Sutton

ISBN 9638549920

Printing by OOK Press, Veszprém

Director Attila Szathmáry

Second Edition:

Published by LÉTRA Alapítvány

Coverdesign and digital edition by Andrea Pók

Budapest, 2019

DOI: https://doi.org/10.32558/peto.2019

ISBN 978-615-00-5655-5 
Author's preface 5

Towards Conductive Education ...

Conductive Education $\quad 13$

$\begin{array}{ll}\text { The roots of conductive pedagogy } & 15\end{array}$

Origins 23

First steps $\quad 31$

Polio 41

The Institute $\quad 45$

Friends and enemies $\quad 51$

$\begin{array}{ll}\text { The man } & 59\end{array}$

$\begin{array}{ll}\text { Petö's heritage } & 69\end{array}$

$\begin{array}{ll}\text { Beyond medical science } & 73\end{array}$

INTERVIEWS

Dr Miklós Kun $\quad 79$

Mrs Imre Ágnes Kenyeres $\quad 83$

Ilona Székely $\quad 89$

Prof. Pál Gegesi Kiss $\quad 93$

Prof. Péter Popper $\quad 99$

Dr Gábor Palotás 113

Dr Károly Ákos $\quad 115$

Béla Biszku 119

Dr László Horváth $\quad 125$

Dr Katalin Hidvégi 131

Erik Szauder $\quad 137$

Dr Júlia Dévai $\quad 143$

Dr Mária Hári 149

Bibliography 151

Index 153





\section{AUTHOR'S PREFACE}

In 1990 Judy and Robert Olby came to Hungary from Leeds in England bringing Peter, their fifth and youngest child, to the famous Petö Institute.

Peter, previously a totally healthy boy, became akinetic as the result of a cerebral stroke at the age of thirteen. For more than six months he was unable to move at all. His mother, Judy, worked with hearing-impaired children in England: in Budapest she followed the changes in Peter, seeing how movement returned to his inert body and how he learned exercises which he would have to use after returning to his home. As a consequence of the successful treatment Peter's father who was a professor at the University of Leeds visited Professor Emil Schultheisz, Director of the Institute of History of Medicine at Semmelweis University in Budapest. Robert Olby suggested that the history of the Petö Institute and Conductive Education should be researched and a précis of the results widely published. Professor Schultheisz honoured me by choosing me to perform this task and I began on what promised to be an exciting journey of discovery.

I became a warm friend of the Olby family. Peter's mother and I went to visit one of the most beautiful and historic towns in Hungary together and Robert and I visited Peter in the Petö Institute where he was being treated. Besides the excitement of the research I was also personally touched by the fate of Peter and his family, especially since I am myself the mother of two sons and motor disorder could happen to any family either from birth or through disease.

That is how I formed the aim to uncover the man who, through his method and through his and others' collective efforts and dedication was able to give back to motor-disordered people their faith in life and the means to make themselves independent.

There is very little written material about András Petö's life and work, his curriculum vitae, a few articles and publications, press clippings from his time and the recollections of his contemporaries, colleagues, friends and patients. These apart, I could rely only on recorded interviews with his contemporaries. A picture of András Pető emerges as an anomalous man living and working in an anomalous world. András Pető was a strange and charismatic personality revealed through his struggles as a very real, flesh-and-blood man, as I hope I will show as these pages unfold.

During my work I was privileged to meet glorious people through whom the radiance of Petö's ideas and work still shines today. I am profoundly grateful that destiny gave me the opportunity to meet them and deeply sorry never to have met the man himself. I would like to thank all the people at the International Petö Institute, the Institute of History of Medicine at the Semmelweis University of Medicine and the National Scientific Research Foundation (OTKA) for making this research possible. My thanks go also to all those who contributed to my work and helped in publishing this book. Last but not least I would like to express my heart-felt gratitude to the Olby family for it was through them I came to know András Petö. 
Many have been disappointed in me. Some expected me tobecome an eminent mathematician, some the future greatest Hungarian poet, some believed that I would stay with Pester Lloyd and become a Germanspeaking journalist in Budapest. Others took me to be a German bard. Yet others thought I would become the leading light of physiotherapy. Two famous clinics in Vienna invited me to become an assistant lecturer. The Institute of Physiology even appointed me as demonstrator. I have not become anything. But I have piled adventure upon adventure, anguish upon anguish, joy upon joy, often not knowing where my next meal was coming from. If I singed my wings too badly on the flame of destiny then I would take a position as doctor at an institute of some kind a sanatorium for consumptives, a physiotherapeutic institute or a mental hospital. Later I became by turns a medical journalist, editor of a medical periodical and director of a medical publisher. I have started many ventures in Vienna, Paris and even in Budapest! I had just founded a medical and scientific publisher in Paris when war broke out. I came to Budapest at the request of a friend and his wife, and became involved in movement therapy. I became famous, and paid taxes under the heading of physiotherapist. After the war one of my former patients pressured me into the College of Special Education, from which began what after overcoming many trials and tribulation became the Institute you have seen. 


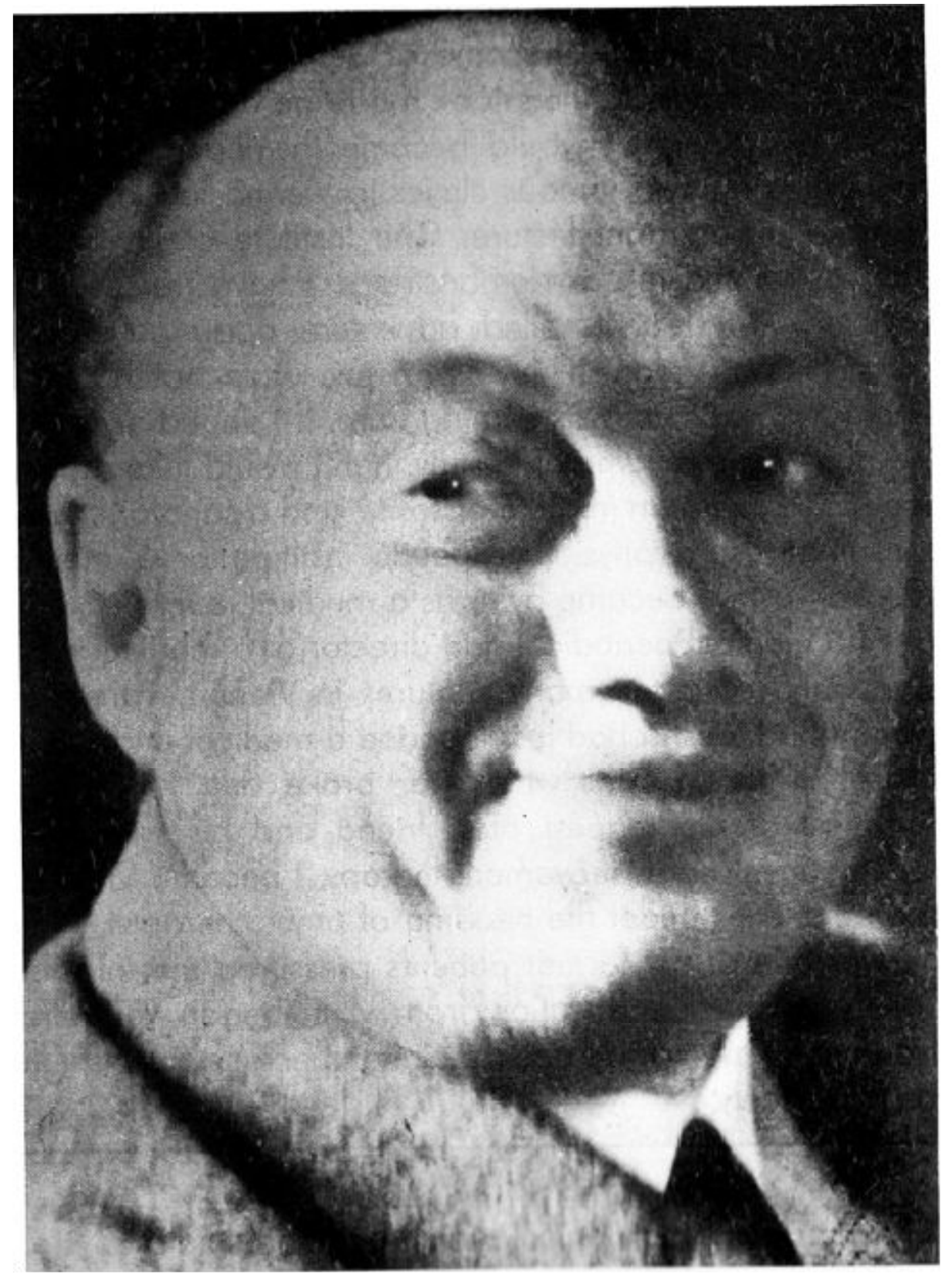

Pető András (1893-1967) 



\section{TOWARDS CONDUCTIVE EDUCATION}

\section{An introduction by Andrew Sutton}

As the twentieth century ends, Conductive Education, increasingly known simply by its initials CE, emerges as a potent and dynamic new force for the benefit of children and adults with difficulties in controlling movement (motor disorders). The spread of CE around the world has been to a large part due to determined advocacy by families who retain little confidence in existing systems and regard CE as a potentially effective response to their needs. In the wake of their efforts scholarly interest is beginning to examine this approach. So what is $\mathrm{CE}$, where did it come from, what is its mainspring, its essence? Empirical investigation, theoretical enquiry and practical demonstration will play an essential role in elaborating such questions: Judit Forrai's book takes us straight to the heart of the matter, to the life and work of András Petö himself and the creation of conductive pedagogy.

András Pető died in 1967, within the lifetime, even the professional lifetime of many who will read this book. He had lived and worked for the previous twenty-odd years in the capital of a small country where, it appears to the outsider, everyone seems aware to everyone else's business. Only thirty-two years after his death, however, we know remarkably little of András Petö, his practical work and thinking during the years in which he created conductive pedagogy and precious little indeed of the years that preceded this. Unlike the founders of other schools, not least his Viennese contemporaries, András Pető created no extensive corpus of published material and few of his aphorisms and dicta live on by word of mouth. As for András Pető himself, during his long professional gestation in Austria between two wars and the conductive years in Budapest that followed, whether by accident or design the man himself has all but disappeared.

Over the nineties brief descriptions in English have come from the Petö Institute, 1,2 along with Mari Hári's major compilation in Hungarian,3 and further contributions towards the emerging field of Pető Studies from the Foundation for Conductive Education 4,5,6,7,8,9 Now Judit Forrai offers English-language readers a investigation into Petö's creation of conductive pedagogy within the covers of a single book, a major contribution both to Petö Studies and to the conductive movement as a whole.

\footnotetext{
${ }^{1}$ M. Hári (ed.) Pető András (1893-1993), Budapest, Pető Institute, 1993

2 J. Horváth, András Pető a brief biographical sketch, Occasional Papers, n o . 1, pp.1-6, 1997

${ }^{3}$ M. Hári, A konduktiv pedagógiai története, Budapest, Pető Institute, 1997

${ }^{4}$ A. Sutton, What's in a name? The Conductor, 5, nos.3-4, pp.44-46, 1997

${ }^{5}$ A. Petö, Conductive movement therapy as special education (translated into English and edited), The Conductor, 5, no. 2, 37-39, 1993

${ }^{6}$ J. Sárkány, Memories of Dr András Pető, The Conductor 6, nos. 3-4, pp. 14-15, 1995

${ }^{7}$ A. Pető, A note on the subject of neurocare (translated into English), The Conductor, 6, no. 1, pp. 14-14, 1995

${ }^{8}$ V. Forster, A view from the past, The Conductor, 6, nos, 3- 4, pp 43-46, 1997

${ }^{9}$ K. Ákos and M. Ákos, The enigmatic Dr Pető, The Conductor, , nos. 3-4, pp. 49-54, 1997
} 
This is a very Hungarian book and in editing it I have sought to maintain its Hungarian flavour. Very noticeable is the treasure-trove of personal references which to the outsider may seem mere name-dropping but, given the disruptions of recent Hungarian history, appear an important feature of biography and autobiography in Hungary. English-speaking readers should pause and reflect upon the personal and social disruptions that may underlie this for these were a vital part of the context in which András Petö developed conductive pedagogy. How the reader will 'read' such names is another matter for, whilst Hungarian orthography is regular, the sounds of the language are not widely familiar outside, Central Europe. Suffice it here to offer a crude English rendition for the names of three, main protagonists. András Petö sounds something like OND'rash PEH'tuh, Maria Hári like MAH'ria HAH'ree and Ili Székely like EEL'ee SHE'kay, all with the stress (as in all Hungarian words) very definitely on the first syllable. I must also mention the author, Judit Forrai, whose name sounds something like YOO.'dit FOH'roee. As for street names, I have followed the courteous English convention of leaving them in the original language, as út (road), utca (street) and körút (boulevard). I have taken minor liberties with Beatrix and Justin Price's excellent translation from the original Hungarian, to render it closer to contemporary English usage but a continuing problem lies around the use of the word 'cure' which might have at times been less contentiously rendered as 'heal' or 'treat'. Precisely because it is contentious I have left it as it is, since doing so might help convey some of the incomprehension and opposition from medical colleagues during András Pető's lifetime.

At the core of Judit Forrai's investigation into András Petö lies the irreplaceable personal record of men and women who knew him, irreplaceable because some of her elderly informants have subsequently died. Their taped reminiscences were faithfully transcribed (omitting only a few specifics that might hurt or harm the living) and translated into English. Judit Forrai, a medical historian, then wove extracts from these reminiscences into the historical narrative and analysis that comprise the first half of this book. Then, from my own particular background and orientation, I edited Judit Forrai's history. For those who would write their own history from the data, the original translations of the transcripts are published in full as the second part of this book.

The question must arise, how 'true' is the portrait of András Pető presented here? We have to acknowledge that we are dealing with the reminiscences of later life and, as Péter Popper so readily accounts, 'Look, we are all great story-tellers and of course we exaggerate a little, all of us'. Readers will easily pick out some of the resulting inconsistencies for themselves. More fundamentally, however, we are dealing here the large part with people who not only knew András Petô but whose lives were often' powerfully affected by him, at pivotal points in the years of their youth and at a time when their society was in turmoil. After all these years András Pető still holds them in thrall. Was he indeed a 'polyhistor', was he really such a terrible loss to German literature - or was he a dabbler with a colossal ego, heroworshipped by youthful and impressionable admirers? Further scholarly enquiry by Hungarian- and German speaking scholars is needed before firm documentary evidence permits us to know for sure, one way or the other.

Two things, however, are certain from Judit Forrai's interviews. Firstly, at least for those who fell under his sway, his patients, his staff and those who formed his circle, András Petö's will and determination were cardinal features in his personal and social life, his professional career and his very method. Secondly, whatever his considerable achievements, certainly in the last twenty or so years of his life, András Pető was no angel and these reminiscences offer no hagiography. This may come as a surprise to some as it did to me when some years ago I had a long and open conversation with a lady who had known András Pető in the fifties and sixties 
and held his clinical skills and insights in very high regard, his personal behaviour much less so. At the end I remarked, 'So Pető was a horrible man?' 'No', she emphatically replied, 'he was not horrible, he was disgusting'. Heroes do have feet of clay and András Pető's achievement is no less for the contradictions of his personality. Again, further scholarship is required, not least to reveal the man himself in the midst of all this. What did he feel about what he was doing and the life he led. Judit Forrai's investigation offers tantalising hints.

The fundamental principle of what the world now calls Conductive Education, without winch all other so-called 'principles of CE' are worthless, is what András Petô in his own time and place found it politically advantageous to term conductive pedagogy. Behind this lies an understanding of the essential, non-reducible unity of human beings and the dependence of our humanity upon social relations. Two distinguished Hungarians summarise this very well in these pages:

He taught the conductors how to work with the children through emotions and through emotions you could work with them intellectually and develop their movement at the same time. (Professor Pál Gegesi Kiss)

and

... we always have to think that, if there are connections within the central nervous at all, then miraculously the function will be regained to a certain extent. This can only be achieved, however, with enormous work and outstanding enthusiasm patient and conductor alike, with steady practice and consistently maintaining a standard, and continually raising of that standard. (Professor János Szentágothai).

But it is term 'pedagogy' with its didactic associations enough to encompass the nature and the outcome of the conductive process? András Petö himself published only one book, and this under a pseudonym ${ }^{10}$. In this book conductive pedagogy received barely a mention (indeed he left it to a visitor to his Institute to describe) but he did write of seelische Heilung 'healing of the soul', a notion which seems in accord with the experience of many children and adults — and their families - who have experienced Conductive Education. Elsewhere I myself have treated Conductive Education as a special education but also argued that $\mathrm{CE}$ might be profitably investigated as a psychotherapy ${ }^{11}$.

Upon more mature consideration, I have proposed that learners may acquire two psychological qualities out of the conductive process:

independent willingness to find their own, new solutions to fresh and unfamiliar problems, to learn independently (what the conductive world calls 'orthofunctioning');

equanimity and determined self-confidence in the face of their continuing chronic condition.

Perhaps these are the same thing, described simultaneously from pedagogic and therapeutic standpoints ${ }^{12}$. Judit Forrai's history suggests that the physician András Petö, amongst others in his time and place, used a 'movement therapy', more likely a combination of such, to treat a wide range of chronic human conditions and, in the hands of a man of indomitable will, unusual interests and a fairly free rein to do as he wished, his method developed as a pedagogy, a healing, cutting across hoary old dualisms of teaching and therapy, mind and body, emotion and intellect, teacher and learner, health and education.

\footnotetext{
${ }^{10}$ K.O. Bärnklau [A. Pető, Unflug der Krankheit] — Triumph der Heilkunst, Hanau/Main, Verlag Karl Schuster, 1965

${ }^{11} \mathrm{Ph}$. Cottam, A Sutton (eds.) Conductive Education, London, Croom Helm, 1985, pp. 173-174

${ }^{12}$ A. Sutton, Conductive Education and cognitive education, Paper presented at the Seventh Biennial Conference of the International Association of Cognitive Education, University of Calgary, June 1999 (submitted for publication)
} 
The central mysteries of András Petö, however, prevail. What precisely were his ideas, where did they come from? András Pető's publicly stated position made play of I. P. Pavlov, though this is hardly surprising in the circumstances of his time. Quite contradictorily, we see in the pages of this book clear indication of intellectual interests which would today be identified as New Age. We see too how András Petö's practice emerged generically out of the circumstances in which he worked, from the demands posed by himself, has patients and his workforce and the conditions in which they had to live. A telling example is the arrival of the concentration camp bed, prior to the activities that developed upon it. We have also to remember that the detail in the reminiscences presented here cover only the last twenty-three years of András Petö's life, in which he created his method, founded his Institute, lost his health, broke from the Health Ministry, fell ill and died. A hectic and creative time but what happened over his preceding fifty years. English-language readers can catch an oblique and fascinating glimpse of András Pető as a medical student in René Marineau's biography of Jacob Moreno ${ }^{13}$ and savour the strange atmosphere within Moreno's circle, but from then till the closing year of the Second World War there remains but a scattering of brief and inconsistent reports. Again, further scholarship is required to elucidate the influences that impinged upon András Petö over those years and how they contributed to what was to follow.

We are still left with questions of how conductive pedagogy changed and developed following András Petö's death, to create what many regard now as the 'classic' system that so entranced Western visitor in the seventies and early eighties, why these changes came about and what was the outcome? Then what further changes resulted from the deluge of visitors from outside Hungary in the late eighties and then the collapse of the old regime, its social values and funding structures? More cogently today, what are the effects of the formal projects and the vast array of informal attempts around the world to transfer András Petö's method to altogether new contexts and social systems? How will András Petö's original inspiration and his will to better his patients survive in the more permissive world of the liberal democracies where users of services demand choice yet, paradoxically, services themselves are increasingly enmeshed in managerial controls in their own way more inimical to innovation and creativity than those faced by András Pető under Rákosi.

So who was András Pető? In Judit Forrai's words, 'an anomalous man living and working in an anomalous world' but a man whose heritage still proves potent in the very different world in which we live today.

\footnotetext{
${ }^{13}$ R. F. Marineau, Jacob Levy Moreno (1889-1974), New York, Tavistock Routledge, 1989, Chapter 3
} 
András Pető created Conductive Education, the essence of which is to change incorrect ay of working, dysfunction, into correct ones, orthofunction, by means of conductive pedagogy.

Conductive pedagogy inspires learners to become active for themselves, as participants in the educational process, and become more and more independent within it. The conductor does the leading. In the case of children and adults with motor-disorders 'it is not concerned with a healing therapy for specific functions, rather with establishing a potential co-ordinated functioning, ${ }^{,}$. Conductive pedagogy is a method that does not treat separate muscles or limbs but turns cortical functions into events. ${ }^{2}$ Certain elements of the method were already known but Petô deserves credit for systematising this education. It is therefore understandable that professionals with whom András Petö had some kind of connection give meaning to the essence of conductive pedagogy according to their own ideas, from the viewpoint of their own fields. For example Academican Pál Gegesi Kiss understands the method in the following way: $^{3}$

Peto" showed that it was worth working with the problem - and it is an important problem because clinically we are totally impotent in the face of these patients, we can treat only their symptoms - and that it is worth building up an institute where you can prepare another system and put it into practice. He showed that you can get students and as we have seen you can also become famous, because I think that is what he is. Of course he need help to found his institute and actually to run it, economically, politically and spiritually. I supported him spiritually and gave him a chance. ...Petö convinced us, Ortutay ${ }^{4}$, Biszku ${ }^{5}$, that this problem was worth working with. I found it natural that Peto turned to me, not only because I had authority but also because I agreed with the concept and its practical application in cases of motor disorders, where previously only orthopaedic solutions were used. He tried to solve these cases through working with the children's personalities by psychological means. If you go into that Institute now, you will see the conductor doing all she can to win the children through mutual work and love and in return the child is making a big effort to please the conductor. This mechanism is able to overcome a disposition called 'inactive atroph', which is not a physical deformation but consequently remodels the whole personality. This is the essence o this technique. Because you do need a technique to know how to move a few monthsold infant, or one already learning to walk or one who is completely paralysed.

According to László Horváth: ${ }^{6}$

Petö treated motor disorder and lack of motor function with directed movement education, which is very strange and one could easily find fault with it - and people certainly did. There is definitely a need for it because the requirement and pressure of society are so great that even the Institute they built on Kútvölgyi Street proved to be too small.

\footnotetext{
1 Ildikó Kozma: The special content, quality and structure of the conductor training. First World Congress on Conductive Education. Budapest 1990. MPANNI p 11

${ }^{2}$ András Pető: Conductive movement, therapy as special education. In Gyógypedagógia, Vol. I. Jan.-April 1955.

${ }^{3}$ Interview with Professor Pál Gegesi Kiss

${ }^{4}$ Gyula Ortutay (1910-1978) Academic, ethnographer, politician, Vice Chancellor of the University of Budapest, 1947-1960, Minister of Religion and Public Education, 1958-78. Member of the Council of Ministers.

${ }^{5}$ Béla Biszku (1921-2016) 1957-61 Minister off Domestic Affairs, 1961-62 Vice-President of the Cabinet of

Ministers

${ }^{6}$ Interview with Dr László Horváth
} 
Miklós Tomcsik ${ }^{7}$ who teaches anatomy in the Pető Institute sees the advantage and newness of the method in his own way:

What I understood from Peto" was that he created a special psychological and educational method. I think that the greatest thing about Petö was that he used both healing and education at the same time. This is my conclusion as an anatomist. The conductors needed knowledge of both anatomy and neurology because they had to know that if the muscles in a group do not work together then the cause could be either of central or of peripheral origin, or there could be spinal damage. The other wonderful thing in Petö's method is that movement is always tied to a many-faceted re-enforcement. That is augmenting articulated intention. They not only say what they are going to do whilst preparing to move but the conductor also demonstrates the movement, and in this way the patient is consciously re-enforced both in an audible and a visual way. And at the same time they can see their neighbours too. So they receive reenforcing stimuli from all directions. Individuals do not carry such a burden of responsibility when, for example,' singing or speaking a poem in chorus, since if they do not know a few words then are hidden by the many. There is no risk and hence one does not have to feel nervous - if one gets left behind then one can pick up the thread a couple of lines later. There is no problem, the next time they all say it in chorus they will know it. As the children do all their tasks together in groups of ten or fifteen, they are not worried about having their performance watched and analysed. In this way working in a group reduces their tension.

\footnotetext{
${ }^{7}$ Interview with Dr Miklós Tomcsik
} 


\section{THE ROOTS OF CONDUCTIVE PEDAGOGY}

Methods that simultaneously heal and educate were born in the human-centred age of the, Renaissance. Renaissance Man believed in the effect of systematic education, especially in the case of the disabled. The basic requirements of education were firm discipline, ardent practice, moral education and of course no overload. Many famous humanist scholars worked with this problem, Rudolf Agricola, Juan Pablo de Bonet, Hieronymus Cardanus, Ramirez de Carrion, Desiderius Erasmus, Mercurius van Helmont, Martin Luther, Hieronymus Mercurialis, Paracelsus, Francesco Petrarca, Pedro de Ponce etc. Conductive Education stands on the frontier of two branches of knowledge, with healing its goal and education its method. Thinkers of later ages continued to elaborate the theories. Among eminent scholars who worked with special education was Jan Amos Comenius (1592-1670), a Czech teacher whose life work reformed the educational practice of the time and laid the foundations for the governing principles of modem education. He developed the way of working with the disabled in which sensory functioning and patient teaching play a great part. He condemned the then fashionable physical punishment as a method of education.

In the eighteenth century both educational and medical science went through great changes. New governmental frameworks were born, which meant the partial end of clerical supervision. Ratio Educationis (1777), a decree of Maria Theresa ${ }^{8}$, gave space to aspirations such as partially free education with useful practical subjects such as gymnastics built into the curriculum. Gerhard van Swieten (1700-1772), a doctor of the Viennese court and one of the student Herman Boerhave, as given the task of organizing Hungarian health matters. He founded the Medical Faculty of the University of Nagyszombat (1769), and organized allocation of doctors in the counties (Generale Normativum in Re Sanitatis, 1770). He also developed a plan to found an institution for the disabled. Johann Peter Frank (1745-1821) suggested work therapy in such cases while Felbiger made an educational plan or them, independent of the government's. In 1770 a special institution was established for the deaf and dumb in Paris, after which one closed institution after another was founded for blind and deaf people in Europe. There was no mention of treating the motor-disordered.

Specialisation of medical science began in the eighteenth century. The development of neuro-pathology started with Pinel, whose student Esquirol dealt with questions of mental disability. The appearance and growth of orthopaedics and the recognition and documentation of movement disorders were linked to the name of Nicholas Andry (1658-1742). The life work of Johan Heinrich Pestalozzi (1746-1827) had a decisive effect on the institutional development of the disabled. He established a home and a model farm for abandoned and socially difficult children. He considered work an important educational tool because it demanded systematic order and rhythm, making it possible for teaching and learning to shape the child's character simultaneously. His complex method included counting, measuring, drawing and teaching the mother tongue. He also developed an interest in disabled children. A patient called Mind, who communicated through only one channel, his drawings, caught his attention. It was no accident that Petó initially called his own institute the Pestalozzi Polyclinic.

An outstanding member of the French school, Jean Gaspard Marie Itard, (1775-1838) discovered two new and essential principles of special education, that development of one function enhances the working of all the others and that imitation plays a major role in the

\footnotetext{
${ }^{8}$ Maria Theresa (1717-1780) Habsburg Empress between 1740 and 1780, Hungarian Chech queen.
} 
learning process. Consequently, development of capabilities and faculties is very important in establishing the 'physiological learning method'. Edouard Seguin (1812-1880) further developed his master's method:

a) conscious education must be started as early as possible, before school-starting age, which means that mothers have to be taught healing educational ways to apply at home

b) it is essential that teaching should be varied and its rhythm suited to individuals' needs, and that collective work and directed play cannot be result-oriented, rather activity its, needs to become the goal;

c) there are no hopeless cases and the intellectual abilities of all disabled people may be developed. ${ }^{9}$

These three perceptions form the basis for Petö's method.

In the beginning of the nineteenth century institutions were founded for mentally disabled children in Austria and Switzerland. It was a step forward when a curriculum was made for the pupils. Hans Jacob Guggenbuhl (1816-63) ran an institute in Adenberg which was a combination of hospital and school where doctor and teacher worked with the children simultaneously. They provided outdoor gymnastics as well as treating the patients with medicines. In the beginning of the twentieth century rhythm and movement played essential roles in the formation of new types of schools, such as calisthenics, Waldorf or Steiner schools, and the much later established Kodály schools ${ }^{10}$. Qualities of these schools were also basic elements of Petö's method.

In the coffee-houses of the European capitals there was talk of Rudolf Steiner (1861-1925), an eminent physicist of the time. At first he was an anarchist, later a scholar close to theosophy, who founded anthroposophy. He was a great admirer of Goethe whose natural-science works he explained on an irrational basis. The director of the Waldorf Astoria cigarette factory in Germany asked Steiner to work out the best conceivable modern pedagogical method for the children of his factory workers and so was born the later well known school system, Waldorf or Steiner education. Steiner's basic philosophy developed both the intellect and the whole human being, including emotional and physical capacities. Steiner blended Eastern understandings of the human being into his thinking, interaction of body, soul and spirit. $\mathrm{He}$ imagined this threefold connection as concentric circles. In the middle stands the bodily nature of humans, the next circle is perception and motivations and the third one is the individual. $\mathrm{He}$ drew from ancient Chinese and Indian philosophy and medicine, as well as from Aristotelian philosophy, and linked these to modern psychology, medicine and pedagogy. The first Waldorf School was founded in 1919, in Stuttgart, at which time its co-educational system was unheard of. The first eight years of the twelve-year learning process were built around a single most important person, the class teacher. The essential thing was not to know all the specialist fields of knowledge but to establish a firm and personal relationship with the children and develop psychological self-knowledge. The arts played an important role, singing, music, learning an instrument (recorder) and calisthenics. According to Steiner all humans have a sense for music but it is a question of whether this sense stays repressed or is successfully brought the surface. His belief is the same as Kodály's: there are no 'musically illiterate' children, all are capable of making music and feeling rhythm. Because children can express feelings through the arts, it is a school of the heart; because they do blacksmithing and pottery, work with metals and wood and learn geodesy, it is a school of the hand; and because certain subjects are taught in a

\footnotetext{
${ }^{9}$ Anna Szabó Gordos: The history of special education, Budapest, 1988. Tankönyvkiadó

${ }^{10}$ Zoltán Kodály (1882-1972) Composer, folklorist. He and Béla Bartók started collecting folk music. After the World War II. he was a pioneer of comprehensive music education. His education system is renowned.
} 
concentrated way, in more than one lesson per day, it is a school of the head. Steiner's philosophy and educational method had a great effect on his Hungarian contemporaries such as Sándor Karácsony, György Kontra, Sándor Török, Ottó Mihály, and other psychologists and professional educators ${ }^{11}$. Among them was Pető, who studied Steiner's writings and consulted Sándor Török ${ }^{12}$ about them on a more than weekly basis.

Petö called this method 'conductive pedagogy'. As for the how and the why, Ilona Székely ${ }^{13}$ the first leading conductor tells us the following:

Many time he held so-called open sessions. During these he gave new tasks to the group but the exact way in which we helped, 'facilitated', we had to make up for ourselves. We had to help as if we were not actually helping. This is hard to understand but it is what Conductive Education is, leading directing. The solitary violinist needs no conductor: the sheets of music and his own soul direct the making of music. This is what conduction is.

Petö worked intensively on the form, content and duration of the training. What we were called changed many times: we were movement therapists, child nurses, but none of the names covered what we were actually doing. He was looking for a special training and a name that would easily be told apart from everything and everyone else. Because the world could hardly understand what we were doing, they could not really put it into words either. Foreigners were already showing interest and we still didn't have an acceptable name. The method continuously changed. The phrases 'to correct' or 'to rehabilitate' caused Petö enormous problems because he didn't want people to think o us as physiotherapists, which would have put the independence of the Institute into doubt.

Then 'healing education' was thought of but he rejected that too. In essence, the conductor is a professionally trained mother who directs or conducts the activity of her child. In this process everything we do is included, because it is the mother who teaches the child to sit, walk, talk and live.

In Petö's method, it is the conductor who assumes this role.

$* * *$

After Pető's death Károly Ákos ${ }^{14}$ offered a technical explanation of the essence of the method. ${ }^{15}$

The medical literature about motor-disordered children is inadequate in its theoretical content. It can neither give a clear picture of the affected children's situation nor provide sufficiently useful therapeutic instructions. Specialists agree that the symptoms of motordysfunctional children are caused by brain damage. They do not agree what sort of brain damage it is and how it is connected with the symptoms. Research into the brain supplies a lot of detailed knowledge but unfortunately this is not very useful for motor-disordered children. It is generally believed that structural brain damage is irreversible. Often the symptoms increase with age but sometimes they diminish or disappear totally. Various theoretical reasons are given for therapeutic methods of treatment of handicapped children but these do not agree with each other.

All movements - the autonomic and the two groups of infantile activity - are expressions of complicated brain functions. The brain with its impenetrable complexity of specific functions resembles a 'black box.' This means that only the results of its total functioning are visible, for

\footnotetext{
${ }^{11}$ Tamás Vekerdy: Álmok és lidércek, Budapest, 1992. T-Twins

${ }^{12}$ Sándor Török (1904-1985) Writer, drama-translator

${ }^{13}$ Interview with Ilona Székely

${ }^{14}$ Dr Károly Ákos physician, psychologist, psychochronographist.

${ }^{15}$ Ákos, K. and Ákos, M.: Dina. A mother practices Conductive Education. Birmingham and Lm, 1991
} 
example as natural movements. On the basis of the co-ordinating and integrating general function some specific functions of the 'black box' can be understood. The total functioning is not a simple combination of specific functions but the meaning of some specific functions becomes clear if the whole is considered.

Increasingly the mother experiences that her infant helps her, then takes over from her and so becomes more independent. This change is interpreted and encouraged by the mother as learning. For example, when feeding the child she gets the impression from the awkward and fidgety movements of his hands that he wants to hold the bottle, so she holds it in a way that enables him to succeed. Then she holds his hands, to strengthen his grip, and lets him drink. She gives the child time to help lift the bottle. This then makes his activity meaningful (after satisfying his thirst): it has proved a functionally expedient activity. In the brain's functioning a progressive feedback control system develops, in which the anticipated goal is strengthened through reference. These efforts become increasingly efficient through use insimilar situations.

The 'raw material' for the mother's teaching is supplied by casual, non-functional movements. Her teaching activity may be compared to a phenomenon often observed in biology, that chance variations present the items of choice for selection. The mother can choose from the infant's casual movements those which are most appropriate to her activity, she can use them and so reinforce them in a learning process. Competing, less useful variations of movement gradually diminish.

There are several competing patterns at the level of brain function. The pattern that dominates has adapted itself best to present conditions and gained over initially similarly strong patterns, rendering movements more and more differentiated and appropriate to circumstances. Competition also takes place at higher levels of brain function.

...In similar situations the infant's brain suggests similar variations of movements, like fidgeting with the hands. From these available movements the mother chooses the one which she can use best. Thus she selects but she is not aware of choosing the most appropriate movements from a set of variants. This enables her to teach her child to become more dextrous in his various movements. The infant's brain function produces variation in the form of casual movements, which the mother uses for positive selection. The dependence of motor-disordered children, therefore, is caused by a lack of casual movements from which the mother can select those to be learned by the infant.

Contrary to healthy infants, whose casual movements of undifferentiated fidgeting and thrashing change into complex and varied movements within some weeks or months, infants with motor-disorders do not show these changes. Their casual movements are very limited from the beginning (in spastic children) or they are gross, shapeless, unfamiliar 'hyperkinetic' movements (excess movements of children with athetosis), that do not diminish with increasing age but rather increase. Without appropriate conductive pedagogical help the mother cannot use these movements in her interaction with her infant. ... The help given by the mother is combined with movements during the infant's period of activity in such a way that the movements of both mother and child form a 'dialogue' that results in the infant achieving his aim. At first only the mother is able to organise the infant's activity effectively by her cooperation. She makes use of the child's casual movements which become increasingly dextrous owing to this conductive pedagogy. At first the child is able to drink (to return to this example) only with the mother's co-operation. Soon she finds that from day to day her child helps more and becomes more dextrous. He gets better at holding his head up, opening and closing his mouth, and so on. These partial movements are selected by the mother from various available casual movements. The child learns them because they have satisfied his needs. ...The infant assists his mother in their collaborative satisfaction of his needs (his primary motivation), the 
mother reacts to this with an expression of contentment (his secondary motivation) and this makes her education for independence more effective.

Now we return to a question which arises with motor-disordered children: how can the impaired development of casual, non-functional movements be set back in motion? The answer is clear: firstly, motivation has to be intensified; secondly, even the smallest attempts at movement have to be recognised and supported educationally. But what kind of motivation, can be intensified? Generally, motivation must not be intensified if its goal is reached by the mother's co-operating with the child in satisfying his needs. If a hungry or thirsty child is kept hungry or thirsty this may do him harm. It is much more effective in intensifying the child's motivation in support his mother's help, if the mother learns to recognise and to promote her child's attempts at movement and to guide them so that he achieves his goal. It is precisely these attempts which the mother can and should support by words of encouragement, by demonstration and by help.

The human brain can be compared with a computer in that it is constantly reprogrammed. For this, partial programmes of casual movements are necessary, integrated by the mother's co-operation into more complex programmes. It is true that the symptoms of motor-disorder are caused by defective partial programmes: for further development, however, these are not decisive. The crux of the matter is the impaired development of the group of casual nonfunctional movements and the non-appearance of these movements' growing differentiation and variation. To be able to give the necessary help the mother has to support the child's motivation both for play and for helping her (becoming independent). In her educative cooperation the mother can compensate for the defective partial programmes in the same way as she would with the initially clumsy movements of a healthy infant.

Only there is no deletion of the defective partial programme in this computer: it can not simply be replaced by an intact one. This helps to explain why illness may be enough to revive previous symptoms even if the process of overcoming the difficulties of a motor-disordered child has already successfully begun. The compensatory pattern is not yet strong enough to dominate. The same is true when there is a premature end or interruption to the Petó-system, which may mean that movements which had not been sufficiently strengthened will be lost again and the child's condition will worsen, with old symptoms possibly even reoccurring.

Because biologically the mother has the 'monopoly' over her child's personality development during the first three years, she is trained as 'programmer' in the Peto-system. The advantage here is that she is expected to do what she would be able to do spontaneously under 'normal conditions'. The only difference is that she will need instruction in the aggravated situation (this instruction is mainly practical and requires the use of simple equipment). It is no surprising to mothers to be told to occupy themselves with their children constantly throughout the day, since any mother would do that with her healthy child anyway. Nor is there any difficulty to discover when they are playing satisfactorily with their children: this they can see from their children's happiness, the lessening of symptoms and increase in independence. It is basically the same for older children. Only the conditions coverning the 'programme' and the education change.

We think that we have made it sufficiently clear why the motivations which support the child's attention and activity are central to the Petö-system. Consequently, there are neither exercises without motivation, nor passive exercise nor forced inhibitory measures conductive pedagogy. We have tried to explain why a child learns natural movements in the Petö-system. Abstract movements, 'exercises', cannot be developed naturally and be integrated into practical activities. 
In summary we want to state that conductive pedagogy is not a 'method' in the usual sense but practicing a way of life orientated towards healthy, happy children, under conditions which make personality development more difficult. This is of general importance since changes in infantile movements represent the beginning of human-biological functional alterations in the brain, of general personality development. The example of motor-disordered children shows that there is an effective route towards successful development even under conditions unfavourable for learning and teaching.

$$
* * *
$$

In 1955 Petö described his circle of patients in the following way:

The reputation of the Institute aroused the interest of paediatricians and the investigating comission stated in its report that patients can be successfully treated in the Institute. And this in spite of fact that those who ended up here were usually the ones who had been sent away from other places as incurable cases or had not even been admitted there. To this group belonged those with motor disorder due to cerebral damage, those who suffered child paralysis and for whom all hope of healing had already been abandoned, and those cases of paralysis that were caused by accidents or other damage. The patients varied in age, they could not change their position or use their limbs consciously and they had been treated in other institutions without any success. ${ }^{16}$

Ilona Székely, the first leading conductor, characterises the patients who applied in the early period:

In the beginning were limp, paralysed and spastic patients, those with Parkinson's disease, men and women all mixed together. Adults were not separated according to their sex during the sessions. ${ }^{17}$

In András Pető's own words:

We saw numerous patients who as a result of the treatment were able to change position independently and move their upper limbs - at least to the extent of satisfying practical demand, and some o them achieved complete rehabilitation. ${ }^{18}$

In tiny steps, Pető began to develop his therapy, enhancing the educational method for patients suffering from motor disorders. Initially he worked with all types of illness. László Horváth recalls Petö's telling him a story:

I was shouting after a man:

'Give me your ticket!'

What ticket? Why, what did I do?'

You were running after the tram but you didn't catch it.'

He had a ticket. 'Give me your ticket!'

Humbly he handed it over: 'I apologise, Doctor Petö, I didn't know it was you shouting after me.'

This man who ran after the tram had a serious case of multiple sclerosis. So tell me, was the diagnosis wrong or did Petö work wonders with the patients? He was a young man and he

\footnotetext{
${ }^{16}$ András Pető: Conductive Movement Therapy as Special Education, Gyógypedagógia, Vol. I. January-April 1955 p. 16.

${ }^{17}$ Interview with Ilona Székely

${ }^{18}$ András Pető: Conductive Movement Therapy as Special Education, Gyógypedagógia, Vol. I. January-April 1955 p. 16.
} 
ran after the tram. Petö was a strange man. He kept the ticket of this young man as a souvenir. He had charisma.

Miklós Kun, a friend of Petö's, talks of a wide circle of patients whom Petö successfully rehabilitated thanks to the method:

I am sure Petö had no doubts about his ability to heal sick children. He made them exercise from morning to evening and he was able to achieve a lot with them, even people with HeineMedin or multiple sclerosis. He wanted to solve almost all problems through conduction. For example, in the case of hyperthyreosis you had to do the following exercise: Count one-twothree-four-glaza-glaza-glaza. I don't know if it healed the children with hyperthyreosis but he did the same thing with those who were effected with Heine-Medin or spina bifida. He made them stand up and say:

'Hold the chair and step: one-two-three-four. I step forward: one-two-three-four. I step together: one-two-three-four I step forward.'

And this went on from morning to night. The children got really tired and so did the conductors but after an afternoon's rest it started all over again. Merciless work that is what it was. $^{19}$

He even wanted to treat speech disabilities with continuous exercise, such as when one cannot pronounce the sound ' $r$ ' There was a young man who drove the children back and forth. He couldn't say ' $r$ '. Whenever he met Petö he had to say 'Good morrrning dearrr sirrr, deerrr, deerrr, duurr, duurr.' (he had to practise). Once the phone was ringing when Peto" entered the room and the boy picked up the phone and said: 'Good morrning dear-rr sirrr, deerrr, deerrr, duurr, duurr'. Petö shouted at him: 'You idiot! What will the caller think, what kind of an Institute is this? "20

He never accepted money or financial remuneration for his work. Petö was ready to work with anyone, it didn't matter if they had money or not. There were people he could heal and others he could not. For example, a child with spina bifida and incontinence - well, he worked with him effectively as well. From this point of view he was a saint. ${ }^{21}$

\footnotetext{
${ }^{19}$ Interview with Dr László Horváth

${ }^{20}$ Ibid.

${ }^{21}$ Idid.
} 



\section{ORIGINS}

To sketch András Pető's life story we have very few sources to rely on, his own autobiographical notes ${ }^{22}$ and those of Mária Hári, ${ }^{23}$ and interviews with people who remember him.

He was born in Szombathely in 1893, the eldest child of a lower-middle-class family. His father ran a small grocery shop and was the postmaster, his mother was a teacher. According to hearsay, his father was motor- disordered. ${ }^{24}$

András Pető was a talented student. His parents lived poorly, so he paid for his education by giving private lessons. 'Part of my salary I sent home to my parents who had to take care of my two much younger brothers,' he wrote. He went first to schools in Szombathely, then finished grammar school in 1911 in Budapest. He was talented in writing and got a job at the newspaper Pester Lloyd. ${ }^{25}$ His articles caught the attention of the publisher and he was sent to Vienna with a stipend to study liberal arts. He chose medicine, however. We have no information about the reason for this decision; in his curriculum vitae he stated simply that he earned a medical degree in Vienna (July 26, 1921).

At the beginning of the twentieth century the exciting and teeming intellectual atmosphere of Vienna made a great impression on the young Petö. He became member of a circle of young people representing the intellectual elite and held discussions late into the night. Vienna was the citadel of turn-of-the-century and new-century thinking in the sciences and the arts, a meeting place of European intellectuals and home to professional workshops. It was called the capital of modernism, the field laboratory of the end of the world, Les fleurs du mal or simply: 'requiem and birth'. Europe's youngest empire, living out its last broken decades, gave space for new ideas. Musil captured the spirit of the times exactly when he said

...out of the oil-smooth spirit of Europe flared a wing-giving fever, no-one could tell whether it would be a new art-moral or a regrouping but everyone wanted to fight against what was old. Practical and intellectual desires to act either met or were different to the extremities. Talented people could develop, people whom earlier society would have suffocated. Admiration of the higher human being was fashionable just as much as of the lower, health and sunshine were loved but frailty too, people were believers and sceptics, they dreamt of royal parks and of prairies, of social equality and of the destruction of the old order. $^{26}$

In this changing political and economic world the bourgeois intellectuals, in the sciences and arts, were mainly assimilated immigrants, Slavs and Jews and to a lesser degree Hungarians and Italians. ${ }^{27}$ Through the opportunities offered by cosmopolitan liberalism they turned to the capital of Middle Europe, colourful and magical Vienna. The German-language culture of Vienna-Prague-Berlin and the creations of the scientific and artistic elite became a corner stone of modern culture. Notable representatives of literature, architecture, painting and music were Schnitzler, Hoffmannstahl, Mach, Weininger, Musil, Grillparzel, Kafka, Klimt,

\footnotetext{
${ }^{22}$ Curriculum vitae of András Pető, in a glass display cabinet at the International Petö Institute

${ }^{23}$ Dr Mária Hári: (1923 - 2001) Pető's closest colleague, the Director of the International Pető Institute (1967-1993)

${ }^{24}$ Interview with Professor Péter Popper

${ }^{25}$ The Pester Lloyd (1854-1944) was a German-language daily newspaper in Budapest, reporting on Hungarian social life. It reappeared in 1989.

${ }^{26}$ Robert Musil (1880-1942) Austrian writer. The Man Without Qualities. Vol. 1, chapter 15.

${ }^{27}$ Péter Hanák: Reflections about Viennese and Budapest culture at the turn of the Century. In A Kert és Budapest, 1988. Gondolat. pp.130-173.
} 
Wagner, Schönberg, Mahler, and Strauss. Petö’s university years were spent in this complex and exciting cosmopolitan city: a great time for founding schools of psychology.

Petö spoke and read many languages and was interested in all new waves and discoveries. After Word War I and the political changes, even more Hungarian artists and writers found asylum in Vienna. Their centre was the Hotel Imperial. These immigrants published a string of Hungarian newspapers, for example Bécsi Magyar Újság (Viennese Hungarian News) and Ma (Today) edited by Lajos Kassák. ${ }^{28}$ Andor Németh $^{29}$, a friend of Petö's with whom his way crossed more than once, found work at the Hungarian Embassy. This is how he remembers this time:

The leader of the Hungarian Embassy was a good friend of mine. He invited me to work with him and my appointment was accepted. I must count Petö, who came to see me unexpectedly one afternoon amongst my strangest visitors. The Passport Department had told him that no one could be given a passport but, since he was very insistent, the woman in charge said to him: 'Try Comrade Andor Németh.' Of course I couldn't give him a passport either but that evening in a café we revived our youth. I visited him in his rented room, among his books, and after that we met every day.

When Petö didn't need me, he didn't contact me. During these periods I let him wander free for a little while and when I started to long for his company I looked him up in his regular coffee-house on Albertstrasse. This little café was in actual fact his real home. He was always either reading or making complicated notes in his notebook of things he had to do. They were extremely complicated, because he only wrote names or a few dry key words, cream, shoemending etc. As soon as I sat down next to him he called the cigar-man so that I could buy him a couple of Virginias. That was his favourite, like the old Emperor (Franz Josef), a heavy, black cigar with a straw stalk in the middle.

In the afternoon I sat at home and worked for hours on a novel. I remember that he taught me the most important thing is to organise one's time and, regardless of whether you like writing or not, you must finish the planned portion. The novel was lost and I remember only having written about Petö's friends and of course about my friend, the enigmatic Petö. ${ }^{30}$

$* * *$

In the last third of the nineteenth century progress and development in research into brain physiology had resulted in the beginning of scientifically founded psychology. From this period we can mention two outstanding figures who represented two completely different tendencies, Freud and Pavlov. Today it is hard to reconstruct where myth and reality part company but it is certain that Freud was surrounded by lively attention, either agreement or refutation. According to his own definition he did not consider himself a doctor or a healer but a universal thinker combining the knowledge of bygone ages into himself, enriching it with new associations and discoveries. The experiments of Ivan Pavlov laid the foundation of psychopathology based upon objective research. He worked out the thesis of conditional reflex and clarified the definitions of in-born and learnt reflexes. He introduced the concept of the first and second signalling systems, which is very important pedagogically. He also found that

\footnotetext{
${ }^{28}$ Lajos Kassák (1887-1967) poet, novelist, painter, essayist. Leader of the Hungarian avant-garde movement. Founder of the literary magazines Tett (Deed) and Ma (Today).

${ }^{29}$ Andor Németh (1892-1953) writer, critic. One of the founders of the literary magazine Szép Szó (Beautiful Word), editor of Csillag (Star).

${ }^{30}$ Andor Németh: A szélén behajtva, p 594 Budapest.1973. Magvető.
} 
speech, as a conditional stimulus, made goal oriented-activity such as thinking possible through its nerve-mechanism. Pavlov's statements offered Pető's work theoretical grounds.

During his university years Pető met and befriended Jacob Levy Moreno, a well known figure in Freudian thinking in Vienna. Moreno was born in 1889, in Bucharest (Romania), to a bourgeois family. He received his medical and psychiatric degree in Vienna and was an independent and holistic thinker. The poets, playwrights and philosophers of Vienna made a great impression on him. He mentioned in his autobiography that he like Peto also wrote literary pieces. He called Shakespeare his spiritual father and worked with the literature of drama and with the history of theatre. He paid special attention to commedia dell'arte, the originally Italian improvised comedy which after its birth in the sixteenth century was taken up throughout Europe, especially France. The essence of this genre is that there are as many variations to the story as there are performances. Moreno, together with Petö, started to work with children loitering in the squares of the city. ${ }^{31}$ After a time he made them do improvisations in which their own experiences, problems and conflicts were played out and experienced again. Moreno found that drama wrought enormous change in these children, their aggressiveness lessened, their ability to solve problems increased, almost as in therapy. During his university years Moreno founded the Stegreif Theatre (Theatre of Improvisation) where he tried to embody the three founding principles of modern theatre, spontaneity, creativity and activity. Leaning on his experiences, he developed the role theory of psychodrama and later of social psychology. The goal of acting was to bring the elements of functional disorder into motion, turning them in the direction of healing. Moreno believed that play made the emotional life and the world of imagination colourful, enabling one to handle problems. Functional disorder is built up not only of verbal (cognitive) elements but it has behavioural (affective), vegetative and other components too. After Moreno, Petö introduced spontaneity into the lives of his patients as play.

According to Mária Hári, out of the schools of the behavioural revolution Pető worked intensively with Gestalt psychology. This new wave emphasised the undivided nature of the life of the soul, with the whole being more than the sum of the parts. The foundations of this theory had already been defined by Wundt (1832-1920) according to whom effort of some kind is needed to bring a secondary, higher level of organisation into the chaotic world of sensory elements. The question of the workings of body and soul were answered by psychological parallelism. The founders of this school, Max Wertheimer, Wolfgang Köhler and Kurt Koffka demonstrated their theory of perception. Ehrenfels explained his theory of melody in the same way: if a single note is changed, the whole melody changes.

Medical discoveries and researches of the time concerned details of the organism's function at the molecular level. Epoch-making discoveries were made in recognising the workings of muscle tissue. One of the most exciting medical researches was into the structure of nerve tissue and documentation of its mechanism. For identifying these biological processes Nobel Prizes were awarded to Pavlov in 1904 for explaining the reflex processes, to Golgi and Cajal in 1906 for demonstrating the structure of the nervous system, to Hillt and Meyerhof in 1922 for documenting the working mechanism of muscles, to Wagner Jaugger in 1927 for curing malaria with progressive paralysis, to Sherrington and Adrian in 1932 for shedding light on the problems of neurones, reflexes and nerve regeneration, and in 1936 to Dale and Loevi for publishing the essence of nerve-effect. Otto Meyerhof (1884-1951), a scientist from Heidelberg, researched the chemical processes of energy transformation in muscles. He and

\footnotetext{
${ }^{31}$ Mária Hári: The history of Conductive Education, Budapest, 1997.MPANNI
} 
Archibald Vivian Hill (1886-1968) received the highest international award at the same time. Hill worked out the process of oxygen heat creation in connection with muscle activity. Charles Scott Sherrington (1857-1952) contributed greatly to understanding the functioning of the nervous system. He shed light on the problems of neurones, reflexes and nerveregeneration. He coined the word 'synapses' and worked out how long-term seizures and conscious muscle-regulation work, which offered insight into the reflexes of spastic patients. Sherrington received the Nobel Prize jointly with Lord Edgar Douglas Adrian (1889-1977) who researched the potency changes of stimuli by electro-physiological methods, and the electric characteristics of brain function. He was the first to examine the localisation of epilepsy and brain lesions with the EEG. In Clark Hull's (1884-1952) system stimuli are always followed by a response. The learning process has universal laws. Learning can be made effective by the frequency of positive feedback and needs motivation (drive reduction).

Twentieth-century scientists revealed the particular functioning of the brain, the movement of muscles and the conditioning and biophysical mechanism of damaged brain centres. As exact diagnosis became possible, so did development of the right therapy. This was a revolutionary phase in medical science and practitioners regarded the results with great interest.

Petö found a job at the hospital in Grinzing, on the internal medicine and pulmonary ward. He worked in neurology and psychiatry (1919-1921) at the psychiatric clinic of the Nobel Laureate Wagner Jauregg ${ }^{32}$. In 1921 he developed an interest in orthopaedics, in the bone tuberculosis ward of the TB clinic in Grimmenstein, then in 1922 he was working beside Doctor Hecht ${ }^{33}$ at the Semmering Institute where movement therapy was used for the treatment of consumptive patients. The favourable effects of movements were used for treatment of the skeletal muscles. The time that he spent at the Semmering Institute was an important period in Petö's life as he was able to experience the different types of movement therapies used not only for acute illnesses but also for treating congenital disorders, even in some cases for children ${ }^{34}$.

Following movement therapy in Semmering, the next stage in Petö's life was in Alland where he worked for three years in a TB sanatorium (1922-1924) and spent his free time studying theoretical subjects (according to Mária Hári). Later still, he worked in the physiology department of the University of Vienna as assistant lecturer, then in a mental hospital in Steinhof, followed by Krizen and finally Mauer where he was promoted head physician. Petö wrote about that period: 'In those two institutes we treated the patients with dietetic procedures and movement therapy'.

In 1929 Pető married. He wedded Angela Ehrenstein, daughter of the curator at the Allgemeine Krankenhaus but they did not live together for as much as a minute. Later he recounted the story of his marriage to his friends by saying, 'Some people have hunch backs: I have a wife ${ }^{35}$ He dissolved his marriage in 1938, possibly to help regain Hungarian citizenship.

\footnotetext{
${ }^{32}$ Wagner Jauregg (1857-1940) as an assistant at a mental clinic he noticed that one of his patients, who would be sunk in deep depression for months at a time, improved mentally after an illness associated with high fever. He started to research into the connection between fever and mental illness, particularly incurable illnesses. He experimented with erysipelas, malarial fever and tuberculin. He introduced the use of malarial therapy in his Institute in 1917 against the creeping paralysis caused by syphilis. He received a Nobel Prize for his life's work in 1927.

${ }^{33}$ Hecht worked on the resistance of the capillary walls and their haemorrhage (Hecht's seepage symptom)

${ }^{34}$ Julia Horváth: András Pető — A brief biographical sketch. Occasional Papers. No 1 p 2.1997.

${ }^{35}$ Interview with Ilona Székely
} 
Between 1930 and 1938 Pető published, under pseudonyms, many literary and philosophical writings and just as many medical essays. He was a member of Aschner's circle $^{36}$ and editor-in-chief of the periodical Biologische Heilkunst (Biological Healing). ${ }^{37}$ In his curriculum vitae Petö wrote about his literary activities:

When I was a student they used to call me Holzinger. In point of fact Frau Holzinger was a waitress who used to pass on messages from me and with whom people could leave messages for me. Thus, through Mrs Holzinger I became Dr Holzinger and, since I was a student for more than ten years, the name continued for a long time. Holzinger's posthumous works are: I Lyrik, II Drama, III Prosa, IV Philosophie, V Das Leben des Mannes namens Nachtigall. I was invited to both East and West Germany many times, and even received a request to go to Switzerland.

Years later in a private letter he wrote on these literary juvenilia:

I'm working diligently on my posthumous writings, in four volumes: Prose, Lyrical Poetry, Drama and Philosophy. I am writing down now all the things which I did not write as a young man. ${ }^{38}$

Petö's choice of medicine as a profession seemed not to be his own but rather the workings of providence. He did not stay long in any one place and in fact was employed in nine separate positions between 1916 and 1938. He may have been driven by his thirst for knowledge but it is also possible that each time he was obliged to move on because of his brusque manners and disputatious nature, at least according to some people's recollections. Be that as it may, the variety of specialist fields in which he worked gave him a wide knowledge, an overview, and enabled him to recognise relationships within medicine. He later wrote of this:

My scientific writings deal with poliomyelitis, neurology, cardio-vascular and respiratory diseases, theoretical and practical questions relating to tuberculosis and rheumatism and their therapeutic difficulties. One of my treatises on symptomatic therapy emphasised, as early as 1926, the importance of Pavlov's conditioned reflex in the treatment of internal illnesses.

After Anschluss ${ }^{39}$ we find Petö in Budapest. We know from Andor Németh what happened:

A couple of weeks after Hitler took over Austria, I wrote a letter to Petö. Instead of an answer he showed up himself. After that he spent every afternoon at our house and at night we went out together. Sometimes in the afternoon he went down to the Seemann Cafe, where we never drank coffee but Petö always ordered that thick sausage with horseradish and mustard. Petö told us he had had inconveniences with the Nazis in Vienna. For example, they hung a board on his neck, which said 'I am a Jew' and he had to stand in front of a gate with it. In Pest, on the other hand, he lived luxuriously on some inherited Swiss money. He went to coffee houses and befriended the writer Endre Gelléri Andor. ${ }^{40}$ At this time Petö lived on the Buda side of the Danube in Budapest in a mysterious flat, with a woman who wrote short stories. Petö had a wide knowledge of many fields. Once he handed me two books and told me to write down the life story of a Jewish French missionary monk called Liebermann. He was going to be the second originally Jewish saint after St. Paul. He persuaded me to feel this task of mine was of utmost urgency, and I went to Paris with the intention of doing research in the convent of Liebermann's order. ${ }^{41}$

\footnotetext{
${ }^{36}$ Bernard Aschner (1883-1960) Austrian gynaecologist, University lecturer and researcher in Boston. He was the first to point out the internal secreting of the female gonad. He accomplished the first complete extirpation of hypophysis.

${ }^{37}$ Mária Hári: The History of Conductive Education. p. 24. Budapest 1997. MPANNI

${ }^{38}$ Letter to Stella Selby in 1950. In Mária Hári: The History of Conductive Education. p. 24. Budapest 1998. NPANNI

${ }^{39}$ The annexation of Austria by Nazi Germany, 1938. March

${ }^{40}$ Endre Gelléri Andor (1907-1945) writer

${ }^{41}$ Andor Németh: A szélén behajtva. Budapest.1973. Magvető.
} 
Because of the advance of Nazism and the Jewish Laws, ${ }^{42}$ Petö went to Paris. He occupied himself with vague business affairs and enjoyed the night-life of Paris. He often got together with the Hungarians living there, for example with the writer Béla Zsolt. ${ }^{43}$ Németh followed Petö's advice and started to research the sources of Liebermann's life and work. He wrote about this:

I spent my mornings in the Bibliotheque Nationale and read a cabalistic book to which Petö had called my attention. It had been published sometime in the first half of the nineteenth century. It was a strange and forgotten book but fortunately I found it. I learned a lot from it, which was beneficial not only for my book. ${ }^{44}$

Pető returned from Paris in 1939. We know only a few episodes from the period of war. For example:

In Pest during the anti-Semitic laws he had a girl-friend who directed a textile factory. They met daily and Petö gave her advice on how to run the company. He was a self-governed, independent individual. ${ }^{45}$

Pető spent Hungary's almost year-long period under German occupation, from March, 1944, in the Children's Home of the International Red Cross, in Orsó utca in Budapest. He found shelter there with the help of his psychiatrist friend Miklós Kun ${ }^{46}$ who worked as a member of the Red Cross medical unit at the shelter. Since Petô could not bear wearing the compulsory yellow star which stigmatised and separated Jewish people from others, he never left the house. Born ${ }^{47}$, leader of the International Committee of the Red Cross, acting in conjunction with JOINT ${ }^{48}$, wanted to get papers, food and medicine to those hiding or living in the ghettos in Budapest, mostly without success. On the advice of the Zionist Movement, Born organised a separate group called Section A in which two hundred and fifty people worked under the direction of Ottó Komoly ${ }^{49}$ Their task was to place abandoned children in almost thirty children's homes, run and supply these institutions with food and organise medical units for them all. The other group, Section B, belonged to the Good Shepherd Committee. The merciless persecution of Jews began after the Arrow-Cross Party seized power in October $1944^{50}$. The number of orphans grew excessively, the mothers and fathers deported or dumped into the Danube and the babies left in baskets with begging notes at the gates of children's homes, waiting to be rescued. This is how Miklós Kun recalls those times: ${ }^{51}$

\footnotetext{
${ }^{42}$ First Anti-Semitic Law, 1938: the set percentage of Jewish people in the media, in engineering and in the chamber of lawyers was not to exceed 20\%. Second Anti-Semitic law, 1939, the proportion of Jewish people partaking in economical and social life was not to exceed 6\%. Third Anti-Semitic law, 1941: the right to wed in accordance with the Anti-Semitic laws of Nürnberg.

${ }^{43}$ Béla Zsolt (1895-1949) writer and publicist

${ }^{44}$ Andor Németh: A szélén behajtva. p.686. Budapest. 1973. Magv

${ }^{45}$ Interview with Dr Miklós Kun

${ }^{46}$ In the Saturday saloon of Miklós Kun the intellectuals of Budapest met: writers, poets and artists: Miklós Radnóti, György Bálint, Milán Füst and the young György Aczél, etc. In the interview with Miklós Kun from 1988-89. Oral Archives of the 1956 Institute. No 188. p.81.

47 Friedrich Born (1903-1963) delegated member of the International Committee of the Red Cross to Hungary in 1944-45.

${ }^{48}$ JOINT Jewish aid organisation, which was founded in the USA during World War I. for aiding the victims of the war. It became an international organisation during World War II. It operated actively in Hungary until its closure in 1953. Since the change of regime in 1989, it once again operates an office in Budapest.

${ }^{49}$ Vaada, Zionist Aid and Saving Committee created in 1943. Partakers in this founding were Joel Brand, Kasztner, Springmann, Ernő Szilágyi and Ottó Komoly. In Randolph Braham: Hungarian Holocaust. Budapest. 1988. Gondolat.

${ }^{50}$ Arieh Ben-Tov: Holocaust. Budapest. 1992. Dunakönyv. p.195.

${ }^{51}$ Interview with Dr Miklós Kun.
} 
Then came the Arrow-Cross regime. The International Red Cross where I was senior doctor had a B Section was really a representation of the JOINT. I heard of Auschwitz in the spring of 1944. I had an acquaintance, Miklós Klein, who worked at the Swiss Embassy, and he told me there were records and that someone who escaped from there wrote down what was happening in Auschwitz. That was when I had the idea to establish children's homes, to save the children at least. It was similar to what Margit Schlachta did to save children. I went everywhere, I went to the Swedish embassy, to the Papal Nunciature and to everyone else but nobody wanted to talk to me, they said the time was not right. Finally I was advised to go to the Zionists. I contacted Ottó Komoly, ${ }^{52}$ the leader of the Hungarian Zionists, and he told me to look up the B Section of the Red Cross. That was when I started to organise the children's homes.

It was in the children's home in Orsó street that Petö started to work with sick, disabled and motor-disordered children, using the movement therapy which he had already successfully used in pneumological and psychiatric institutions. ${ }^{53}$ This home, however, could not guarantee complete protection to those living there. ${ }^{54}$

Ágnes Kenyeres recalls Petö's period in hiding: ${ }^{55}$

In March 1944 the Germans had already taken over. Petö couldn't move around freely as then the yellow stars had to be displayed, although he never actually wore his. I knew someone was taking care of Petö, I mean they were hiding him... So, all I knew about Petö was that he was in a relatively safe place. Later I heard from him that the man who was hiding him in his apartment was on Margit Bridge when it was blown up full of vehicles and people. The man died in the Danube and Petö was left in the locked apartment. His escape, survival and staying alive are simply a miracle. He said only that it was his friend Miklós Kun who rescued him.

\footnotetext{
${ }^{52}$ Ottó Komoly, President of the Hungarian Zionist Union, engineer. The Union had a threefold goal, to save Jewish lives across the border, to support refugees and to prepare the self-defence of Hungarian Jews. R.Braham: Hungarian Holocaust. I. 91. p. Budapest,1981. Gondolat

${ }_{53}^{53}$ Interview with professor Péter Popper.

54 '...At 1.30 am, December 6th, 1944 somebody rang the door bell to the Orsó u. Children's Home, which was under the protection of the Spanish Embassy and the International Committee of the Red Cross. Three armed Arrow-Cross soldiers demanded from the civil defence officer to be let in. The officer showed them the sign indicating the immunity of the house and that it was out-of-bounds. The three Arrow-Cross men destroyed the signs and entered the building aggressively. In the bedrooms they made everyone undress, they searched their pockets and took everything, they then insulted some of the people and left.' Arieh Ben-Tov: Holocaust. Budapest. 1992. Dunakönyv. p.211

${ }^{55}$ Interview with Ágnes Kenyeres.
} 

At the beginning of the twentieth century carefully planned and constructed exercises taken from movements used in everyday life were put into practice in healing. These consisted of conscious muscle- strengthening and relaxing exercises and mechanical exercises. Hungarian physiotherapy training is associated with the name of Alice Madzsar (1875-1935) who opened the Teacher's Training College for Functional Exercises in 1912. Through her method of correctional gymnastics she strove for 'muscle consciousness.' She created energy through suggestion and achieved results by alternately relaxing and energising muscles. During the exercises very few clothes covered the bodies of the participants so that movements could be clearly seen. Petö's young patients on the threshold of puberty often felt very awkward during mixed-sex demonstrations when this method was used. ${ }^{56}$

Pető had to struggle against the fossilised doctrines of the Hungarian special-education system. Provision was made according to four categories:

a) those whose emotional life differed from the norm (emotional dissimilarity, total withdrawal from society, unconstrained and antisocial behaviour);

b) those who were mentally disabled;

c) those with low learning capacity;

d) those unable to be educated and treated in normal schools. ${ }^{57}$

Gusztáv Bárczi (1890-1964) was the decisive figure in Hungarian special education. He had completed a special education course in 1913 and later started his medical career as an otologist (ear specialist). He worked to improve the speech of deaf-mutes, forming human communication, integrating patients into society and improving their intellects. ${ }^{58} \mathrm{He}$ and Béla Török, ${ }^{59}$ an otologist well-known in Europe (György Békésy ${ }^{60}$ made him the first Hungarian audiometer), founded the Institute for the Hard-of-Hearing ${ }^{61}$

In 1937 Bárczi became Director of the Alkotás street Institute for the Handicapped, on the site of the Institute for the Mentally Handicapped founded by Jakab Frim in 1875. From then on he worked in the education and upbringing of mentally handicapped people. In 1944, during the war, many Jewish children found refuge there. After the war he began rebuilding the ruined Institute and school education, with great dynamism.

After the war thousands of rootless orphans wandered hungry, cold and sick through the shot and bomb-torn city. It posed a huge problem for the political leaders responsible for accommodating these children. ${ }^{62}$ Miklos Kun recalls:

\footnotetext{
${ }^{56}$ Interview with Dr Katalin Hidvégi.

${ }^{57}$ József O. Vértes A magyar gyógyító pedagógia 1848-ban és ma In A köznevelés évkönyve ed. by Á. Kiss. p. 264. Budapest. 1948. MVKM

${ }_{58}^{58}$ He gave named new clinical picture (subdomutatis corticalis).

${ }^{59}$ Béla Török (1871-1925) otologist

${ }^{60}$ György Békésy (1899-1972) Hungarian physicist and Nobel Laureate, lived in the USA. He investigated the physical regularities of acoustic and hearing problems.

${ }^{61}$ Gábor Palotás, Dr Gusztáv Bárczi. Orvosi Hetilap. Volume 133. Issue 14. pg. 963

62 'There were street-boys and abandoned children among them, whom we found like this. Once in a train we found 30 35 children. They had identification sewn on to their clothes, such as 'Said to be Sándor Szabó, supposedly eight years old.' They had been locked in the train for five or six days without food or drink, and nobody knew where they had come from, nor where to they were supposed to go, or why they ended up in a cattle trucks.' Ferenc Gáti, Remembering the decades of domestic children's and youth welfare after the liberation. Gyermek és ifjúság védelem 1986.Vol. I pp. 34-35.)
} 
Later, after the war, there were huge arguments concerning the protection and welfare of children. We wanted to place them with families but in Party circles they were against this type of care. Our greatest problem was the infants. With my friend László Dobszay, who was President of the Foundling Hospital in Pest, we placed the infants with child-loving women who owned flats, whom we found through advertising in the newspapers. We checked and prepared them for bringing up the children. This kind of community care system worked really well, until one fine day Anna Ratkó ${ }^{63}$ sent for me and said: 'Comrade Kun, you are supporting the bourgeois' and listed the names of the wife of a Lord Lieutenant and of a Chief Counsellor whom we had trained. I told her we were not supporting the bourgeois but saving proletarian children, that those people owned flats and we were not going to place the children in one-room proletarian flats. It was an ideological problem and I was even reported to the police because in the Home for Juvenile Criminals in Rákospalota, opened by Mrs Mihály Károlyi ${ }^{64}$, there were pictures of saints hanging on the walls, ${ }^{65}$ I went out there to see them: they were Renaissance pictures. Works of Botticelli and of other great artists were hanging on the walls. ${ }^{66}$

Also after the war Petó wished to improve the condition of motor-disordered people by some method which would make treatment possible even in the then prevailing circumstances (lack of medicine, specialists and instruments). That is how he became interested in movement therapy. Treatment of children and patients with paralysis, hyperactive and spastic, was the task of the Institute of Special Education directed by Gusztáv Bárczi. Petö arrived with his ideas at the best time. Bárczi who was also the Director of the College of Special Education did not need to be persuaded about the effects of movement therapy since it had been used for a long time with blind and hearing-impaired patients. In the College's Therapeutic Laboratory, directed by the famous Lipót Szondi, ${ }^{67}$ Lucy Liebermann Pátzai ${ }^{68}$ and Adolf Sulyomi Schulmann had been using motor education and motor tests, particularly with speech-impaired patients, back in the 1930s. The Methodology of corrective motor education had already been written. Lucy Liebermann taught motor education. But movement therapy, as was being suggested by Petö, addressed a new target group and offered a new possibility for the College.

After learning of Petö's work Bárczi persuaded the higher authorities to accept it and founded a Movement Therapy Department with an outpatient department for fourteen patients. László Focher, the neurologist from the State Home for Destitute Children, picked out the most serious and hopeless cases for Petö ${ }^{69}$ who commenced his hard task fanatically, working out his method and its practical implementation. He began this work in very adverse circumstances.

\footnotetext{
${ }^{63}$ Anna Ratkó (1903-1981), Minister of Health 1949-53. The first female Minister

${ }^{64}$ Count Mihály Károlyi (1875-1955) democratic, liberal politician. President of the Hungarian Republic in 1919. He shared out his land. He returned to Hungary after the Word War II. He is referred to as the Red Count. His wife, Katinka Andrássy, shared the liberal democratic and anti-fascist ideals of her husband.

${ }^{65}$ Remembering the decades of domestic children and youth welfare after the liberation. In Children's and Youth Welfare 1986. 1/31-33.

${ }^{66}$ Interview with Dr Miklós Kun.

${ }^{67}$ Lipót Szondi (1893-1986) neurologist, psychiatrist and leader of the Biological and Pathological Institute of the College of Special Education. He left Hungary in 1943 because of the prosecution of the Jews. He went to Switzerland and to America. He founded a new school of depth psychology called 'faith analysis'. His tests of instinct diagnosis are used in psychiatry.

${ }^{68}$ Pál Páczay (1896-1979) sculptor

${ }^{69}$ András Pető: Conductive Movement Therapy as Special Education. Gyógypedagógia, 1955 Vol. 1, pp. 15-21 (Annotated and abridged version by A. Sutton in The Conductor, no. 18, 1993, pp. 37-39.)
} 
In Budapest after the war there were hardly any windows left intact and the buildings were all damaged. There was neither electricity nor water supply. Pető obtained two rooms in the Institute, with a corridor where they even had a bathtub which they used not only for bathing but also for washing up..$^{70}$ In the starving capital the children in the Institute got so-called Truman Frankfurters which was made of soya beans and were named after the American president. The children's food and the Institute's expenses were defrayed from grants given by the American JOINT. They could not afford to pay Petö a salary and for three years he worked without payment.

Pető's movement therapy included physiotherapy, exercise therapy, breathing therapy and movement education. Bárczi expected the following from the new department:

This is not just about co-operation between doctors and special teachers but the students of our college as well as medical students will receive training in, among many other things, the after-care of polio and cerebral palsy. From this department we expect that, within the framework of a uniform treatment, the effects of a homogeneous, methodical and group education will bear fruit. ${ }^{71}$

Petö started work using his method with residential children believed to be incurable and after one year a commission reported that the condition of the children had improved remarkably. The news spread and they began to treat outpatients as well as residential children. The method needed a long time to show effects. Dr Palotás speaks about this:

Rehabilitation is never as quick and visible as an aching ear which throbs at night: the child has a fever, everyone is excited and desperate and then the doctor comes and lances the infected eardrum, the fever goes down, the pain is gone and the worried mother calms down. That is a simple, mechanical intervention. The suffering is over, everyone is happy - that is the reward. It is not like this with children who have motor disorders. Rehabilitation is a slow process. Only someone who is completely committed can do it. There is not the same kind of reward as with an infected ear because there is no full recovery. Parents of course want this for their children. There was always some sort of a miracle. With rehabilitation, if the lessening of suffering is achieved through long and arduous work, then that is considered a great result. $^{72}$

Ilona Székely remembers working at the Institute in those early days: ${ }^{73}$

It was 1948 and a group of children in state care arrived at the Institute of Special Education. My husband worked for the Institute, he was the odd-job-man there: he heated the building, took the washing to the laundry, re-glazed the windows, tidied the garden and so on. We didn't have a flat; I stayed in the garden of the Institute with my baby daughter ${ }^{74}$. Peto told my husband to bring his family inside, and they would make a flat for us. My husband carried the coal out of the cellar and made room for us there. Ildi, my daughter, was ill. At Christmas Bárczi invited us up to the schoolrooms as all the children had already left for the holidays. Bárczi said:

'Come on, girl, let's go to the first floor. For the time being you'll get a room and we'll put in an iron bed for you to sleep on.'

\footnotetext{
${ }^{70}$ Mária Hári: The history of conductive education and its concepts. First World Conference of Conductive Education 1990 MPANNI p.11.

${ }^{71}$ Gusztáv Bárczi, Magyar Orvosi Szemle 25th February 1948.

${ }^{72}$ Interview with Dr Gábor Palotás

${ }^{73}$ Interview with Ilona Székely.

${ }^{74}$ Ildikó Székely Kozma, was the one of a director of the International Pető Institute
} 
Then Bárczi drew a Christmas tree on the blackboard with coloured chalks and said: 'You should have your own Christmas tree. He touched my daughter and realised that she had a fever. Bárczi - I have respect even for his memory - stated that it was otitis and talked to Petö (I only learnt about this later) and they got penicillin for my daughter, which was an almost non-existent treasure at that time. My daughter recovered very soon after that.

A few days later I met Petö and he told me to take my daughter out in the fresh air every day from then on. Ildi couldn't walk yet, she was only ten months old. Before that I had seen Petö every day, I always greeted him but he never said hello. But then one day Petö was walking there and I greeted him, and he stopped and asked:

'Do you have no other work than this one child?'

'No, I don't, Doctor Petö,' I said.

'Well then, come in to me, I'll give you work.'

'But where am I going to put my baby?'

'Bring her in,' he said, 'or solve it however you can.'

In the Institute there were more and more children and the number of the adult patients also grew. There were many possibilities for work with the children. Mrs Székely began her work with Petö: ${ }^{75}$

On the first floor there was a room where the patients lay on wooden pallets. In the big room, where the children were accommodated, there was a cage with parrots in it given by someone. Above it a picture of Rákosi, ${ }^{76}$ underneath sat Petö. These two bald heads were rather strange and made me laugh. My work was that, if one of the nurses, Matild, told me that a child had to go to the lavatory, then I had to pick that child up and take and put him on the potty. This was my work from morning till evening. There was one severely mentally handicapped girl. Usually I had to take her. Once it looked like Petö was watching me when the girl was in my arms, she had a cold, her nose and everything were running. I thought 'Why should I always wipe this child's nose?' and said 'Come on, Hetty', Heather was her name, 'let's hold this hanky together!' She looked at me a little bit dully, presumably nobody had ever asked her such a thing of her, but I held her hand and we wiped her nose together. I praised her. Then Petö called out to me:

'Would you stop for a minute, please, you'll amount to something one day! From today on you won't carry a single child again. You will lead the children in a way that you'll stand face to face with them or they will push a chair in front of them. And teach them to wipe their noses.'

Well, from then onwards we could only help them in dressing and showing them how to do things. They had to work with us, which meant not instead of them and not with them but leading them, working together. I had no idea then that this was a method.

Júlia Dévai, who was a young student at the time, remembers it like this ${ }^{77}$ :

At this time Petö's students were his co-workers as well. We were all recruited by János Werkner from the second class of the Medical University of Budapest. After about two or three months of listening to our excited discussions, about our important and real work, with this fantastic man in a fantastic world of effort, pain and wonders, Mária Hári wanted to belong to this privileged group too. We got her in only after some difficulty but at the end her endless devotion, her frugal needs and unbelievable persistence got her a special position with Petö.

\footnotetext{
${ }^{75}$ Interview with Ilona Székely.

${ }^{76}$ Mátyás Rákosi (1892-1971) President of State (1949-1953) leader of the Hungarian Workers Party, symbol of the Hungarian way of Stalinism

${ }^{77}$ Recollections of Dr Júlia Dévai (1913-2015)
} 
In 1947, as a result of our persistence in facing and fighting bureaucratic difficulties, Petö finally got a far from large place in one of the old buildings of the Teachers' Training College for Special Education, and at last he could start to think about moving his treatment centre from Stollár Béla utca to a move appropriate place. At that time the Director of the College was Professor Gusztáv Bárczi, a broad-minded intellect for his time. He wanted to adopt the Petö method as a part of special education, which suited Petö fine on one side but on the other he did not wish to become part of any established field. Thus their relationship was not one without distraction.

The place Petö got consisted of four rooms on a broad corridor and a small cubicle under the stairs. After acquiring two lab stands, one small alcohol burner and four bottles of chemicals, the cubicle was referred to as 'the lab', where the later Director Márika Hári's career started. Beside the 'lab', there were two dorms, a big treatment room, and an office for Petö.

Since Petö got only empty rooms, we all worked hard in getting together at least some meagre furniture. The war was hardly two years over and supplies were scarce. Hearsay was the only source for finding the necessary furnishings. A friend knew about an abandoned store room where one could find a few hospital beds with black iron springs. Another brought news about some old mattresses in a cellar. A Swiss trade union called CGT donated one pillow and two grey soldiers' blankets per bed, and also gave some bed sheets, pyjamas, and nappies. The head of that organisation in Hungary at that time was a certain Toni Drittenbass, who was later imprisoned by the Communists as a spy and gave birth to her baby in a Hungarian prison. Shoes, socks, and underwear were provided by the Red Cross.

The whole bathroom consisted of one small basin, one tin bathtub and one cylindrical water heater using lots of wood for a small amount of water. The equipment was donated by one of our classmates from the university, who was working in his own tinshop to support himself through the university years. We used the tub not only for bathing the kids but with some modification, it also served as our dishwashing facility. In the treatment room we had three berths put together by a carpenter who was a concentration camp survivor. Because of the general post-war poverty, the carpenter had only fragments of timber, broken logs and boards, thus he could not make a bench with a nice smooth surface. He created something called a "priccs"78. It was the prototype of what is the obligatory Peto" bed today. He said he got the idea from the concentration camp and, he added with good-hearted self irony, if these berths were good enough for the prisoners, they would surely be OK for some young crips.

We wanted Petö to have a decent office, so we went to a fleamarket on the other side of the city. We bought him a desk, a chair and even a beautiful Persian rug. As it turned out later, the original motif of the old carpet was just painted on a mat. He had Van Gogh's reproductions on his walls, probably still missing from somebody's album.

We also had to think about some clothes for the future patients. So my husband, who had good connections with the storage manager of a big textile factory, got two huge bales of red and blue chequered cotton with some printing errors in them. Mr Bárczi knew about a sheltered workshop where people with intellectual handicaps were sewing. The garments they produced were definitely not haute couture but this surely determined the style, the colour, and the cut of the clothing that would be worn in the Petö Institute for many years to come.

By Christmas of 1947 everything was ready for us to take the first inpatients. We thought it would be easy to find kids in need of this new kind of motor training but the opposition on the

78 Priccs - Pritsche is a German word an uncomfortable, hard plank bed (eg in prison, army base, in barrack) 
part of the medical society was strong. The orthopaedic surgeons resented that Peto's method lacked both surgical solutions and the use of technical support aids. Neurologists did not believe in any form of therapy for children with cerebral palsy. Thus all Petö could get was a group of thirteen kids from the neurological department of an orphanage (today it is the Pál Heim Children's Hospital), all of them with severe conditions: athetotic, spastic, hypotonic, quadriplegic, hydrocephalic and spina bifida patients, and a few polio-stricken kids, between the ages of six and twelve. One of the departmental heads at the orphanage could not suppress a demeaning and somewhat ironic smile while he assigned the most hopeless cases to Petö: if he is really so big with his new fancy method, he should demonstrate it on these kids!

We stood shocked and numb in the huge ward. The kids were lying in crib-like beds, with almost no clothes on, just turning their heads back and forth and making monotonous noises. They were undernourished, dirty, and sad. We hired two taxis, covered the kids in blankets, and took them to our new place where everything smelled of fresh paint. We bathed them, gave them new clean pyjamas and fed them. The food was brought from a nearby kitchen for mentally retarded kids. For two years it was a basic diet. Whatever was available on the empty post-war market served as their food, in contrast with any dietary need, dried peas, beans, cabbage, grit. We had milk and bread too, and sometimes we got cheese or a piece of bologna. We almost never had meat. Petö prescribed certain vitamin sources to add, like sour cabbage, codliver oil, yeast and carrots. Later, in spring we could get some vegetables and sometimes fruit too. The kids felt they were in heaven: they were clean and warm and well fed. Small details never disturbed them, like we never had enough chairs, and the tables on the corridor served for dining, writing, learning, playing, and everything else. But we had paintings from Piroska Szántó, and other original pieces of art donated by Petö's friends, making the whole, basically dreary place somewhat more humane. Petö wanted more than that the kids should just feel happy and at home, he wanted something to happen to them as soon as possible.

At the beginning uneducated girls provided all the support and care the kids needed. They ate with the kids, they slept in the same room, they sang and played together. The girls had no home outside this small place, kids and caretakers all shared the same life. Petö was instructing not only us but these girls as well. They were the forerunners of the sophisticated conductors of later days, who would be required to have high-school graduation and a successful entrance exam before they could even think about setting foot into the Petö Institute. But at the beginning all Petö wanted was a good, absorbing head, a good, attentive heart and lots of committed hard work.

Petö observed every child closely and, based on these observations, he compiled individual series of exercise. He regularly controlled, corrected and improved these series. Originally, there were two individual, one-hour-long sessions daily and it happened only later that during individual sessions work began in groups. His attitude toward the kids was a kind of strong suggestion: 'I know you can do that!' He spent hours with the kids experimenting with new solutions, new tasks. He was very open-minded, and was always ready to refine his method. He demonstrated everything with his own body, quietly counting or rhythmically speaking the text to enhance concentration. He kept his eyes closed but there was no tiny detail escaped his vision. The strength of his personality was tremendous. The kids simply got attached to him and tried to do their best just to please him. We did the same and tried not to miss any of his sentences, murmurs, or moves. We wrote down his first series of exercise, and tried to repeat them with the kids exactly the same way he did. There were no written textbooks on conductive pedagogy because there was no conductive pedagogy. It was born and created in front of us. The first written form was a twenty-page-long workbook for special-education students, put together by Petö and myself. 
As the time went by, more and more families turned up with their physically handicapped children because it was the only place in the country where something effective was happening. In many cases family members also got interested and involved in the work, thus more and more individual and group sessions could be provided. During this period, the typical Petö daily schedule was formed, exercises, sing-along, meals, rest. Later, learning and play filled the days in a regular rhythm and everything became part of the whole treatment. The intensity of this program brought early results in these previously untreated children. Even experts from abroad paid attention to these unexpected results.

According to a survey in 1947 the special education network was as follows: ${ }^{79}$

\begin{tabular}{l|l|c}
\hline \multicolumn{2}{c}{ Institutions } & 1 \\
\hline I. & Institute for the Handicapped & 2 \\
\hline II. & Department for paralysed patients & 9 \\
& Homes for the deaf and dumb & 1 \\
& Technical-occupational centre for the deaf and dumb & 2 \\
& Homes for the blind & 3 \\
& Supporting and occupational institutions for the blind & 1 \\
\hline III. & Institute for the speech-impaired & 1 \\
& Special Education Institute & 1 \\
& Occupation centre & 332 \\
& Schools & \\
\hline
\end{tabular}

\begin{tabular}{l|c|c}
\hline \multicolumn{1}{c}{ Condition } & $\begin{array}{c}\text { Children } \\
\text { of school age }\end{array}$ & $\begin{array}{c}\text { Children } \\
\text { attending school }\end{array}$ \\
\hline deaf/ dumb & 1,103 & 738 \\
\hline blind & 394 & 213 \\
\hline imbeciles & 2,826 & 1,308 \\
\hline crippled & 518 & 118 \\
\hline
\end{tabular}

Petö filled a gap in the field of treating disabled people. Patients arrived from all over the country, inpatients and outpatients, children and adults. Béla Biszku recalls the time ${ }^{80}$ :

One of my former classmates, Károly Szamosi, who worked for Népszabadság ${ }^{81}$ as a Deputy Editor suggested that I should go to Petö. He told me how he had come into contact with Petö. After the war, in 1945, Szamosi quite suddenly became paralysed, literally from one

\footnotetext{
79 József Vértes O.: Hungarian Special Education in 1948 and today. A köznevelés évkönyve ed. by Á. Kiss p. 266. Budapest 1948. MVKM

${ }^{80}$ Interview with Bela Biszku

${ }^{81}$ Népszabadság (1956-2016): The central paper of the Hungarian Socialist Workers' Party (MSZMP) and since 1956 the successor of the defunct Szabad Nép. The editors were nominated by the MSZMP Central Committee.
} 
day to the next, and although he was taken to lots of doctors and from one institute to another his condition didn't improve. He was walking with the aid of two crutches and had a kind of machine on his legs when he was told to go and see Petö because he might be able to do something. So he was taken to see Petö in Alkotás utca. As soon as Petö saw Szamosi he shouted:

'Take away those sticks and take off that machine, you murderers!'

Szamosi had such a fright that he dropped the sticks and, although his muscles and hips were already weakened, the machine was taken off his legs. This was his first meeting with Petö and after that Petö started work with him. Petö stated that the cause of the paralysis was the side-effects of medication. Although Szamosi had been taken to dozens of doctors, none of whom could diagnose the cause of the paralysis, Petö had only to look at him and immediately knew the reason.

Petö become more and more popular and successful among patients, but his official acknowledgement or appointment happened only in 1948, before which he was not paid. Ágnes Kenyeres remembers it like this ${ }^{82}$

In the autumn of forty-five I had started working at the Ministry of Housing, through the Bourgeois-Democratic Party where one of the movers and shakers was Gábor Kemény. He was organising a Department for Educational Affairs and he invited me to be an official there. Later Dezsö Keresztury ${ }^{83}$ became Minister but the winds of change were already blowing. Then came Ortutay ${ }^{84}$ from the Smallholders' Party, with whom we were good friends since my husband's company published his collection of ballads. Our circle of friends consisted of young people from the town of Szeged, and till forty-eight, while Imre my husband was still able to sit up, I was always inviting people to our home. In the Ministry of Culture I worked with Fifi, a good friend of mine from our childhood, who was the widow of the great Hungarian poet Miklós Radnóti. During the war Radnóti was taken off to Nazi forced labour. In our last conversation together while visiting their home after we had been to a concert, Radnóti had asked us to take care of his wife, Fifi. Radnóti was killed in the war and buried in a mass grave. We met Fifi again only after her husband's exhumation. Once she fell ill and couldn't swallow or couldn't salivate but she went to Petö and he treated her successfully.

So Fifi started mentioning Petö. I said I would go to him as well, breaking a silence of two years. Petö was extremely understanding, I cannot put it any other way. He even hugged me though he was not that type of a man and somehow his movements were such as if he were telling me not to mention the whole thing at all. He asked me how Imre was doing. We agreed that the Polish doctor was a charlatan. So in this way our connection to Peto was picked up again. He told us about his life after forty-five, how the group of doctors around, Simonovits ${ }^{85}$ was very much against him. They were questioning whether Peto even had a degree in medicine. I don't know when his connection ceased with the Institute of Special Education, where my husband had once been treated for three months. He was persecuted from all directions; he had enemies, terrible people. I do not know many names, I remember Simonovits because Petö mentioned him so often but there was a whole group behind him who made Petö

\footnotetext{
${ }^{82}$ Interview with Ágnes Kenyeres

${ }^{83}$ Dezső Keresztúry (1904-1997) teacher, writer, poet, translator of literature, Minister of Culture, Education and Religion 1945-1947

${ }^{84}$ Gyula Ortutay (1910-1978) ethnographer, collector of folk-tales, museum director, Minister of Culture, Education and Religion (1947-1950), Deputy Chairman of the Cabinet (1963-1965)

${ }^{85}$ István Simonovits (1907-1985) Under-Secretary of State at the Ministry of Health
} 
sound like a witch doctor. This is when he conceived of the idea that he had to found an institute for movement therapy, this is when it all started.

The great reformer of the health system, Professor of Radiology Zoltán Zsebök, ${ }^{86}$ writes about Petö's appointment in the following way:

Let me explain a few unique tasks of mine, which needed to be resolved. On one occasion Gyula Ortutay's secretary, Fifi Radnoti, rang me, saying that she would recommend a colleague of mine, Doctor Petö, to my kind attention, who could do remarkable things with disabled children to improve their motor skills. I wouldn't be being honest if I said that he made a good impression on me. When he took a place in my room, he seemed almost boneless. When he sat down, he collapsed like a sack. After he started speaking, I thought at first that I was talking to a dreamer but even so he held my interest and when he explained his plan, which seemed to be quite risky, I trusted him. I didn't have any prejudices and I thought that the best thing would be to give him a small scope of action. We appointed him to an appropriate position to be able to start work. The Institute, which later became well-known, was born out of this initiative, where my colleague Petö worked with his original and unique methods and helped many disabled children in need in a way which seemed little short of miraculous. ${ }^{87}$

\footnotetext{
${ }^{86}$ Zoltán Zsebők: (1908-1984). Professor of Radiology, Secretary of State for Health.

${ }^{87}$ Zoltán Zsebök: Lépcsőfokok, Budapest. 1981. Szépirodalmi Könyvkiadó pp. 305-306.
} 



\section{POLIO}

Petö was appointed to his post retroactively. One reason was the enormous number of children paralysed by the two-yearly Heine-Medin epidemic. The number of paralysed children rose drastically. Conventional medical science failed, which left Petö and his method. The hopeless cases were given to Petö as a kind of experiment.

In 1946-47 there was a terrible epidemic of Heine-Medin in Europe. In Denmark all medics were called in to help with the artificial respiration of the paralysed. In 1957 there was another Heine-Medin wave here. This is when the Children's Hospital of Buda got startedwhere the Party kindergarten used to be. All the infected children were brought there. Mrs Lukács was behind this, the wife of Lukács the orthopaedic doctor. The other epidemic hospital became the Pál Heim Hospital, which used to be a children's home and before that an orphanage. In America during Roosevelt's time, enormous government support was given to those infected with the polio virus, because the President himself had suffered from the illness in his childhood. Later, with the discovery of vaccinations, those kinds of illnesses disappeared almost completely. Instead of them, the Little epidemic was taking its victims. ${ }^{88}$

\begin{tabular}{|c|c|}
\hline \multicolumn{2}{|c|}{ Poliomyelitis $^{89}$} \\
\hline Year & Paralysed children $^{89}$ \\
\hline 1938 & 302 \\
\hline 1949 & 298 \\
\hline 1950 & 257 \\
\hline 1951 & 310 \\
\hline 1952 & 500 \\
\hline 1953 & 313 \\
\hline 1954 & 1176 \\
\hline 1955 & 617 \\
\hline
\end{tabular}

During those times even health statistics were a state secret so, for the number of HeineMedin patients in the years from 1948 to 1955 , we could rely only on the figures given in the Statistical Yearbook. According to doctors, however, the real figures were much higher than the official ones, which might reflect deliberate whitewashing.

Tamás Vekerdy recollects Pető's successful treatment. ${ }^{90}$

Petö treated motor-disordered people with poliomyelitis and other symptoms, especially those officially registered as having no chance of improvement. At first to the amazement of official Hungarian medical circles and then to their annoyance, he successfully treated and even cured such patients, enabling them in almost all cases to carry on a normal life after his treatment. 'I see it but I don't believe it,' stated the university professor charged with investigating Peto"'s work by the Health Council, when a patient with a fractured vertebra stood up and stared to walk.

When Petö was examining a despondent young woman, a victim of the Heine-Medin disease who could only walk with the aid of a gaiter, he asked her:

\footnotetext{
${ }^{88}$ Interview with Dr Gábor Palotás (1927- 1993.

${ }^{89}$ Yearbook of Statistics 1949-1955. Budapest 1957, KSH 316

${ }^{90}$ Tamás Vekerdy, Álmok és lidércek, Budapest. 1992. T-Twin
} 
'What would you like?'

'I'd like to walk!'

'And you shall walk.'

'But I want to be able to walk without the gaiter!'

'You shall walk without the gaiter'

And the gaiter really did end up in the storeroom two weeks later, where it joined a pile of others discarded by other patients. And a few months later the young woman was walking unaided:

'But I want to be able to walk down the hill into the city,' the young woman said demandingly to Petö (she lived in the Széchényi Hills).

'And so you shall' he agreed and not long afterwards the young woman was able to walk down the hill.

His results were undeniable but his method of achieving them was not elucidated according to 'modern medical science'. The wooden-headed men of the middle ranks of the Ministry of Health, the jealous colleagues, professors and practising doctors, prepared a proceeding against Peto" and his colleagues: they wanted the Institute shut down. 'He is a charlatan,' they said, 'what he is doing is unworthy of the Socialist science of medicine.' Rumours and gossip spread, according to which Petö did not even have a degree, he had failed to finish the University of Medicine in Vienna.

The two rooms in Alkotás street, from the early days, were soon too small. At first the Institute was extended a little with more rooms put at Pető's disposal where he treated both bedridden patients and outpatients, so-called ambulatory cases:

Many outpatients have arrived. In the early morning mothers push their paralysed little ones in small tricycles or in wobbly prams through the gate of the Movement Therapy Institute at No 53 Alkotás street. They were brought here by the after-effects of polio and by paralysing neural spasms. Inside, eight rooms open off the narrow, dark, tiled corridor: fifty-four lucky patients can live and be treated here. There is no more room for others because the young, two-year-old Institute has already outgrown its initial accommodation. ${ }^{91}$

The Institute had already won recognition abroad, with patients coming from England, Romania and Bulgaria. By doing his utmost and using his connections to the fullest extent, Petö managed to get his Institute rebuilt on the gently sloping downs of Villányi street, still at that time covered with vineyards. The actual construction dragged on for a long time, partly because of the bureaucracy of the period and partly due to debates about financing. Petö fought hard for quicker and cheaper construction methods because

...our Institute is not in point of fact a hospital and therefore all the special types of construction and special equipment necessary for a hospital are not required here. The only important thing is that the Institute be built quickly and cheaply because a whole range of such institutes will be necessary covering the entire country ${ }^{92}$.

\footnotetext{
${ }^{91}$ Szabad Nép - weekly paper. 23. June 1949.

92 Ibid.
} 
Ágnes Kenyeres tells: ${ }^{93}$

Though without any great power, I stood behind him completely. Zoltán Zsebök ${ }^{94}$ of the Smallholder's or Peasants' Party was Under-Secretary at the time and I asked him to support Petö. Fifi carried the Ortutay line completely, and in this way the building of the Institute started. That the Villányi ut Institute was born was due not just to my participation, it was due to Fifi's as well. There were financial problems and all sorts of other affairs, I don't remember all the details, but we had to fight in meetings if money was needed. The Institute was created around the end of the decade.

Károly Ákos, however, thinks (though he is not certain whether this is true) that it was he who unintentionally arranged for Pető to obtain the Villanyi út premises. Ákos had been to Ilona Kolcza who was at that time trustee of an Unitarian fund based in Switzerland. Ms Kolcza was a Communist and had been a member of the underground Communist Party. Ákos knew her because he edited the newspaper of the medical Trade Union and had been told to meet her because she was an interesting person. At that time he talked about Petö to everyone he met. Anyway, the fact is that Petö obtained his institution. $^{95}$

The Institute opened its doors on 22 February 1950 and Pető was appointed the following day. In his curriculum vitae he recounts as follows:

In 1947 I became a teacher in the Movement Therapy Department of the Teacher Training College of Special Education and at the same time I was appointed Director of the Movement Therapy Ward at the Institute of Special Education. Out of this ward the Movement Therapy Institute of the College was born, which later became the National Movement Therapy Institute. I was named Director of the latter on 23 February $1950 .{ }^{96}$

Mrs Székely remembers: ${ }^{97}$

There was no such thing as fixed working hours, we worked from morning till evening, especially those who lived in the Institute. My daughter slept on a pallet, and I also slept in the same bunk-bed when I was pregnant with my younger daughter, Judit.

That was the time of the Heine-Medin epidemic. Gyözö Ferencz rang Petö from the László (Infectious Diseases) Hospital to tell him that the hospital was full of cases from the Heine-Medin epidemic and that those who were safely over the acute stage should be taken away to make space for new patients. He wanted Petö to take them in at his Institute and rehabilitate them there. After the 'nose-wiping' episode Peto' taught me regularly and even gave me special lessons. He sent me out to the László Hospital, to the pavilion where the iron lung patients were. There were six of them altogether.

A doctor led me into the room - dressed in protective clothing, naturally! My task was simply to observe: I was not to breathe a word or move a muscle, just be very attentive and, if I saw the initial signs of one of them starting to breathe unaided, to point them out. I agreed with Dr Ferencz that they would start transferring the patients to our Institute. First they had to put the paralysed patients, who were unable to breath, into an oxygen tent and then into the fresh air for a minute or two so that they could

\footnotetext{
${ }^{93}$ Interview with Ágnes Kenyeres

${ }^{94}$ Zoltán Zsebők: Prof. of radiology, Cultural Under-Secretary of State

${ }^{95}$ Károly and Magda Ákos, The enigmatic Dr Petö, The Conductor. Vol. VI. Nos 3 and 4 Is. 23-24.p.50.t.

${ }_{96}^{96}$ According to Anna Ratkó and the Personnel Department's file No 3360/P/38/1950 at the Ministry of Public Welfare

${ }^{97}$ Interview with Ilona Székely
} 
practice the necessary motor functions. They would contact us only when the patients were able to breath with their own lungs, without the help of a respirator, whilst asleep. That is how Heine-Medin patients were transferred to the Villányi út Institute. Pál László and Pál Hideg worked in our Institute after their recoveries. There were also other Heine-Medin patients but they were not respirator patients. There were two rooms at the Villányi út Institute for patients from the hospital, and we accepted some others, who were severely spastic, at the urging of Focher who was the Director of a home for destitute children. 


\section{THE INSTITUTE}

Petö kept very strict routine in the Institute. From early morning till late evening everybody lived according to an exact time-table. As an in-patient at the time Katalin Hidvégi looks back on this period which exerted a strong influence over the whole of her life: ${ }^{98}$

I went to the Petö Institute in 1954 as a patient, as far as I can remember at the recommendation of Professor Károly Walter of the Szeged Children's Clinic. I was then fourteen. At the time they treated not only motor-disordered children but were also experimenting with the effects of physical and dietary therapy on all kinds of disabled children and even epileptics. The Villányi út Institute was residential and applicants were accepted on a first-come basis. I don't know what the total number of people at the Institute was, I think about eighty. There were some out-patients aged from three to five and some elderly cerebralhaemorrhage patients too, all of them categorised by age and diagnosis.

The group of which I was a member was aged from three to fourteen. There were fourteen of us in a big dormitory. The furniture consisted of fourteen plank bunkbeds and fourteen blankets. In the evenings a blanket was spread on the bunkbed, a sheet was laid on top of it, followed by another sheet and finally a blanket. There was no pillow. The assistants took great pains to ensure that everyone slept in an ideal position with extended limbs and either on their backs or on their fronts. If some children turned on their side or drew up their legs then they carefully woke them up and straightened them out nicely. If some children couldn't straighten their legs then sandbags were used to keep them in an ideal position. At night two assistants looked after us, during the day at least eight people looked after us. Naturally there were also nurses, conductors and cleaners. The nurses were concerned with our bodily needs, that is they fed us, gave us drinks and bathed us. The conductors performed the exercises. Presumably they had some basic physiotherapy training. That is not something a fourteen-year-old child would know but at the time there was no formal conductor training in Hungary. They were taught how to direct and conduct the exercise. Probably they learnt a lot while doing the exercises with us.

Our daily routine was quite military. We were woken at six. Their aim was for all of us children to look after ourselves as far as we were able, that is to say that we children had to dress and wash ourselves, brush our teeth, put away our own bedding and possibly help the assistants put away the beds. There were in the Institute, you understand, no separate spaces for dormitories, dayrooms and physiotherapy, rather we slept, ate, worked and spent our entire day in the same room. There were also chairs and they brought in tables for mealtimes or rather, during the day, these were stacked against the walls like the bunkbeds to make room. The blankets were spread on the floor and we did our exercises on them. We had to finish dressing, washing and eating breakfast by eight o'clock each morning. Occasionally we didn't eat there but the tables were set up in the so-called Out-patient's Department and we had to go there, or rather they took those of us who couldn't walk since there were of course some such in our group.

Here they laid such total stress on the development of independence that even those whose hands were paralysed had to try and look after themselves. Either they would wedge a hairbrush between the planks of a bunkbed and then one could brush one's hair by moving one's head against it or struggle somehow to complete the action with our limited movement. The conductors were most strictly forbidden to help us in satisfying our physical needs. But in

\footnotetext{
${ }^{98}$ Interview with Dr Katalin Hidvégi
} 
the last ten minutes before eight they started to help and naturally nobody stayed hungry. But as far as it was possible we all had to complete our own task on our own, each of us had to serve ourselves out of the common dish or pour out of the water jug by our own efforts. If the child was hyperactive, then he might miss his glass, might even miss it twenty-five times. One day we ate with our right hands, the following day with the left, so that we could use our hands in the same way and we had to use our paralysed limb just as well on the given day. This was done with such strictness, that there was a sign put out on the table, with TODAY WE ARE EATING WITH OUR RIGHT HANDS written on it in big capital letters. The following day they changed the sign and then TODAY WE ARE EATING WITH OUR LEFT HANDS was written on it. This was supervised very seriously and if by any chance someone wanted to use his healthy arm without permission, he was punished by expulsion from the Institute. This happened to me once. One had to be ready by eight o'clock, dressed and finished with breakfast. From eight to noon there were prescribed floor exercises for fifty minutes. The nurse told us what we had to do and we had to say slowly, articulatedly and clearly:

'I am lifting up my right arm, one, two, three, four, five. I am holding it, one, two, three, four, five. I am lowering it down, one, two, three, four, five.'

You were not allowed just to just drop it back. As many times as it fell down, then so many times you had to lift it up again to the same height that it fell from, and then you started again from the beginning. Usually we repeated the exercises until everybody in the group could achieve the desired goal, which meant ten, fifteen, twenty times, one after another. These exercises were designed to make all the muscle groups work systematically.

There were ten-minute breaks between lessons in which you could go to the toilet or drink a glass of water. During the exercises it was strictly forbidden to go out to the lavatory, you had to hold it back. If you definitely couldn't hold it back, then you had to urinate in your clothes but you had to continue with the exercises until the break. So there were exercises until twelve, sometimes till only eleven, and then walking exercises followed. Somehow everybody got to the vertical position. Even if they couldn't stand unaided at all. There were chairs with high backs, and even if only with the help and support of three nurses we all got into a vertical position, and then the walking exercises followed in such a way, that the chairs were moved forward and we had somehow to carry our bodies after them. After the walking exercises we had lunch. That was special. Since they were trying to feed us in the richest possible way in calories, minerals and vitamins, only those who had worked exceptionally well during the week were treated to soup but even then only once a week, or maybe on Sundays as well. The meal started with a big dish of raw vegetables, cut-up carrots, lettuce and other kinds of green vegetables full of vitamins. We had to eat them first. Then came the main course, rich in protein. In order for us not to gain weight we did not get many sweets, only on outstanding occasions such as festivals, birthdays and namedays. A tin pot was brought in full of mixed fruit drops and Kati, one of the conductors, gave one to everyone. But we got a lot of ham, cheese and sour cream: for example at teatime, a glass of sour cream with quarter of a pound of ham, without any bread.

At lunchtime, after having eaten the vegetables everybody had to tip their heads back and the nurses poured down a tablespoon full of calcium, a few vitamin pills and a spoonful of codliver oil. The clever ones did not swallow it immediately, they tried hard to keep it in their mouths and then to go to the bathroom and spit it out there. Naturally being children we did not know that did no good to flush the toilets, the oil floated up again to the surface. The conductors checked the bathrooms and, if there was any oil floating on the water, they poured cod-liver oil down all our throats again. There was siesta after lunch, two hours' afternoon sleep. We were not allowed to talk or read... While I was there at the Institute education had 
not yet been introduced. At that time I was already a first-year student in a grammar school and I managed to continue my studies in such a way that I took the exams separately, at the end of March. From the beginning of April to the end of October I was in the Institute, and then I went back to school again. Later some teachers from a primary school near by went regularly to the Institute to give lessons that took place in the afternoons.

In the afternoons there was an hour of walking exercises, for example to improve our sense of balance, they would put a breadbasket on our heads, which was not allowed to fall down. If it did fall, the breadbasket was put back on our head again and we were reminded that they were not careful enough and should be more careful next time. This lasted until five. At six we had supper. As the calorie-rich tea had been at four, for supper we got very light vegetable purees, on Monday spinach, Tuesday sorrel, Wednesday mixed vegetables, and then again sorrel, spinach and mixed vegetables. During that time I had enough vegetables to last for the rest of my life. So in the evening we always had such a light supper. After supper we had free time, when the conductors read stories, arranged games for all of us and during this time we could write letters or read, and, as far as I remember, we had to go to bed at nine.

There was a flute course arranged for those who had arm disorders or could move their hands only with difficulty, and while I was there a well-known flautist from the Opera House gave us lessons twice a week.

Theoretically only those of us whose arms were paralysed could have flute lessons but unofficially a few other children who could move their fingers well also took part in the lessons, among them András Pernye ${ }^{99}$ who came to like Blockflöte there. I was also in this group and when we had visitors we had to perform. Those who could play really well were taken to the Opera House, which was how I got to go there for the first time in my life, to see Madame Butterfly. Five of us were taken then, and as teenagers we wanted to get beautifully dressed, to put our civil clothes on. But in the afternoon three head physicians appeared and got us dressed in our chequered uniforms, we put on our cork-soled shoes and were told that we should be proud of being Movement Therapy Institute patients and not be fussy about such superfluous matters. We were taken by taxi and in the interval the conductor was asked to come and see us and talked to us about the beauty of music and the magnificence of opera. I managed to get to the Opera three times and my love for music may have had its foundation there.

They all had to work according to the best of their abilities. Petö did not only expect this, he also checked on it. László Horváth recounts:

Gábor Palotás, who was an incomparable man, told me the following story. He worked for Petö for a long time. Once he somehow didn't place a child's foot in the correct One-twothree-four-I-step way and Petö shouted at him:

'Doctor Palotás, leaves the room. The lawn needs trimming!'

There were bricks out there, cement blocks, the asphalt didn't bond properly between the blocks, the grass grew up, the roots began to strengthen, and this made the pavement wobbly. The children couldn't walk straight on it. This was the grass that had to be pulled up:

'You go and weed the grass right now!'

Palotás was pulling grass in his white coat for a week. By chance a delegation came from the Ministry and they asked:

'Gábor, what are you doing?'

'I am pulling up grass. '

\footnotetext{
${ }^{99}$ András Pernye (1928-1980) music critic
} 
'And what possesses you to do that?'

'The boss told me to...'

There were lightning changes in Petö. For example, he noticed after lunch that there had been grenadines and almost all the food was left on the plates.

'Where is the cook? Take your papers, and good-bye, I don't want to see you here tomorrow'.

'Why? the cook asked.

'Look at this!, The children won't eat what you made! So you are not a good cook.'

But he didn't know who was going to cook the next day. He was that kind of man..

Auntie Ilus, who was the wife of a cashiered colonel, couldn't get hired anywhere else but he took her on. And it was she who told me how the employees started to cook after that, instead of the cook who had been fired in the blink of an eye. ${ }^{100}$

The same story is told by Palotás ${ }^{101}$ :

He was very perceptive. Once he sat on a chair on the corridor of the Institute He didn't speak, he just sat there. Mária Hári was hovering around him but he didn't speak at all. After a while he suddenly shouted:

'Gábor, come here! Fire the cook!'

I thought 'Why should I fire the cook when he is a good, professional man?' But I didn't answer, I didn't do a thing. In the evening in his apartment, sometime around midnight when the doctor was already tired, I asked:

'Why do we have to fire the cook?'

'Because he doesn't cook well.' answered Petö who never even tasted the food.

'Why do you think this, Doctor?'

'Because today a lot of left-over food was taken back into the kitchen.'

'But not because it was bad but because they gave so much.' I answered.

'Oh! Then don't fire him!'

Pető built his in-patients into a real little community. The Villányi út Institute was already in existence when Károly Ákos visited with his wife Magda: ${ }^{102}$

He showed us around. The Institute was full of children with Heine-Medin. Today one can hardly remember what the Heine-Medin epidemic was like. But then there were lots of children, twenty to twenty-five of them in a room, in a terrible condition. You have to imagine a child whose arms were just skin and bones... Incredible, but at the same time these children were cheerful, they behaved normally, just one could not walk, another could not lift up arm and so on. They did Peto's series of tasks which have later become well known. One child had his right arm paralysed, another had her left arm, the whole group was like that. Peto thought out a task and the children had to sing:

'I am lifting my right arm, I am putting it on my head and I am lowering it down'.

In this way the children knew what task to do, namely that they were to swing their arms with their shoulders and then those skeleton arm would swing up high and they only had to put their heads under their arms. That was it.

Honestly, I have to tell you that I thought it was a load of rubbish. But later both my wife and I were there when one of these paralysed children, a seven-or eight-year old boy, took his first step in his life. Then the conductor said to the group:

\footnotetext{
${ }^{100}$ Interview with Dr László Horváth

${ }^{101}$ Interview with Dr Gábor Palotás

${ }^{102}$ Interview with Dr Károly Ákos.
} 
'Let's count together with Joe!'

And while the group was counting, Joe's paralysed leg started moving and he put it forward. He was beet-red from excitement and the whole group was screaming like football fans at the victory of their team. And then Joe took a step.

The children were very happy. What made them so happy? This is how Miklós Tomcsik, the part-time anatomy teacher, saw it: ${ }^{103}$

With few exceptions, these were in a strange way very happy children. Well, they were not all deformed or not too deformed. But somehow they accepted that they were like that, maybe because all the others around them were the same. That seemed normal. They lived in a community where there were similar children. They sat on benches or in the playground, they couldn't stand up.... It was unpleasant when I arrived while they were having tea or supper. There was a room where, during the day the children played, acted and so on, and there were little tables with chairs set out, where they had tea or supper. I had to cross this room to get to the classroom. The children would pull at my trousers: 'Please, tell us a story!' They were taught there that if they could not hold the spoon as others held it then they should hold it as well as they are able to. They were really jolly and they played a lot. I also saw them acting a lot. They probably did other things as well but I always saw them acting out different situations. They pretended that those who didn't play with the conductor had to limp and were not allowed to walk properly. These were very solemn pretend tasks. The children had makebelieve situations with which they practised certain movements. That was very serious work. These children had trouble with even putting two building blocks on top of one another. They had to learn to put one block on top of the other even with poor hand co-ordination if that was their particular disability.

Károly Ákos's opinion: ${ }^{104}$

Then I asked Petö why it was good if a child could put his paralysed arm on his head. His answer was that the particular child would then be able to hold a comb with that hand and able to do something with his hair, which would give the child the feeling he is combing his hair. It was Kunsternek who first thought that a person could do certain movements even if paralysed because, when given a light object in the hand, the joint holds it. This is called tonicity. Since Petö gathered information from a remarkably wide range of sources, he used Wester's method too, but with the wonderful addition that the patients would not just stand but also say to themselves: 'I am standing straight'. 'I am putting my right leg forward' they said and then Petö taught them how to do it. One had to give the leg an impetus, then the leg would immediately take a step. The interesting thing was that the patient did it more easily and better each time. Petö told me that the muscles would recover. I was sceptical, as one could imagine, that motor-functions could start working again, since the motor nerve-cells attacked by the Heine-Medin viruses had been destroyed, but later the motor functions did recover nonetheless. He said that there are reserve nerve cells that can be mobilised in their stead, which in fact can be accepted. But how does the muscle return to functioning again? When I wrote my book on Conductive Education I racked my brain over this problem. Then, as I read the specialist literature on the theme, I realised that by then it was already known that the nerve cells in fact function as a gland.

\footnotetext{
${ }^{103}$ Interview with Dr Miklós Tomcsik.

${ }^{104}$ Interview with Dr Károly Ákos.
} 



\section{FRIENDS AND ENEMIES}

Petö's work was looked upon with hostility by almost the whole medical establishment. His method did not fit in with medical science, though the then popular theory of Pavlov and the introduction into Hungary of movement therapy, which was at that time regarded as 'Soviet', protected him like a shield and legitimated him politically. His method was in concordance with the results of Soviet neuro-physiological research. In the circumstances of the time it was difficult for conservative medical circles to inhibit any activity with which the Soviet 'superiority' could be proven. At the same time international traditional medicine rejected Petö's method as 'para-medical', not fitting into existing systems. Applying and teaching movement therapy seemed a completely new field to Hungarian doctors but there were still some who evinced interest. Dr Károly Pap, university lecturer and orthopaedic surgeon from Debrecen, wrote a letter to Pető, expressing interest in movement therapy as a new political trend: ${ }^{105}$

\section{Debrecen, 10.10.1951.}

\section{Dear Friend,}

I have heard about your interesting work, which is in line with the method of Soviet movement. I would be most gratified if you could send me a copy so that I can make a thorough study of the matter.

I would consider it an omission if I should not be able to become acquainted with the opinion of the country's outstanding expert on Soviet movement therapy.

Petö also used his method effectively with adults. He achieved quick results with his therapy for the different back, lower-back, leg and other complaints of leading politicians and prominent personalities of his time. Béla Biszku, the Minister of Home Affairs, and Gyula Ortutay, the Minister of Culture and Education, belonged to the circle of his patients. Petö's method was needed in other fields of medical science too, according to a letter written by Dr Győző Petrányi, university lecturer and professor at a children's pulmonology department, in which (1954) he explained that, because after lobectomy movement therapy was suggested, he would recommend training nurses. Dr Károly Gyergyai asked Petö to provide six conductors for the Heine-Medin after-care unit which was opened (1955) in the Bókay Children's Hospital. Pál Gegesi Kiss, one of the important personalities

in Hungarian medical society, Vice-Chancellor of the Medical University, was one of the few people who acknowledged Petö's effective and special education from a professional point of view (his noteworthy colleague, Lucy Liebermann had also used movement education with hearing and speech impaired children since the nineteen-thirties). He gave Petö the chance to give lectures at the university, which lent Petö medical recognition.

When after the Liberation I was appointed Professor and Director of the clinic, the consultation hours became more and more intensive. It was during these times that Petö came into contact with me as the Director He told me his concept and I agreed with it completely. The essence of his method lay in the effect of bodily exercise on mental functioning and vice

\footnotetext{
${ }^{105}$ In a glass display cabinet at the International Pető Institute
} 
versa, put into practice with young infants and children in order for their condition to improve. Petö never wrote this down but this is what he was doing as he described it to me. I answered:

'My dear colleague, I have five lectures every week, and I 'd like to give you one so you would start to teach the fifth-year students and all this could become an integral part of their body of knowledge in child care'.

This was sometime after 1946 but I cannot recall when exactly. I didn't consider Petö an immediate colleague like Liebermann who was receiving patients. In the clinic Petö only gave lectures to the medical students and he began to organise his own Institute. He taught the conductors how to work with the children through emotions and how through emotions you could reach them intellectually and develop their movement at the same time. Later on, these sessions were filmed. ${ }^{106}$

On one hand Petö was needed - for example, they couldn't do anything with the HeineMedin patients without him - but at the same time they did not want to acknowledge him from a medical point of view. It is true, however, that research into the brain had not yet reached the point where Petö's method could have won scientific approval. Leading anatomists acknowledged Petö's work only after his death, a good example of which is Academician János Szentágothai's ${ }^{107}$ inaugural speech $^{108}$ at the opening of the new Institute on Kútvölgyi street, on 16 April, 1985:

I was deeply impressed by what I experienced on my visits to the Institute, which experiences contradicted or rather seemed to be standing in surprising contradiction with what we had been taught in medical science in connection with neurology... I was almost astonished to see, that the wonderful... reorganisation and rehabilitation of functions happens by itself, that the nervous-system knows much more than we had assumed... But it was precisely these results that I saw in this Institute that assured me, yes, the method which Peto" worked out at the time' about which he was fanatical and spoke with great conviction, trying to develop it further in the face of much opposition, and which he finally carried into effect with great international success, well, despite of all the medical considerations, there is still much more potential hidden within it.

Even in such serious cases where one might as well say 'let us leave it to modern technology', trained conductors with their enormous commitment and educational efforts can achieve results which mean a definite easing in the lives of the motor-disordered. I think it would not be right to look in the direction of computerised robot nursing systems, and chairs and beds moving by themselves at the push of a button, when searching for a way forward.

The way in which we should be developing lies in the fact that we can get wonderful results through systematic work. In many cases these results cannot be scientifically surveyed and some parts cannot be fully understood but we always have to think that, if there are connections in the central nervous system at all, then miraculously the function will be regained to a certain extent. This can only be achieved, however, with enormous work and outstanding enthusiasm from patient and conductor alike, with steady practice and constantly maintaining a standard, and with continuous raising of that standard.

\footnotetext{
${ }^{106}$ Interview with professor Pál Gegesi Kiss.

107 János Szentágothai: (1912-1995) Medical researcher, anatomist, neuro-anatomist, corresponding member of the Hungarian Academy of Science, recipient of the Kossuth Prize, researcher into the micro-structure of the nervoussystem. Member of the Anatomical Science Lenhossék dynasty, researching the tissues in the nervous system.

${ }^{108}$ From Mária Hári: The history of Conductive Education. pp 229-230. Budapest, 1997. MPANNI
} 
...I am absolutely sure that this therapy is not charity but a deed done in the best interest of society. First of all, because a person of limited motor function or a rehabilitated motordisordered person is actually a better worker than a healthy one who takes the gift of life for granted. But those who get to a certain level of performance through hard work, will always value this so highly that they will be more motivated members of our working society. This is a victorious initiative for our educational and pedagogical system, which has already achieved results, but the true flowering and unfolding of those results will only now become apparent.

Pető spent his whole day in his Institute, from early morning till late evening. He had the habit over the years to go to cafés and he invited his acquaintances, friends or colleagues, either there or to his flat so that he could have conversations with them. In the evenings he often gave dinners. The meetings in his flat were good opportunities to talk over different themes in a relaxed atmosphere. László Horváth tells a story:

I was invited to supper at Petö's house a couple of times, and once we were invited for seven pm. We rang the doorbell. He had an old housekeeper, she showed us into the hall to wait, the doctor would come in a short while. We waited some fifteen minutes and by then we were already thinking we had come to the wrong place. The woman opened the door and I saw that Doctor Petö was sitting in his room reading a newspaper. Strange. I started to speak louder and he came out:

'Doctor Horváth! Let me tell you that if you see couples walking around in England you will see that they ring the doorbell at exactly seven when Big Ben tolls. You are fifteen minutes late.'

Well. I lit a cigarette.

'Where are you putting the ashes? Here's an ashtray!'

'Well,' I said, 'we are not in England.'

'All right, well, sit down.'.' 109

Ágnes Kenyeres tells another:

From 1959 on I was invited to his house for supper once a month. He had a housekeeper, the table was always neatly laid. He usually ate lobster or snail, at that time there wasn't much to eat at all but on a plate there were three slices of meat with gravy and I ate one of them:

'Thank you, doctor, I couldn't eat any more.'

Then he told me to eat them all and would not take no for an answer. When he left the room for something. I put the leftovers into my handbag, which he didn't notice. Afterwards we ate that meat for three days. I would always take some grease-proof paper with me and take the food home. He never noticed.

More than once I wanted to give him something in return but he wouldn't let me. Then once I was invited on Christmas afternoon. There was nothing there, I just sat down and we talked. I had brought a bottle of wine and asked him to accept it. He said:

'Before you came, Olga Szentpál'10 was here. She drew me a Christmas tree with birds around it. That was a gift. This is not a gift, take it away'. 111

\footnotetext{
${ }^{109}$ Interview with Dr László Horváth

${ }^{110}$ Olga Szentpál (1895-1968) Pianist, dance teacher. She studied movement art at the Delcrose College in Hellerui. In 1944 she founded a school of movement art, which Ortutay's wife also attended.

${ }^{111}$ Interview with Ágnes Kenyeres
} 
And Júlia Dévai another:

The whole operation was directed by Petö sitting at the table in the Café Elysée. It was his general headquarters where he received his friends, admirers, and students, sometimes as their host, at other times as their guest.

He liked good food, good cigars and spirited talks about the latest news of the literary world, about the arts and politics or scientific events. He made his plans there with detailed notes about everything, carefully dispatching, delegating, and controlling every single task. It never happened that he assigned something and forgot about it. No. You could be sure that once he told you to do something he would get back to you and ask about the outcome. We never knew why and never questioned either each other or ourselves why we were so eager to help, to accomplish, to contribute, with no salary, no money whatsoever, no great career possibilities either. It must have been just his belief, his total commitment that infected us. During this whole period he never ceased to see his regular patients and if he had no time to visit them in their homes there were always some of us who would proudly volunteer. ${ }^{112}$

Béla Biszku tells:

He selected the patients too and had a bitter fight with Bárczi about motor-disordered children. Peto" stated that they had perfectly sound minds and were just hyperactive and had communication problems. He did not allow the use of special education for such children since he said that if it were to be used then it would damage their independence. I saw the children whom he treated and I saw their progress as well. Petö did not accept mentally handicapped children in his Institute since, if he could not communicate with the children, he could not achieve results. ${ }^{113}$

In August 1954 Pető had a coronary thrombosis. He was ill for a long time but still wanted to know about everything happening in the Institute. His colleagues, Ilona Székely and Mária Hári, directed the Institute under his guidance. Bárczi wanted to separate the Institute from the College of Special Education, probably partly because of the uncertainty of Petö's recovery and partly because of the conflicts with the Ministry of Health. Petö's opponents, centred around Simonovits, the Deputy Minister, did not even accept Pető's results: 'The Institute is a dark place, full of failures and quackery.' ${ }^{114}$ At the same time the newly established Orthopaedic Clinic would have been grateful to expand and get a new institute and Bárczi wanted to attach Petö's Institute to the Orthopaedic Clinic:

Once after Petö's stroke, Gusztáv Bárczi made a grave mistake: he wanted to transfer Petö's department to the orthopaedic clinic. This was because Bárczi liked to work with the mentally disabled, with the deaf and the blind, not with the somatically retarded ones, not with somatopaedia. ${ }^{115}$

Petö had a serious quarrel with Bárczi and left the College of Special Education. The Director of the College portrayed Petö in the following way:

A selfless working style and incredible endurance is characteristic of him but at the same time he is brusque and very difficult to get on with. He cannot easily accept criticism but he himself is a severe critic; he often hits the nail on the head but is frequently aggressive.

\footnotetext{
${ }^{112}$ Recollections of Júlia Dévai:

${ }^{113}$ Interview with Béla Biszku

${ }^{114}$ From Mária Hári: The history of Conductive Education. p 98. Budapest, 1997. MPANNI

${ }^{115}$ Interview with Dr László Horváth
} 
Béla Biszku continues:

Oh God save him from the Ministry of Health! He was particularly angry with the Deputy Minister at the time, a certain Simonovits, who was dead set against the method. I don't know much about the professional dispute against him, I only know that Petö's work got results. That was why they made a film of each patient who was accepted into the Institute so that they could prove that they had improved when they went home after the treatment. Earlier, before this method existed, such people would have died like animals in cages. I'm not saying that such people become champion runners but they can at least get by, they look after themselves, they learn professions and that's a marvellous thing! ${ }^{116}$

Many people treated Pető like an enemy and many times information was laid against him or inquiries were instituted for him to fail. ${ }^{117}$ As a consequence, in 1955 he received a written warning from the Ministry of Health, according to Section 112 Paragraph 3 of the then current Code of Labour because, as it said:

András Petö is rough, impatient, uses family clans (Székely family), where Ili, Mrs Székely was the chief-conductor and her husband worked for the Institute as a general factotum, and he does not keep records of paid holidays properly. ${ }^{118}$

The report contained no further official condemnation of Petö.

In the Institute the work comprised two streams, educating the patients and training the conductors, the people who were directly in contact with the patients in their education. Education and training went on at the same time, since the education was the training. A great body of manuscripts was collected, concerning tasks that had been written down. But the scientific background and the conditions for training had to be established. Petô used all his strength and connections to belong to the Ministry of Culture and Education instead of to the Ministry of Health, as he was not respected there. That is why the name of the method was changed from movement therapy to become conductive pedagogy.

Simonovits caused the treatment of Heine-Medin patients to be discontinued. According to Károly Ákos:

President Roosevelt also had Heine-Medin disease and they couldn't do anything with him. Petö would have cured him, of course. Because of Simonovits a lot of people could not walk since he forbade Petö to treat Heine-Medin patients. He demanded that Petö show him his original degree because Simonovits didn't believe he had one. It was as if the recovery of the patients depended on whether Petö had a degree or not. I know a lot of medical doctors who were not able to cure Heine-Medin patients.

After the exercises we talked, and Petö told me - although in fact I had already heard it from others as well — that he had to fight very hard to keep his Institute independent of the Ministry of Health. I couldn't understand why this should be important to him and he explained that it was because his treatment was basically a matter of educating the patients. I think that

\footnotetext{
${ }^{116}$ Interview with Béla Biszku

${ }^{117}$ Reporting someone to the authorities had long tradition in Hungary. During the war, under German occupation, the German administration was surprised to find that most reports were made by Hungarians, as this was unprecedented.

${ }^{118}$ Personnel Department at the Ministry of Health 1451/25/1955.
} 
that is correct but that it is only part of it. Petö strove to remain independent of the Ministry of Health because they opposed his Institute on professional grounds. ${ }^{119}$

Tamás Vekerdy saw this problem in the following way:

Luckily Petö had successfully treated members of some families in the higher ranks of the party and they provided some protection. As a result of anonymous denunciations a delegation from Party Headquarters went to see for themselves and they were spell-bound by the sight of the children moving their 'officially paralysed' limbs whilst counting or singing - they also used official Socialist songs for the purpose, which were not supposed to be moving from the medical point of view! This was a deliberate little trick on Petö's part! He amused himself with such little tricks and sneered at their predictable effects on the officials. And then, with the help and support of friends and colleagues, among them Sándor Török, ${ }^{120}$ came the big twist: he and the Institute did not heal the children but rather they educated and developed them. Hence the Institute was not a medical institution, and did not come under the jurisdiction of the Ministry of Health. The Institute became an educational institute, moreover an institute of special education, in fact it ought to be called the Teacher Training College for Special Education. And that is what it soon came to be. And so Petö was not the Medical Director any longer but the Headmaster of an institute: the Teacher Training College for Special Education. And of course his staff no longer consisted of nurses and physiotherapists but educators, or conductors as he called them. The conductors were the guiding companions of the patientspardon me, pupils. That is how the Movement Therapy Institute became the Educational and Training Institute for the Disabled, since obviously Peto" would not entrust the training of his colleagues to anyone else but at the same time he achieved recognition of his students' qualifications as a kind of special education qualification, under the auspices of the Ministry of Education. Since pedagogy is not a science, it endured and bore what medical science could not bear, that despite the fact the nerve-fibres were inoperative the stimulus still travelled down them. Movement followed the brain's command whilst the pupil was counting, in order to give room to the ministering forces in the organism, which cannot be explicitly named. ${ }^{121}$

In 1963 it was finally recognised in law that the Institute belonged to the Ministry of Culture:

An Educational and Training Institute for motor-disabled people should be established under the direct control and guidance of the Minister of Culture and Education, in order to assure education and upbringing with special (conductive) methods for motor-disordered people hindered in their movements as a result of damage to the central nervous system, and to provide training for the educators who would accomplish the work. ${ }^{122}$

The law defined the Institute's tasks:

- $\quad$ to train conductors to educate motor-disordered people;

- to restore motor-disordered persons by using conductive pedagogy,

- to bring up children under school age [in Hungary, six years], providing them kindergarten activities;

\footnotetext{
${ }^{119}$ Interview with Béla Biszku

${ }^{120}$ Sándor Török (1904-1985) writer, playwright. Editor of the periodical Család és Iskola (Family and School)

${ }^{121}$ Tamás Vekerdy: Álmok és lidércek. Budapest. 1992. T-Twin

${ }^{122}$ Hungarian Gazette No 89. 21st December 1963: The Hungarian Workers' and Peasants' Government Decree, 21.12.1963/36.
} 
- to accommodate school-age children and adults, and to teach them and provide vocational training;

- to undertake scientific research connected to the application of conductive pedagogy.

The Institute was declared a college but the hand-over between the two ministries did not go smoothly. An agreement was written between Dr Frigyes Doleschall, Minister of Health, and Pál Ilku, Minister of Culture and Education. The Ministry of Health still provided ambulances for transportation, the laundry services and staff with medical job descriptions, and arranging the number of lessons could be agreed only with the assent of the Ministry of Health. Documentation and personnel data were handed over and the employees were transferred to the Ministry of Culture and Education.

The Hungarian Workers' and Peasants' Government passed a separate resolution that the Institute would disseminate conductive pedagogy over the whole country, it would establish a network of institutes in the countryside and keep national records about motordisordered patients. The Institute had to provide treatment, education and upbringing for in-patients and outpatients and the conductors had to receive a teachers' qualification. The education had to be free and residential placement had to be free for two years. ${ }^{123}$

The ever-expanding Institute looked for a new building and a place was set apart for it on Kútvölgyi út, next to the Party Hospital. Petö still participated in the process of planning and design and in the early battles but in 1967, after a heated debate lasting six hours, he became unwell and died.

Mrs Székely witnessed this:

He was wearing a worn, grey coat when we took him in to the Institute on that last day: he was already past recovery but he wanted to go to the Institute. I went to his flat to give a report and he said:

'Ring the garage caretaker to send me a car'.

The garage caretaker probably dropped the receiver in amazement: 'Comrade Peto" is going out?'

'Yes, 'I said, 'he is going in to the Institute!'

When we got in, Peto''s lips were already grey. He asked me to ring half the city, everybody who counted in the health authorities. He even asked me to ring László Pesta ${ }^{124}$ who at that time worked in the Parliament House in a very high position, all rehabilitation matters including the social rehabilitation of recovered patients were under his auspices. Pesta promised that he was going to intercede in Parliament about reserving certain jobs for adults who recovered at the Institute and were able to work. There is a list of the people who got work there and some of them still work there today.

So, when we got to the Institute he summoned together people in high positions. An exchange of views took place between them about how legally to protect those who recovered from their conditions so that they would still be able to work. This meeting went on from nine in the morning till the afternoon. In the meantime he asked me to bring coffee. I didn't dare tell him in front of the guests that we didn't have cups, and for people of such high standing we couldn't offer the mugs which the children in the Institute drank from. I

\footnotetext{
${ }^{123}$ Law Reports 30th December 1963. Volume 13. Number 15. 2031/30.12.1963.

${ }^{124}$ László Pesta (1902-1969) doctor, health politician, President of Hungarian Red Cross, President of National Social and Public Health
} 
started thinking how to solve the problem. I ran hastily to the Finance Director and told him that we didn't have any coffee cups, just plastic mugs with two handles. We ourselves used those, just like the children but we couldn't serve coffee in them. Finally I poured coffee into big water glasses which had been bought for the children, I put them on a big tray and, balancing it, I took it in and put it on the table. Suddenly Petö shouted at the receptionist, 'Ilike, Marika!' The receptionist had to work out from this that he wanted to see us but he hadn't said so in so many words, just: 'Ilike, Marika!'. I ran to fetch Marika and then we went in. I stopped in the doorway and looked at him: he looked very unwell:

'Well, I've sorted that out,' he said, 'Don't forget this. Mr Pesta is going to intercede. He's an honest man but may not be able to keep his promise.'

Everything and everybody had to be checked, even himself, so that nothing would be forgotten. He had reason to check everything but he was even stricter with himself. There were still two glasses of coffee on the tray. Petö knew that I adored coffee and he also knew that I smoked. Nobody was allowed to smoke except me. The two of us sat there and drank our coffees. Suddenly he looked at me, stood up from his chair and came over to me, his skin had a strange colour, and he said: 'Oh, Ili, I'm going to die.' He sank into the armchair, falling forward. I put his medicine under his tongue but in vain. It was too late. 
As many different Petős live on in memory as there are people who remember him. This is how Ilona Székely saw him: ${ }^{125}$

He was a magnificent and excellent man. Only those got to know him were able to understand his very complex personality. For Petö everybody was the same, he didn't differentiate between people whether they had a coruscating personality or talent or not. One had to love him very much to understand him. A lot of people didn't know this and even more did not understand him, therefore they didn't like him. He did have many enemies but there were still were many who admired him, those who had understood him.

He helped a lot of people, not just with his knowledge, he also financially supported those in need. A book had to be kept about how much money he should give to people. He didn't even know how much his salary was. He was paid from different places and he just stuffed it into his pocket. I know of at least two occasions when we left his salary behind in taxis. In taxis he was always talking about tasks, or he would be busy with something else and put the money next to him or he'd pull a handkerchief out of his pocket and pull his money out with it. But cases like this did not trouble him.

He gave people back their faith in the most impossible and hopeless situations. The wife of one of his best-liked patients, who was almost completely paralysed feared that her husband was going deaf as well and, terrified that he husband would be unable to live in such a condition, said to Pető:

'Doctor, if Imre goes deaf, I will poison him.'

After a short pause Petö said: 'I once had a patient in Vienna who had lost all other faculties except that he could move his eyes. He had a typewriter and his wife typed whatever key he looked at. He published a book that way. And now get out of here!' 126

\section{Béla Biszku:}

When he started to treat me I went to the Institute every morning at eight, even on Saturday and Sunday. He was an incredibly precise and painstaking man and was always sitting at his desk when I arrived. He was very strict but also very warm-hearted. His love for children and what he achieved for them were fantastic and I think he was very contented with his situation. Only very few people stayed with him or, to put it another way, he only allowed very few people to stay with him since he had very high standards and selected people very carefully... I can still remember exactly what he would say to me if I complained:

'What do you expect, do you expect only the good things in life? You are a happy man. You have a family. You have to be prepared not just for the good things in life but for the tough times as well. One has to know that there is struggle and suffering in life too...'

Another important point was that Petö did not let the children's relatives pay honoraria. He did not want to strip the parents financially, to take from them everything that they had....

Most of all I am very grateful to him for what he did for me and for the chance to have got to know him because although he was outwardly a very dour man he was actually very warmhearted when he unbent. He had four separate fatal diseases, an incarcerated hydrocele, terrible trouble with his stomach and he lived on a very strict diet. I often observed what he ate and I tell you it would have killed me! First of all everything was totally unsalted and he ate

\footnotetext{
${ }^{125}$ Interview with Ilona Székely

${ }^{126}$ Interview with Ágnes Kenyeres
} 
only vegetables and potatoes, no meat at all or only very rarely. The two Cerberuses who guarded this strict diet were Mária Hári and Mrs Székely. ${ }^{127}$

And Katalin Hidvégi:

Among the doctors I can definitely remember Doctor Petö who was already an elderly man, short and squat. As a child I considered him a very strict man who was determined to improve my movement and I was convinced that he could help. He did not tolerate any slackness, untidiness or misbehaviour, or failing to complete the exercises. Children who did not behave properly they punished, even to the extent of not being allowed to meet their visitors during the monthly visiting time, even if the visitors had travelled up from the country. This happened to me once. The porter gave a little lecture to my parents to the effect that rules are rules and they were not allowed to see me. These visits, which were only once a month, could easily be forfeited. He was a practically incorruptible man.... Later I became a doctor myself and I now understand that, although my paralysed muscles were not improved, I was taught to make much better use of my usable muscles and they were much strengthened. But above all else I was taught one thing of inestimable value: 'I am what every man is, grandeur' as the great Hungarian poet Ady wrote. I was taught there that my intrinsic value as a human being is not decreased with my decreased mobility and that, if they will it strongly enough a disabled people can live in the world. It is probably thanks to the time I spent in the Institute that I later had the willpower to finish Medical University, become qualified and start a family... I went to the Institute during that lucky period of life in which one's personality becomes formed, between the ages of fourteen and eighteen. They taught us to be both consistent and very particular. By very particular I mean that, whatever we did, we did it as nearly perfectly as possible. So I cannot do any physical exercise haphazardly but I have to do it as perfectly as I possibly can, no matter how many times I have to practise it. I learnt there that no matter how tired or fed up one is, one has to go on... The Institute was a place of great aspirations and we were taught to have high aspirations as well. We were taken to the opera and theatre and famous actors came to visit us. I consider this to be very important. Disabled children should be taught to love the arts from their earliest childhood because that compensates for their lost abilities. My parents had me learn to play the piano and when I was a teenager I was invited to all the parties to play the piano. At the time there were no tape-recorders and so I became the most important person among the children. This did wonders for my self-esteem, I did not become isolated and I had normal social relationships. I think that was a fantastic thing. And I played away my sorrows on the piano with Chopin's ballads. I still go to concerts even now as this is an important way for me to preserve my poise. ${ }^{128}$

László Horváth adds:

He smoked a cigar, he was always smoking cigars, and he was a Churchill-like figure. He took care not to leave any dirt behind. He smoked even when lecturing and somehow on 7 November we had to commemorate the Great Soviet Socialist Revolution. He gave a lecture and spoke of nothing else but movement therapy. At the end he said:

'Please know that the Great Soviet Socialist Revolution and movement therapy are one and the same thing.'

He took the full ashtray, put it in his pocket and left the room. ${ }^{129}$

\footnotetext{
${ }^{127}$ Interview with Béla Biszku

${ }^{128}$ Interview with Dr Katalin Hidvégi

${ }^{129}$ Interview with Dr László Horváth
} 
Miklós Kun remembers:

At that time I was working in Lipót Szondi's ${ }^{130}$ laboratory with Ferenc Mérei ${ }^{131}$ and Flóra Kozmuca (that is Mrs Illyés) and on top of that I had a private practice in my flat. And so I met Petö who was quite repulsive-looking, fat and pyknic. We were talking of different things when he asked me:

'What are you reading at the moment?'

I said the latest Thomas Mann book, to which he replied: 'You are reading such obsolete books?'

This man is crazy, I thought. 'What should I read then?'

'Kafka.'

'Who is that?' I asked.

'Read either Schloss or Der Prozess,' he answered.

He is mad, I thought but I browsed through the second-hand bookshops on Museum street and in one of them I found Der Prozess (The Trial). I read it and afterwards I went immediately out to Laci Gönczi 's. He lived in Hüvösvölgy and Petö was staying at his house. I went up to Petö and apologised. 'I apologise to you,' I said, because I thought you were talking nonsense but I now realise you were right. He was right, because The Trial is about prosecution which was the essence and motif of that period. ${ }^{132}$

According to Károly Ákos ${ }^{133}$ :

Petö was a mysterious man for us in addition to being a very good doctor. He was an unconventional doctor, his practice was full of tricks. Petö had enormous knowledge. In literature, for example, he was always up to date. He took a host of magazines that nobody else had in Hungary. He read and knew them all. It was very interesting that when penicillin allergy first became known, I became aware of it through him. He knew all the news and paid attention to it.

His assistant at the University, Gábor Palotás, speaks of him as follows:

I was his assistant between 1952 and 1954 on Villányi street. All his colleagues, the conductors and the whole team were committed to him. He was a peculiar man. An unique phenomenon. In his apartment on Stollár street we would talk about literature day and night. If someone new came into our circle, Petö's culture and education always astonished him. His head was full of poems and literature. The topic of why his chosen area happened to be movement therapy came up numerous times. His answer was always that life has chosen this for him; if he hadn't chosen this, he might have been allotted something much worse. This is why he never went abroad. We tried to persuade him: if only one person was allowed to leave the country and no one else, it should be Petö. Why wouldn't he go and travel? He answered: 'Recently I was in Gödöllo' and people had to tell me to leave immediately, because I was going to miss the last train. I wouldn't come back at all, even from Prague.

\footnotetext{
${ }^{130}$ Lipót Szondi (1893-1986) neurologist, psychiatrist and leader of the Biological and Pathological Institute of the College of Special Education. He left Hungary in 1943 because of the prosecution of the Jews. He went to Switzerland and to America. He founded a new school of depth psychology called 'faith analysis'. His tests of instinct diagnosis are used in psychiatry.

${ }_{132}^{131}$ Ferenc Mérei (1909-1986) child psychiatrist.

${ }^{132}$ Interview with Dr Miklós Kun.

${ }^{133}$ Interview with Dr Károly Ákos
} 
There was a compulsive desire in him to help. On pay days he mailed a ton of cheques to various people to help them. But money itself did not interest him. Especially not in return for treatment. ${ }^{134}$

Dr Júlia Dévai's recollections:

I met András Petö in November 1946. I was taken to his home on Stollár Béla utca by János Werkner with whom I used to attend the same class at the university. He was a former polio patient and a devoted admirer of Petö.

The home belonged to the Bródy family. Erzsi Bródy shared not only their home and food with Petö, but she also helped with his first treatments. A few years later she was accused by the Communists with an unbelievable and unrealistic spy story and she was imprisoned. After her release she left the country with her husband for Israel, where she died at a great age.

On that grey November day Petö was sitting behind his desk, leaning back on his chair. His eyes were only partly open but while talking to somebody he seemed to be aware of everything that was going on. He did not even look at us, only indicated the door to the next room with his head. I was eager to leave a place where nobody paid any attention to me and happily entered the next room. There were three people inside doing different things. One of them was lying on the floor and trying to reach the end of the carpet with his extended legs and feet. The other was sitting on a chair, attempting to lift a seemingly paralysed arm with the good one, and the third person was leaning on a chair, while bending and extending a knee along the leg of the chair. There was a slight murmur in the room because everybody was counting slowly according to the rhythm of their movements forced... The murmur, the quiet effort and the unbelievable concentration of these people created such a great tension the room, that there was no space left for questions. I was simply drawn into their world and before long I realised that I was unconsciously counting and sitting on one of the chairs to help stabilise it. I wanted them to succeed, I wanted that knee to bend and that arm to raise, with such a fervour that I hardly realised that Petö was standing in the middle of the room. He walked to every one of them, showed a better grip, turned something here, pushed a little bit there. The guy using the new trick Peto just showed him was finally lifting his arm and was all smiles, without interrupting our counting.

Petö had a sturdy body, massive, not too tall, with broad shoulders and a round, shining bald head. Especially while sitting, he gave the peculiar impression of a statue of Buddha. When he saw me sitting on the chair, enthusiastically counting, he smiled once more and with a royal gesture gave me permission to come again. The next day I was told by Werkner that this was the greatest possible praise anybody could ever get from Petö. From then on I was a frequent visitor to his apartment.

At the beginning Petö almost never talked to me... he kept working, but never accepted money for his work. He was living mostly on money offered him by his friends who took it as a personal honour, just like the Brody family felt privileged to offer their home to Petö. In his later years he still maintained a special relationship with finances. He kept his personal needs to a minimum. When at last he had a salary as the director of his institution and as a college professor, his whole income was divided among his friends and/or their families in need. It became the task of Marika Hári, later the Director of the Institute, to take care of distributing money.

\footnotetext{
${ }^{134}$ Interview with Dr Gábor Palotás
} 
At that time only half of his patients suffered motor problems, the other half or even more had internal or dermatological diseases. His methods were somewhat unusual in Hungary and could not be easily adapted to any traditional hospital setting. He was convinced that the essence of 'movement therapy', which was the original name of conductive pedagogy, was a learning process, thus it seemed logical to get this new discipline accepted through the Ministry of Education, especially as he had a few friends there who could pull some strings. In spite of this, the process was long and tiring, and full of unnecessary bureaucratic procedures which he did not intend to spend his time on...

For example, he did not like people with too much independent opinion but he did not appreciate dullness either. He wanted to be well informed about everything that was going on in his absence, so needed absolutely devoted, patial 'ears' around. He never cared whether we had time or not, whether we could skip classes at the university or how our families related to our spending so much time at the Institute (at that time I had a two-year-old daughter and a baby at home!). It is not that he was not interested in our lives, oh no, he wanted to know everything about us. It is just that he had this strange sense of time: you had to spend twenty hours with the kids, four hours with reading and administration but afterwards you were free to do whatever you wanted with the remaining hours.

If his instructions were not followed accurately, if some 'improvisation' as he put it happened, he became extremely upset. He flushed, shouted, shook his fist, pushed the sinner out of the door. But as quickly as he lost his temper, he soon forgot about it. He smiled, gave a kiss on the forehead, offered a book or a nice poem. Other than this smile, which was his only form of rare praise, you had to offer lots of hard work, with excellent results, no matter whether you were a child or one of us. Because of his great charisma, the magnetism of his personality, we not only worked hard but also enjoyed it.

Besides creating his original method and using all the available therapeutic possibilities for this, Peto was a polyhistor, a person of many talents. He was interested in philosophy and in contemporary maths and physics, and had a vast knowledge of literature. More than that, he was an excellent poet and an author of dramas portraying a Durrenmatt-type world. If he cared enough, he probably would have become a well known author but only his closest friends knew about and appreciated this side of his talent. In his wide circle of friends there were mainly writers, poets, and artists. His best friend from his early youth was Jakab Levi Moreno, the father of psychodrama. Zerka Moreno, the widow of Levi Moreno remembers Peto as a gallant, friendly, good humoured guy, who had abundant lady friends and was extremely well read. He loved his family very much, especially his mother. He never married.

Despite the fact that I belonged to his immediate co-workers only until 1952, we maintained a very close, regular, weekly relationship until his death in 1967. The time I could spend with him definitely determined my whole career, my medical thinking, and moral behaviour. Till today, thirty years later, his death is still a great loss to me. ${ }^{135}$

The poet István Vas ${ }^{136}$ writes about his meeting with Pető: ${ }^{137}$ :

$E_{t i}{ }^{138}$ is talking about the worsening of her condition to Déry ${ }^{139}$ and Andor Németh ${ }^{140}$, who say in unison:

\footnotetext{
${ }^{135}$ Recollections of Júlia Dévai

${ }^{136}$ István Vas (1910-1993) Went to schools in Vienna, poet and translator, recipient of the Kossuth prize, Outstanding personality of the third generation of Nyugat, student of Babits. His writings were published in Kassák's newspaper.

${ }^{137}$ Why does the bearded vulture scream? 1981. Bp. Szépirodalmi Publishers

${ }^{138}$ Etel Nagy, his first wife, was an excellent dancer (in Olga Szentpál's and Alice Jászi's circle of friends.)
} 
'Petö! Yes, he alone can help here.'

'Who is that' asked István Vas, 'a doctor'?

'He is more than that,' they answered, all speaking at once.

Andor Németh spoke with that characteristic irony of his which he used only rarely, when he wanted to hide his enchantment, but Déry spoke with open enthusiasm, with shattering seriousness:

'Magician, prophet, miracle-worker.'

They spoke of Petö as of a Cagliostro or a Svengali or as the Russian princesses must have spoken of Rasputin. They assured István Vas after his incredulous questions:

'Yes, of course, Petö is a doctor, he has just come from Vienna where he had a large circle of patients but had to flee from Hitler. As it is now, he could not quite settle in Budapest yet but he is already very busy and must organise his time carefully. However, they will try to get him to make time to examine Eti, and, if we manage to do that, then we can trust him, because he is the kind of doctor who heals through the soul...'

Pető came to Vas's house in Tibor Déry's company. He was noticeably ugly. Later, Vas heard Pető's younger fans speak of him as 'Buddha-Pető'. Vas writes how nobody could help Eti at the end, they didn’t diagnose her brain-tumour either. István Vas knew that

'...behind Petö's lightly pronounced statement that there is nothing wrong and the childish treatment hid the same diagnosis as Doctor K. gave them with merciless, life-shattering, willpower-destroying openness.'

Tamás Vekerdy:

Petö's personality attracted and fascinated me. He had a slight resemblance to Churchilland not only because of the cigar! His knowledge of Hungarian, German and Austrian literature was remarkable and he produced a flood of anecdotes and stories. His life was full of adventures. He read incessantly in many languages. He wrote plays in German, under a German pseudonym. He also wrote short stories. These were piled up in one of the cupboards - no-one was allowed to read them. He lived alone and his long-suffering housekeeper used begrudgingly to serve his guests according to his often capricious commands. Only a few of his followers ever managed to get close to him. He could be fascinating or quite blood-curdling. He would make penetrating pronouncements about others immediately upon meeting them. ${ }^{141}$

Péter Popper:

I don't think the Bródys lived there by then, the flat was almost completely empty, but Petö still lived in the servant's quarters which had a separate entry from the staircase. So one could go into his room not through the main entrance of the flat but from the stairwell too. It was a summer's day, it was hot, but still they had the heating on, which surprised me. Petö was susceptible to cold and sometimes asked for a fire.

To get back to the story, Petö was sitting behind his desk and dining. There were masses of books everywhere in the room and piles of magazines on the floor. There was also a delicate

\footnotetext{
139 Tibor Déry (1894-1977) novelist and playwright, poet, recipient of the Kossuth Prize. Studied in Switzerland. In 1919 during the time of the Hungarian Soviet Republic he became a member of the Writers' Directory. In 1920 he emigrated to Vienna, then lived in Paris and Perugia. In 1926 he returned home and became editor of Kassák's periodical, The Document.

${ }^{140}$ Andor Németh (1893-1954) writer, essayist, belletrist.

${ }^{141}$ Tamás Vekerdy: Álmok és lidércek. Budapest. 1992. T-Twin
} 
coffee table with crockery and cutlery laid for two and I was seated there. I'll tell you how it was. A strange woman sat down next to me. Mária Hári, who later won a national award. There was a housekeeper called Mariska, she showed me in. I greeted Doctor Petö and introduced myself. I don't know how he reacted because I was so overwhelmed by his appearance, he looked like Buddha. I don't know what that means to you but he was fat, bald, and his face was Buddha-like. Between his legs there was a hydrocele the size of a watermelon and because of this his gait was very strange. He had one row of teeth, of which he was very proud. Where he had teeth on the top, he didn't have any on the bottom and where he did have teeth on the bottom he didn't have any on the top: when he shut his mouth you could see only one row. He guffawed about this. Everybody called him the chief physician. Like Luther was called 'the doctor' so Petö was called 'the chief physician'.

We started dinner. Mária Hári and myself sat at the coffee table and the 'chief physician' at his desk opposite us. Mariska brought the food in. There was a big dinner for the time, soup and then fish with some garnish. I was immediately shocked by the unique way in which Petö ate fish. He cut big pieces with a knife put them in his mouth and then spat the bones out, like phü, phü, phü. It fascinated me and I was occupied with watching him eating the fish. But he didn't say a word. We didn't speak either. There was silence. This wasn't unusual with him. Sometimes he talked an awful lot, till late at night or till the first blush of dawn, and other times he didn't say a single word. It was evening. We were eating. Then pasta was served and after supper there was jam for dessert in water glasses for each of us. The chief physician liked it very much. We ate that as well. As I later discovered it is healthy, it's good for the heart. Afterwards coffee was served, again in water glasses and extremely strong. So we had a big supper. But in Peto's life it wasn't always like that. Sometimes he ate only once a day, often he got excited about saveloys as they were the most easily digestible meat one could get. So his eating habits varied. But that night there was a big dinner and nothing happened for a long time. We ate without saying a word, I, as a nineteen-year-old youngster, hardly daring to breathe. Later the doctoress stood up and left. Just the two of us stayed. At that moment I already knew that I was in the presence of a lunatic but an extremely fascinating lunatic. Later, though, my opinion of him changed but that's what I thought then and there. The two of us finished dinner and then we were silent. He was silent so I didn't dare talk either. And after an unbelievably long silence, with his unique emphasis he spoke one sentence, something like 'Spinoza was already a taciturn man at the age of forty', I acknowledged this, it wasn't too strange to me as I was studying philosophy at university as well as two other subjects and, although I hadn't learnt that Spinoza was a reticent man, I didn't contradict Petö. And we sat in silence again.

He sat watching or even staring at me and I found that very disturbing. I felt as if he were pushing me, I had a feeling that he goaded me on, there was some sort of pressure radiating out of him towards me. There was even a direction to this goading, towards one end of the room. Naturally I resisted and then he suddenly said

'Why put everything into words? There is the chest of drawers, in it my bedding, would you make the bed for me!'

By then I was ready for anything so I started doing it. There really was a sort of chest of drawers or maybe it's called a commode, I'm not an expert on furniture, there was bedding in it which I took out. There was a sofa. Filled with of trepidation I made the bed. To put it frankly, I didn't understand the situation. When I finished it - with in the meantime Peto" watching what I was doing - suddenly everything turned out wonderfully because he said 
'Thank you, my boy, in twenty three years it hasn't happened that someone made a bed for me with love. Now you go home and I'll see you again next Thursday.'

This was the first meeting. You asked me about it! And then I went home, quite touched by the end of the evening but also quite shaken. I now have a different feeling about that evening, whether he meant it seriously or not and why twenty-three years, but anyhow at the end he won my heart, that it was me who made his bed with love after twenty-three years. ${ }^{142}$

...The official medical establishment really hated Petö, partly because he was an unconventional person. I only realised this later, since I didn't understand it at the time, I only saw that there was an unbelievable hatred around such people simply because of their unconventionality. I think the root cause of this hatred is that people envy the inner freedom of such people who dare to live beyond convention.

Doctor Petö didn't think much of psychology. He could have been right. He once talked to me about the Rose test.

'My boy, this Rose test is only good for one thing on Earth and that is for making money out of it.'

At the time, I was teaching the Rose test to have some income. Another time Petö said: Look, my boy, a test is a substitute for psychology. Lots of people would like to be able to play music well but they are not talented enough. They still play. Lots of people would like to be good judges of human nature but they are not talented enough. They are the people who use tests. If, after a three-hour conversation with a man you still need a test and the result can say anything to you, then you are in the wrong profession: you are no good as a psychologist.'

... When I was nineteen, following the family traditions, I undertook psychoanalysis with Imre Hermann ${ }^{143}$, the doyen of psychologists. I had already been going to him for nine months when somehow András Petö's name came up in our discussion. You should know that I had psychoanalysis at that time because I got married the day after leaving school. I did it to annoy my parents and the girl, who was the same age as me, had her exams at the same time and she wanted to upset her parents too. Anyway, it suddenly grew into a very muddled marriage, which wore me down and this was one of my great worries among other things. And then on one occasion I mentioned Petö's name. Mr Hermann turned his attention to this and realised that I regularly went to Petö. And then he said something about which we argued over even when he was ninety but which swept us apart from each other for the rest of our lives. He told me, a nineteen-year-old boy,

'Look, now you've got to choose'

'What?'

'You can go to Petö or to me for analysis, he answered, but you can't go to two places for psychotherapy.'

'But I don't go to Petö for psychotherapy. He's just an interesting person and I visit him from time to time, and then he feeds me and we have discussions or sometimes we are just silent.'

'No, it isn't like that,' he said, 'he is such a powerful personality that one must be under his influence and that is equivalent to psychotherapy. And one can't have psychotherapy in two places at the same time.'

I didn't accept that. 'Do I have to choose?' I asked.

\footnotetext{
${ }^{142}$ Interview with Professor Péter Popper

${ }^{143}$ Dr Imre Hermann (1889-1984) neurologist, psychologist
} 
'Yes,' he replied. I stood up from the couch and left Hermann, which caused me problems later in my life.

When I next met Petö I told him that Hermann threw me out of his analysis. He was overwhelmed, I made his evening for him with the news. His first question was whether I had always paid Hermann on time or not. 'Because, you know,' he said, 'these analysts are very fussy people.

Then I said, 'Doctor Petö, I paid on time but now that this has happened, this conversation...'

He was overjoyed. 'Look, my boy' he said, 'you were kicked out because of me, so I've got to set things to rights. But why exactly did you go to psychoanalysis? Because you know, I know everything that these analysts know, I just work a bit quicker. You'll see.'

And then I told him that I had a failed, bad marriage, full of suffering and jealousy. Doctor Petö listened to me and I noticed that he had heard enough. He asked me where my wife was then. I said that she was on holiday at Lake Balaton.

'Without you?' he asked meaningfully.

I said, 'Yes, because she's already broken up for the summer holiday'.

He called for a man who used to be an in-patient at the Institute but who had by then been rehabilitated and was employed there:

'Pali, Pali, Pali. Pali, bring a pen and paper for Popper and here is twenty forints. Take a taxi and bring ten fishhooks from the fishing shop.'

Then he turned to me: 'Now write this down, my boy: My dear wife, Zsuzsanna...'

I told him that my wife's name was Zsuzsa, not Zsuzsanna. 'Don't worry, just write Zsuzsanna'. So I wrote it like this: 'My dear wife Zsuzsanna, I've heard that you are having a wonderful time at Lake Balaton.' He went on dictating, 'and you've become a fisherwoman. Enjoy yourself for the rest of your holiday, I enclose some fishhooks! Greetings from your exhusband. Peter.'

I was utterly shocked but I could do nothing. Petö dictated it to me and I had to write it. Pali came back with the fishhooks, we put them in the envelope, sealed it and I posted it.

Then he said: 'Alright my boy, you've finished with the marriage, now let's deal with more sensible things.' And that really was the end of my marriage. Of course, I met the young lady called Zsuzsanna a few more times but on the whole Petö was right, we finished the marriage and dealt with more sensible things.

I learnt worldly wisdom from Petö. He said that one cannot do important things a little bit. This is very important and it permeated my whole life like a chord. He said

'Listen. One cannot do an important and serious thing by halves. One cannot be a little bit pregnant, a little bit syphilitic, a little bit dead. There is no little!'

He asked whether I was reading a book which could be summarised. because any such book is not worth reading. There are things on a certain level and things on a deeper level. There are things which one can only start without hesitation. So, if you are deliberating whether or not to marry a particular woman, then don't marry her. If you can think whether you should have children or not then you shouldn't. The start can only be done unambiguously.

$* * *$

Only three newspaper articles were published about Pető in Hungary when he was alive, in 1949, 1956 and 1963. Three further articles reported his death, in 1967. The press mirrors society's sensitivity and reactions. The importance of different events shows 
clearly what society is interested in and curious about. The first article was published in Szabad Nép, on 23 June 1949. The headline was:

World-wide famous healing - out-of-date Institute. The man for whom the plan is too parsimonious.

The journalist portrayed the situation: children with severe disabilities came from all parts of the country and even from abroad - Romania, Bulgaria and England — into the small Alkotás street Institute. The builders of the new building could not agree on accepting the plans. Construction was delayed. The reason of the delay was that the National Construction Company had been originally in charge of making the plans but then later the Architectural Engineering Company (MATI) was asked to redo them. The original 800,000-forint investment became 1,300,000 forints in the MATI plan, then two million forints. According to new calculations the final figures were 1,500,000 and then $1,600,000$ forints. The article refereed to bureaucratic 'parasites' as the reason for the delays in building. The mood of this article corresponds to the style of the press of that time, which pushed the enthusiastic 'home-building' country and system. The parasites who slow down the building, represent the enemies of the nation. Higher political forces finally solved the argument and, after a year's delay, on 23 February 1950 the new Movement Therapy Institute was inaugurated on Villányi út. There was no report of this in the papers.

Then for a long time, six years, nobody wrote about Petö. The cause was partly that there was no sensational news at the Institute. The Socialistic character was either Stakhanovist or rebellious. In Petö's case one could not report about $120 \%$ or $200 \%$ production because his Institute could not be compared with anything else. There the patients improved in comparison to themselves and not according to a uniform measurement or a stereotyped scheme. On the other hand there were not many papers. There was just one main paper, Szabad Nép, which on 21 September 1956 published an article under the headline 'Visit to the Movement Therapy Institute' reporting on the successful work in the Institute. This was when Petö had returned to work after his recovery and fallen out with Bárczi:

In the Institute patients are treated in a many-faceted, modern way on the basis of modern medical science. The treatment's main tool is movement, accompanied by rhythmic counting, speech or singing.

The article introduced unique cases who had arrived as 'impotent little baggage' and a year later could already walk with their own legs. The article reflected on the harmonic way of working together between parents, children and conductors, natural today but at that time revolutionary.

The third article was published in 1963. An interview was written solely about Pista (Steve), a sixteen-year-old boy, about his life, drawings, paintings and particular selfexpression.

All the articles spoke highly of the work in the Institute, the 'miracles' done there, the conductors' unswerving perseverance and their resolute, self-sacrificing work. Although there were grown-ups as well as children in the Institute, all the heart-stirring stories were written about helpless children who after a few very hard months could dance, look after themselves and throw away their sticks. Although the articles were written objectively, they still touch one's feelings. 


\section{PETÖ'S HERITAGE}

Everybody was very shocked when the 'Great Father of Conductive Pedagogy' was gone but the work of patients and their relatives and the work of students at the college went on. The challenge of living up to the results previously achieved was a millstone around the necks of Mária Hári and the others. Mária Hári faced the problems both inside and outside the Institute with enormous energy, continued Petö's heritage and improved the Institute's foreign reputation. At the Institute education continued. Erik Szauder, who went to kindergarten there in the early seventies recalls his memories of those days:

We had sessions continuously... sometimes we had to complete tasks such as when the motor-disordered children would have to go and fetch their mugs and then get back to their places. It was up to them whether they did this with the aid of a chair, with a stick or with the help of one of the other children. We were given tools to use, which helped. Self-reliance was very important, very much stressed. I don't have many concrete memories from my early childhood, I was wrapped up with myself and didn't take much notice of my surroundings. The cerebral damage didn't harm my intellectual abilities but there were some children in the kindergarten who were really brain-damaged. I could more or less read by the time I was four. ${ }^{144}$

One could try to define Petö's special method from the point of view of an educational and therapeutic system but here we approach Petö's heritage from the point of view of the learners, as did the daily newspaper Népszabadság ten years before Erik Szauder came to the Institute:

Pista can sit.

He eats on his own.

He undresses on his own.

He dresses on his own.

He has read his first book, Be faithful unto death ${ }^{145}$.

He holds a pencil.

He starts enunciating clearly.

He takes two steps holding on to chairs.

He connects marked-out points on paper.

He marks out the points on his own and connects them.

He draws lines without the points.

His first letters.

He takes his first step on his own.

Ten steps on his own.

He made a motor ...he wants to be a mechanical engineer.

He finished Class $V$ with outstanding results.

And between the notes there were of course months and years. And how much effort from the conductors, care, science and love. ${ }^{146}$

\footnotetext{
${ }^{144}$ Interview with Erik Szauder

${ }^{145}$ Zsigmond Móricz: Be faithful unto death, 1962, Corvina

${ }^{146}$ Népszabadság, 23 December 1963
} 
Back in 1986 a report was written by the Ministry of Health:

Considering that the Ministry of Health regards that the Petö Institute belongs to the Ministry of Culture and Education only from the point of view of training, it therefore feels responsibility for the rehabilitation of motor-disabled children and tries to help with all kinds of improvements. The reticence of the Institute's director raise certain inconveniences which can be explained on one hand by the tribulations of the school's founder, her predecessor András Petö, and on the other hand by the medical establishment's aversion to conductive pedagogy. Nevertheless, as the work of conductors and remarkable devotion becomes more widely known, acknowledgement of and need for the Institute also grows greater and greater. $^{147}$

In the same year the highest political leaders, including János Kádár ${ }^{148,}$ were informed about the operational conditions of the Institute and the expansion of its activities: ${ }^{149}$

1. It can be ascertained that the new situation of the Institute on Kútvölgyi street and renovation of the old premises provide for the requirements in the capital and training of the so-called conductors. There is need to establish a few new wards on the capital's Pest side as well. The City Council has promised to hand over a few crèches and the take-over can be realised in 1987.

2. The Ministry of Culture and Education which is in charge of the supervision of the Institute could not envisage development of the network to cover the whole of the country in the seventh Five-Year Plan. Therefore, in co-operation with the Ministry of Health and the counties, certain improvements can be provided with the aid of local resources and social collaboration in hospitals and children's institutions. In such a way, in Kiskunhalas a conductive therapy ward has been established, and in Miskolc, Tatabánya, Szombathely, Györ, Eger and Debrecen, preparations have been made to set up such sections.

3. According to the Director of the Petö András Institute, in five years time they would be able to train specialists for two-hundred in-patients and for the associated outpatients' section. Comrade Medve sees a reasonable possibility to set up a two-hundred-place accommodation and associated outpatient ward.

The promised new Institute in Kútvölgyi street was a long time in its building, opening only in 1885. By the end of this drawn out construction, it had cost 280 million forints. It was named after Petö. There were in-patient wards for three-hundred children and outpatient wards too. More recently the old Institute in Villányi út was reconstructed, completed in its new form in 1998 to provide residential education and accommodate conductor candidates. In 1999 the number of adult outpatients is six hundred and child out-patients twelve hundred. There are residential pupils in the Villányi street Institute and two hundred and twenty in the Kútvölgyi street Institute. There are another one hundred and twenty foreign children. In the Training College three hundred and twenty students study with forty full-time teachers. The previously

\footnotetext{
${ }^{147}$ László Medve: Report on the circumstances of the Pető Institute. Budapest, 16th June, 1986. pg. 6.

148 János Kádár (1912-1989) Minister of Home Affairs (1948-1950), Prime Minister (1956), Minister of State (1958-1961), Prime Minister (1961-1965), Secretary-General of the Central Committee (1985-1988)

${ }^{149}$ Lénárd Pál’s notes to János Kádár PL/310-2/1986
} 
promised countrywide conductive pedagogy network did not materialise according to the original plans but the Institute lays much emphasis on international relationships and it accept specialists and students from abroad. The first two important contacts were the English and the Japanese but the whole world has now caught up (Israel, New Zealand, Germany, Austria, USA and so on). Today Petö's heritage is international public property but that it has been safeguarded and developed is to the enormous credit of Petö's excellent colleagues who worked in their particular fields conscientiously and with a sense of vocation, and above all kept Pető's spirit alive. Pető's life work has grown to full stature and become an international treasure, with institutions all over the world. Specialists in Conductive Education and other fields contribute more and more as knowledge develops.

We could say that this is Petö's life-work and it speaks for itself. 



\section{BEYOND MEDICAL SCIENCE}

Already as a young man Pető was interested in Eastern religion and meditative thinking, and in everything closely related to it, health, body, self-knowledge and self-healing. László Horváth remembers:

Then dinner was served and we talked of many different things, for example we spent a good while discussing Eastern medicine. He said to me, 'We should send someone to China to learn acupuncture.' I said that I wasn't exactly dying to go to the People's Republic of China but I would like to find out about acupuncture somehow. Even if not in practice it would be good at least to know about it in theory. If I prick certain points, I see phenomena that are hard to understand according to current medical thinking of the day (this was in the nineteenfifties). Then he showed me a diagram of a fat Chinese man sitting cross-legged with various points marked on him. Among other things, there was a point in between two incisors and pricking that made gallbladder pain go away. I somehow could not understand that.

'You have to prick in here?'

'Yes, it is written down,' he answered.

'But what is the nerve connection?' I asked.

'I do not know, said Petö.

Later, I was called out to a case, an old lady, on the second day after Easter. Well, they had eaten too much, she had a bilious attack and I had absolutely nothing on me. I asked for a knitting needle, I took it and poked it into the indicated point and her pain ceased immediately.

Petö wasn't excited by the religion but rather by the several-thousand-year-old healing methods of Chinese and Hindu acupuncture and acupressure that was based on folk traditions... if one but heard the word acupuncture in those days one just smiled. But when I had a real experience of the pressure relieving the cramp like that it impressed me greatly. ${ }^{150}$

Miklós Kun also knew Pető's mysticism:

He believed a hundred percent in reincarnation. And he was positive a certain circle would reincarnate together. To this circle belonged Radnóti, Gönczi and myself. This was a fully formed idea of his. He wasn't a healthy man and he explained to me more than once that he would not live a moment longer if he wasn't absolutely sure about reincarnation. As I said, he was good at everything. He knew homeopathy, he knew medicinal herbs. During the war he was mostly buried in libraries, studying mysticism. He studied Jewish, Islamic and Christian mysticism, as well as Hindu. To return to Petö, I don't know how much he used the Viennese Moreno's technique within his own. Once I lent him a book by Kurt Goldstein, an excellent brain physiologist, and he said to me: 'This is my own thought.' In other words, he had nothing to do with anyone, he thought nothing of the others. He had no predecessor or ancestor, he worked his method out from his own head. Maybe it was Tibetan medicine that he based it upon. He had a Tibetan method too: This meant pronouncing the vowels á,é,i,o,ú in a way that when you say 'a' your head resonates, with the 'e' it resonates at the end, with the ' $u$ ' beforehand. And this has to be practised. He kept himself busy with the science and mysticism of Tibet but not with any traditional European methods. Once he told me how a member of the Political Bureau of Bulgaria came to him when he was ill. He was staying in one of the Party's week-end houses. Petö went out to him every day trying to cure him but it did not work. But

${ }^{150}$ Interview with Dr László Horváth 
once he had a thought and said: 'Now while doing the exercise, say 'mangragura', and it worked. He was a productive genius. ${ }^{151}$

Tamás Vekerdy mentions another strand:

Petö was a student of Rudolf Steiner's work. He had studied it for long time. He knew his philosophy, his pedagogy and his curative education. Petö carried Judaism and Christianity within himself but in his manifestations he showed himself to be most closely related to Buddhism. He would suggest books to read on this topic. ${ }^{152}$

Ilona Székely remembers that he believed deeply in the truth of Eastern culture: ${ }^{153}$

I also had to study it although I couldn't really understand it. There was Buddhism in it and lots of other things from Eastern religion. He believed in a lot of things, he explained the importance of the phoenix ${ }^{154}$ to me, he talked about that a lot. He believed in reincarnation. Many people have misunderstood Mária Hári's devotion to doctor Petö but he always said:

'Listen, Marika, try to understand that if I cease to exist then I will enter into someone as a phoenix, maybe into you, Marika'

This has remained prominent in my memory because I found it very interesting. I believe that Petö did not believe in his own strengths. He believed that there were sometimes forces at his disposal if he had to heal a particular patient in whose destiny it was written that he would be healed. I also felt that such forces really were available to him. But he did not believe that the force was his own, rather that it was some superior, cosmic force. He himself was a very fallible man. And it was also something fantastic and incomprehensible to me that sometimes his placidity would be replaced by an enormous rage and he would literally shake with anger. He really was like an Oriental Magus. He was frightening. This man could be an ascetic who ate only once a day, one piece of saveloy, and at other times he could take gluttony to its extremity. But I think he suffered because of this. He could hardly come to terms with his own intense emotions and his extreme hot-headedness. ${ }^{155}$

Foreign acknowledgement has brought Hungarian success. One of the reasons can be explained as follows. Medicine, which used to be considered an art in the ancient world, has become science over the last two centuries. The bio-medical view displaced the understanding of the unity of body and soul. The language of European medicine became patho-physiology and its foremost representative was the second Viennese medical school (1800-1840): every illness's diagnosis was proven in the dissecting room. But diagnosis itself was not enough for healing, science's level of development at that time did not improve further. Without recognising pathogens, without adequate therapeutic treatment and medicine, a nihilist view was formed. In the middle of the twentieth century Western European countries noticed the crisis of traditional medicine sooner than did the rigid Socialistic medical system. The petrified philosophy of the regime and dialectical materialism allowed nothing in healing which was not based firmly upon provable, measurable facts. Before the 1960s psychology, sociology, sexology and holistic science were not accepted as sciences in the Socialist camp. The official,

\footnotetext{
${ }^{151}$ Interview with Dr Miklós Kun.

${ }^{152}$ Tamás Vekerdy: Álmok és lidércek, Budapest, 1992, T-Twin

${ }^{153}$ Interview with Ilona Székely

${ }^{154}$ Phoenix: An Egyptian and later Greek and Roman mythological bird, which arises renewed from the ashes of its own cremation.

${ }^{155}$ Interview with Professor Péter Popper
} 
conservative health authorities considered Pető's new and great erudition as 'heretic' and did not let his curative and educational method blossom. He himself was believed to be a swindler and a charlatan. Károly Ákos reminds us how antithetical were the times ${ }^{156}$ :

After 1948 there was no psychology here as such. Lajos Kardos was the only official psychologist. The psychoanalysts only analysed. Dr Gegesi founded a psychological society in about 1960.

In medical society the first to accept Petö's scientific interpretation, justification and success were those such as Szentágothai and Donáth who were involved with brain anatomy and physiology. Most Hungarian doctors could not bear dogmatic thinking and tried to make it impossible. Only towards the 1990s did society and medical circles start turning towards holistic medicine. Alternative treatments have all kinds of names, alternative, natural, holistic, heterodox, traditional, additional, irregular, naturopathic, etc. However we call it, they are all based upon faith in nature's healing force and are as much life-style reform and education as healing.

The change of paradigm is not associated with Peto's name but we can consider Petö's method forerunner to the contemporary, non-medical, positive mental hygiene of Gordon. It puts health and illness on a different basis and approaches the problems with a bio-psychosociological and holistic attitude. We can see this in the change of terminology:

there is no stigmatisation;

we say client instead of patient:

we use dynamic process-analysis instead of a causal approach;

instead of therapy and healing we have education and mutual learning.

It is not the doctor or physiotherapist but the conductor who leads towards self-reliance.

${ }^{156}$ Interview with Dr Károly Ákos 



\section{INTERVIEWS}





\section{DR MIKLÓS KUN"}

It is rather a long story how I got to know Pető. My friend, Miklós Radnóti ${ }^{158}$ introduced me to Dr László Gönczi ${ }^{159}$, who had come home to Budapest from Vienna and was then the husband of a rich landowner. He was a well educated and cultured man, but despite this, he was worried about the growth of Hitlerism. He was continuously telling me that he was going to be killed. When I had had enough, I told him to leave here if he was so afraid. And he did study microphotography, so that while his diploma was being validated in France, he could make a living from histological microphotography.

\section{What kind of a degree did Gönczi have?}

He was a medical doctor. His sisters were Anci Gönczi, the kindergarten teacher, and Terka Gönczi, who is a psychoanalyst and lives in America now. The three of them, the Gönczis, are a family from Szeged.

So Laci Gönczi went to Paris leaving his wife and small child behind, thinking they would come after him once he had established himself there. In Paris he made friends with Petö. A week before the outbreak of the war, before Poland would have been attacked (in 1939), Gönczi's wife went to Paris and brought her husband back. Pető came with him. I met Pető at Gönczi's.

At that time I was working in Lipót Szondi's ${ }^{160}$ laboratory with Ferenc Mérei ${ }^{161}$ and Flóra Kozmucza (that is Mrs Illyés), and on top of that I had a private practice in my flat. And so I met Petö, who was quite repulsive looking, he was fat and pyknic.

We were talking of different things when he asked me: 'What are you reading at the moment?' I said the latest Thomas Mann book. To which he said: 'You are reading such obsolete books?' This man is crazy, I thought. 'What should I read then?' I asked. He said: 'Kafka.' 'Who is that?' I asked. 'Read either Schloss or Der Prozess, he answered.

He is mad, I thought, but I browsed through the used bookstores on Museum Boulevard, and in one of them I found Der Prozess (The Trial). I read it.

Afterwards I immediately went out to Laci Gönczi, he lived in Hüvösvölgy and Pető was staying at his house. I went up to him and apologised. 'I apologise to you,' I said, 'because I thought you were talking nonsense, but I now realise you were right.'

He was right, because The trial is about prosecution, which was the essence and motif of that period.

I asked Lajos Pók, ${ }^{162}$ who wrote a monograph on the works of Thomas Mann and Kaffka: 'What is it in which Mann comes second to Kaffka?' To put it briefly, he was of the opinion

\footnotetext{
${ }^{157}$ Retired Vice President of the National Psychiatric and Neurological Institute, recipient of the Officer's Cross of Honour of the Hungarian Republic

${ }^{158}$ Miklós Radnóti (1909-1944) poet, translator, member of the College of Young Artists of Szeged. Works for 'Nyugat.' He was shot by the Fascists in forced march.

${ }^{159}$ László Gönczi, medical doctor (Szeged, 1901-1944) He was killed in forced labour.

${ }^{160}$ Lipót Szondi (1893-1986) neurologist, psychiatrist. Leader of the Biological and Pathological Institute of the College of Special Education. He left Hungary in 1943 because of the prosecution of the Jews. He went to Switzerland and to America. Founded a new school of depth psychology called 'faith analysis.' His tests of instinct diagnosis are used in psychiatry.

${ }^{161}$ Ferenc Mérei (1909-1986) child psychiatrist.

${ }^{162}$ Lajos Pók (1919-1998), literary historian, director of science section at Gondolat publishers, author of monographs on Goethe, Thomas Mann and Kaffka, edited the Small Encyclopaedia of World Literature.
} 
that Thomas Mann was the ending, the culmination of the beginning of the 20th century realism, while Kaffka brought a new way of depiction.

Yes, this is exactly how it was. So I became friends with Petö. He asked me, since I was seeing patients in my flat from 3 to 5 , if after 5 he could give courses on movement therapy for nurses and care-givers.

Though in Austria he worked for the Doctors' Weekly, he was good at everything, at movement therapy as well. No-one knows how this got started. He was a universal genius.

He believed a hundred percent in reincarnation. And he believed that a certain circle of people would reincarnate together. To this circle belonged Radnóti, Gönczi and I myself. This was a fully formed idea of his. He wasn't a healthy man and he explained to me more than once, that he would not live a moment longer if he wasn't absolutely sure about reincarnation.

Before the war he lived at the Gönczi's for some time, and then he moved to a printer called Dániel Bródy. He was a descendant of the great writer family, they had a big flat and gave one of the rooms to Petö. Mrs Bródy, his wife, had chronic back-ache that nobody could even ease, but Petö healed her. It was Mrs Bródy who took care of Petö, and I think it was her he later fell in love with. The house-keeper cooked for him.

He invited me for supper once a week. This would usually be as follows: Pető hardly ate at all, but they kept bringing different courses to me. He would shout at me: 'And now you will eat this!' He was an independent, self-willed man.

As I said, he was good at everything. He knew homeopathy, he knew medicinal herbs. During the war he was mostly buried in libraries studying mysticism. He studied Jewish, Mohammed and Christian mysticism, as well as Hindu.

Once I had a patient who had multiple sclerosis and one of her legs was so distorted, that it was bent at the hip and at the knees. Using one leg, she could not walk. I put her into the neurology department where she got worse and ended up weighing only forty kilograms. I asked Petö to treat her, he used movement therapy and after two months my patient's leg became straight and she answered the door for me herself.

Then the Hungarian nazi regime, the swastika came. The International Red Cross where I was senior doctor had a B-section, a representation of the JOINT really. I heard of Auschwitz in the spring of 1944. I had an acquaintance, Miklós Klein, who worked at the Swiss Embassy, and he told me there were records, that someone who escaped from there wrote down what was happening in Auschwitz. That was when I had the idea to establish children's homes, to at least save the children. It was similar to what Margit Schlachta did to save children.

I went everywhere, I went to the Swedish embassy, to the Papal Nunciature and to everyone else, but nobody wanted to talk to me, they said the time was not right. Finally I was advised to go to the Zionists. I contacted Otto Komoly, ${ }^{163}$ who was the leader of the Hungarian Zionists and he told me to look up the B-section of the Red Cross. That was when I started to organise the children's homes.

I worked as a child psychiatrist under the leadership of Júlia György, in the child-welfare centre. I succeeded in tiding 300-400 children over the hardships of the war in children's homes in Buda.

Later, after the war, there were huge arguments concerning the protection and welfare of children. We wanted to place them out with families, but in party circles they were against this type of care.

\footnotetext{
163 Ottó Komoly: President of the Hungarian Zionist Union, engineer. The Union had a threefold goal: to save Jewish lives across the border, to support refugees and to prepare the self-defence of Hungarian Jews. R.Braham: Hungarian holocaust, Vol I. p. 91. Budapest,1981. Gondolat
} 
Our greatest problem was the infants. With my friend László Dobszay, who was President of the foundling hospital in Pest, we placed the infants out with child-loving women who owned flats and whom we found through advertising in the newspapers. We checked them and prepared them for bringing up the children beforehand.

This kind of community care system worked really well, until one fine day Anna Ratkó sent for me and said: 'Comrade Kun, you are supporting the bourgeois, 'and she listed the names of the wife of a Lord Lieutenant and of a chief counsellor whom we had educated. I told her we were not supporting the bourgeois, but saving proletarian children, and that those people owned flats, nor were we going to place out the children in one-room proletarian flats.

It was an ideological problem, and I was even reported to the police for it, that in the Home for Juvenile criminals in Rákospalota, opened by Mrs Mihály Károlyi ${ }^{164}$, there were pictures of saints hanging on the walls ${ }^{165,166 .}$ I went out there to see them: they were renaissance pictures. Works of Botticelli and of other great artists were hanging on the walls.

To return to Petö, I don't know how much he used the Viennese Moreno's technique in his own. Once I lent him a book by Kurt Goldstein, an excellent brain physiologist, and he said to me: 'This is my own thought.' In other words, he had nothing to do with anyone, he thought nothing of the others. He had no predecessor or ancestor, he worked his method out from his own head. Maybe it was Tibetan medicine that he based it upon. He had a Tibetan method too: This meant pronouncing the vowels a, e, i, o, u in a way that when you say 'a' your whole head resonates, with the ' $e$ ' it resonates at the back, with the ' $u$ ' in front. And this had to be practised.

He kept himself busy with the science and mysticism of Tibet, but not with any traditional European methods. Once he told me how a member of the Political Bureau of Bulgaria came to him when he was ill. He was staying in one of the Party's week-end houses. Pető went out to him every day trying to cure him, but it did not work. But once he had a thought and said: 'Now while doing the exercise, say: 'mangragura', and then it worked. He was a productive genius.

Pető was an astute businessman as well. For example he told me how once in Vienna he had been sitting in his usual coffee-house when an acquaintance of his came up to him. He offered Petö a kind of powder which when put into water started to fizzle. Meanwhile the owner was complaining that in such hot summer weather he was running out of beer. To which Pető answered: 'Give me a piece of paper and I'll write you a prescription which will never run out.' He wrote the prescription out, it worked, and afterwards he got a monthly allowance. It became his main source of income.

Then later in Budapest at the time of the Jewish laws, he had a lady-friend who was managing a textile company. They met daily and Petó gave her hints how the company was to be managed. So Pető was a law unto himself, a unique individual.

\footnotetext{
${ }^{164}$ Count Mihály Károlyi (1875-1955) democratic, liberal politician. President of the Hungarian republic in 1919. He distributed his lands to the people of the country. He returned to Hungary after the second world-war. He was referred to as the Red Count. His wife, Katinka Andrássy, followed the liberal-democratic and anti-Fascist ideology of her husband.

${ }^{165}$ Remembering the decades of domestic children and youth welfare after the liberation. In Gyermek és ifjúságvédelem 1986. Vol. 1 pp 31-33.

${ }_{166}$ There were street-boys and abandoned children among them, whom we found like this: ..Once in a train we found 30-35 children. They had identification sewn onto their clothes, such as: 'Said to be: Sándor Szabó, supposedly 8 years old.' They had been locked in the train for five or six days without food or drink, and nobody knew where they had come from, nor where to they were supposed to go, or why they ended up in a cattle trucks. (Dr Ferenc Gáti: Remembering the decades of domestic Children's and youth welfare after the liberation. In Gyermek és ifjúságvédelem 1986. Vol I pp 34-35.)
} 
I am sure Pető had no doubts about his ability to heal disabled children. He made them exercise from morning to evening, and he was able to achieve a lot with them, even children with Heine-Medin or multiple sclerosis. He had the great idea to put the beds on top of each other in the bedroom during the day, and in this way he got a huge exercise-room, enabling him to work with one hundred children in a fifty bed institute.

As to his colleagues, I know he liked Károly Ákos, who was a neurologist and put together a series of exercises based on Petö's. The conductors did not learn out of a book, they learnt by example. A year ago the Academic Publishers sent me a book on the Petö-method to review, it was edited by Mária Hári. However, before I could give my opinion, Hári withdrew it from the publisher and it never got published.

Pető had very few works published. In 1952 he wrote an article on Soviet neurology, but he never wrote about his method. He practised that instinctively. Somehow it was hard to give a scientific basis to intuitive feelings. Now Hári and the others are trying to pass the examples they learnt on. What was productive genius in Petö is now being fixed by Hári, as far as I can see.

We have no connection with Hári, ... I used to see her in the Institute every now and then. At the opening she asked me to give a speech, but I don't like to make a show, so I refused to do it.

I started as a neurologist. I spent 3 years in the neurology department of a hospital, and I fell out of love with neurology. Mérei was a good friend of mine, he worked at Szondi's, and it was he who told me to come over to Szondi as well. He was leader of the biology laboratory at the College of Special Education. I stayed at Szondi's until in 1939, because of the Jewish laws, both Szondi and I had to leave. Then together with Mérei I went to Júlia György, to the children's shelter of the Jewish Union on József Boulevard. When I was called in for forced labour service, I gave this job to Laci Gönczi. Later he was called in too, and he was killed. So this is how I became involved with children, by chance.

I had a chequered life. I earned my doctorate at the Neuro-patholgical Clinic in Lipótmezö, I became vice-founder of the Hungarian Institute for Alcoholism, and I also directed it. I was editor of the periodical called 'Alcohology,' I retired at 72. Now I am 83.

I retired, and now I am a scientific advisor for the Neurological Board in the Ministry of Justice. And I still go to the Neurological Board three times a week.

\section{To return to Petö, how much did he believe he could heal the patients.}

He was absolutely positive that he could make them fit for life. Even if not a hundred percent, but he would teach them to speak, walk and eat, to be able to live as a human being. He didn't doubt this for one moment, and he always found some possibility. However, he never tried to gain financially out of it.

Petö started his career with physiotherapy, and I believe he ended up with motor disabled patients by chance, which is not a bad way at all. He could have come upon something else and then he would have done something different and been a genius at that.

Just one more thing about him, he subscribed to all kinds of foreign magazines, since he read German, English and French fluently. And he also had many, many foreign connections.

Well, those are the things I had to tell you about Petö. 


\section{MRS IMRE ÁGNES KENYERES}

What Pető did, right from the beginning, could not be compared to anything or anyone in Hungary. His method and concept were a unique philosophical thought.

I must start the story of my acquaintance with Petö with my husband, Imre Kenyeres, who was born in 1911. He became a teacher's assistant at the University, he was studying literature at the Faculty of Fine Arts and worked for the university press at the same time, edited Diarium newpaper (1934-1948). We married relatively young, we met at the university and when we got married we already had a reasonably stable financial background with a good salary.

He wasn't only exceptionally bright and cultured but he was also handsome and sporty, a completely healthy man with a sure walk. Every now and then he complained that his legs and his knees hurt, but said that he had got a cold.

In 1939 my son was born, and he was also completely healthy. Two or three years passed and my husband's leg started to hurt more and more. The doctor recommended hot baths, so for two years he visited Hajduszoboszló while our son and I went to the Mátra hills.

During the war from ' 41 to ' 43 my husband wrote me letters all the time, he was a graphomaniac, and I noticed how his handwriting, which used to be very beautiful, readable and intelligent, deformed and was continuously deteriorating. I became frightened. A friend of mine, Magda Radnót, was an optician and I told her about it. She was quite fond of Imre, and she became worried that his writing had changed and deteriorated. She arranged for him to be examined at the eye clinic and from the spinal cord examination they concluded it was multiple sclerosis. Another friend, Marianna Mándy, recommended an acquaintance of hers, a man of rare genius by the name of András Petö, who had just come home from Vienna. She promised to put in a few words on my behalf, though he was a difficult man.

Imre was living in perfect intellectual health, he wrote very good articles. It was difficult for us, but in ' 43 we finally went to Petö. He lived at the time in the house where the memorial tablet is now. On the second floor lived Aurél Bernáth the painter, who was my very good friend.

Petö's apartment was a kind of a monk's flat: two rooms, simple furniture, a bookshelf and in the other much smaller room, a bed. I remember this peculiar looking man perfectly, he wasn't friendly at all. He asked Imre to go in and I sat in the other room for a long time. Later Petö came out and said: 'This is a fine man. I am going to heal him.' This is how it started.

Petö said Imre could work in the mornings as usual, but had to lie down in the afternoons. He gave us drawings and prescribed arm and leg exercises that were linked to breathing. The interesting thing was that he never spoke of the illness or the treatment after this.

When we first met him he paid no attention to me whatsoever, but later in 1942-43 a great friendship grew between us, and we got closer to each other. He found a liking for my son, Zoltán, he was a sweet little child. In the theatre Pető always went to first nights or dress rehearsals while we visited the evening performances.

I am going to heal him, Petö promised. My opinion is that this would have happened had the war not broken out, which Hungary joined, causing our lives to become more and more difficult. This was especially the case for Petö, who was being persecuted and in " 44 he had to put on the yellow star. Also, the strict rules and prohibitions restricted his free movement a great deal. That was the tragedy, that in ' 42 and ' 43 he was still treating my husband, but in ' 44 this lessened to the minimum. The exercises we were doing in any case. I still have a tram

\footnotetext{
${ }^{167}$ Belletrist, compiler of the Hungarian Encyclopaedia of Biographies.
} 
ticket which my husband and Pető used to come to my house around this time. Petö gave me the ticket and told me to keep it because it proved that Imre was able to step up onto the tram.

At that time Petö was treating people with this type of illness in Hungary. It was always him coming to our flat, but he never even accepted a cup of coffee. I got to know that side of him too: when he said something, then that is how it was - end of discussion. If he doesn't want a drink, then he doesn't drink. After the treatments we would have conversations, and since he was very interested in literature and we were both people of literary minds - I was writing and my husband had published a book, - we had things in common to talk about: theatre and newly published books. My husband ran a monthly newsletter, but it was discontinued in '48. Afterwards Imre was left without a job because of his illness.

But I'm getting ahead of myself. In 1943 Imre was still walking. The tragedy started in '44 and it is my strong conviction that he would not have ended up in the condition he did, had things happened differently.

In March 1944 the Germans took over, Petö couldn't move around freely, then the yellow stars had to be displayed, although he never actually wore his. I knew someone was taking care of Petö, I mean they were hiding him. Here, maybe, I could blame myself again, but I will not, because there were terrible bombings and only someone who has experienced it for themselves can know what it means to go down to the bomb-shelter from the third floor with a paralysed man and a small child.

So all I knew about Pető was that he was relatively safe. Later I heard from him that the man who was hiding him in his apartment was on Margit-bridge when the bridge was blown up, full of vehicles and people. The man died in the Danube and Petö was left in the locked apartment. His escape, that he somehow lived through this and stayed alive is simply a miracle. He only said that it was his friend, Miklós Kun, who rescued him.

In January of 1945, after the liberation, Imre's condition hit rock bottom. After all we were in the basement for seven weeks... The other tenants helped, but it was terrible even for the healthy, let alone for an ill person and he was practically paralysed when he was brought up from down there.

There was no news of Petö yet, we were searching for him with the help of Mariann. Some time passed before we found him, or actually it was him who gave a sign of himself, and I saw how shocked he was when he saw Imre, but he continued the interrupted treatment.

And there was a second tragedy: my mother-in-law. She did not like Petö, unlike my parents who loved him and he in return liked them. My mother-in-law came once saying she had met a Polish doctor, a miracle man, who healed this sort of paralysis completely and that she would like him to treat Imre. I was unwilling, but I agreed to it.

Due to some miracle we still had all our possessions, even my jewels, but all of it was spent on this doctor he asked so much.

Pető on the other hand didn't accept a penny. When we first asked him about his fee he made a gesture with his hand that meant, that it could not even be brought up.

The Polish doctor did a lot of harm, because he had no idea what he was doing. Petö found out about it and got very upset. Maybe he understood something, because he didn't bear any resentment against me or Imre, but rather against my mother-in-law.

So for more than a year, ' 44 , ' 45 and ' 46 , he received no treatment from Petö. Meanwhile I found out from Mariann that Petö had been inquiring after us.

In the autumn of ' $45 \mathrm{I}$ had started working at the Ministry of Housing, through the Bourgeois-democratic Party, where one of the movers and shakers was Gábor Kemény. He was organising a department for educational affairs and he invited me to be an official there. 
Later Dezső Keresztury ${ }^{168}$ became Minister, but the winds of change were already blowing. Then came Ortutay ${ }^{169}$ from the Smallholders' Party, with whom we were good friends, since my husband's company published his collection of ballads.

Our circle of friends consisted of young people from the town of Szeged, and till '48, while Imre was still able to sit up, I was always inviting people to our home.

In the Ministry of Culture I worked with Fifi, a good friend of mine from our childhood, who was the wife of the great Hungarian poet Miklós Radnóti. During the war Radnóti was taken for Nazi forced labour. Once in our last conversation together while visiting home, after we had been to a concert, Radnóti asked us to take care of his wife, Fifi. Radnóti was killed in the war, and he was buried in a mass grave. We met Fifi again only after her husband's exhumation. Once she fell ill and she couldn't swallow or couldn't salivate, but she went to Petö and he treated her successfully.

So Fifi started mentioning Petö. I said I would go to him as well, breaking a silence of two years. Petö was extremely understanding, I cannot put it any other way. He even hugged me, though he was not that type of a man, and somehow his movements were such as if he were telling me not to mention the whole thing at all. He asked me how Imre was doing. We agreed that the Polish doctor was a charlatan. So in this way our connection to Petö was picked up again. He told us about his life after '45, how the group of doctors around Simonovits ${ }^{170}$ was very much against him, they were questioning whether Petö even had a degree in medicine.

I don't know when his connection to the Institute of Special Education, where my husband was once treated for 3 months, ceased.

He was persecuted from all directions; he had enemies, terrible people. I do not know many names, I remember Simonovits because Pető mentioned him so often, but there was a whole group behind him, who made Pető seem like a witch doctor. This is when he conceived of the idea that he had to found an institute for movement therapy, this is when it all started. Though without any great power, I stood behind him completely. Zoltán Zsebők ${ }^{171}$ of the Smallholder's Party or Peasant's Party and György Alexits ${ }^{172}$ were under-secretary at the time and I asked him to support Pető. Fifi carried the Ortutay line completely, and in this way the building of the Institute started.

That the Villányi street Institute was born was not only due to my participation, it was due to Fifi's as well. There were financial problems and all sorts of other affairs, I don't remember all the details, but we had to fight in meetings if money was needed. The Institute was created around the end of the decade.

In 1956, during the revolution, Imre was in the Petö Institute thanks to some divine miracle, because nobody had the faintest idea of what was to come. He spent the whole autumn there and came home sometime in January. Pető had already told us that Imre would go to spend his summer holiday there. It was virtually free, as well, we had to pay something to the Council, but to no one else. They treated him there for 6 weeks at a time, sometimes even for two months.

\footnotetext{
168 Dezső Keresztúry (1904-1997) teacher, writer, poet, translator of literature, Minister of Culture, Education and Religion 1945-1947

${ }^{169}$ Gyula Ortutay (1910-1978) ethnographer, collector of folk-tales, museum director, Minister of Culture, Education and Religion 1947-1950, Deputy chairman of the Cabinet 1963-1965

${ }^{170}$ Dr István Simonovits (1907-1985) Correspondent of the Hungarian Academy of Science. 1957-1964 Deputy Minister of Health.

${ }^{171}$ Zoltán Zsebők: (1908-1984). Professor of Radiology, Secretary of State for Health.

${ }^{172}$ György Alexits (1899-1978) mathematician, under secretary of Religion and Education Ministry in 1945-48
} 
I was in constant contact with Pető. I was on friendly terms with the conductors, including Mária Hári. Though he was already in bad condition by around ' 55 , Imre never lost touch with the world, he was intellectually sharp. He was writing critical essays for Magyar Nemzet. At that time Peto visited only every two weeks. One of the things that entertained Imre was to have hour-long phone-conversations with Mrs Tersánszky Sári Molnár, who was also ill with a kind of paralysis, or with Mrs Babits Jolánka, but his hearing started to deteriorate. I told this to Pető, Mária Hári was also aware of it, and they were looking at his ears. I said to him: 'Doctor Pető, if Imre goes deaf, I will poison him.' After a short pause Pető said: 'I once had a patient in Vienna who had lost all other facilities, he could only move his eyes. He had a typewriter and his wife typed whatever key he looked at. He published a book that way. And now get out of here!'

Afterwards I called him on the phone many times, but he was always busy. Then finally he sent word that he was expecting me for supper. From 1959 on I was invited to his house for supper once a month. He had a housekeeper, the table was always neatly laid. He usually ate lobster or snail, at that time there wasn't much to eat at all, but on a plate there were three slices of meat with gravy and I ate one of them. 'Thank you, doctor Petö, I couldn't eat more.' Then he told me to eat them all and would not accept a rejection. When he left the room for something, I put the leftovers into my handbag, which he didn't notice. Afterwards we ate that meat for three days. I would always take some butter-paper with me and take the food home. He never noticed it. More than once I wanted to give him something in return, but he wouldn't let me. Then once I was invited on Christmas afternoon. There was nothing there, I just sat down and we talked. I had brought a bottle of wine and asked him to accept it. He said: 'Before you came, Olga Szentpál ${ }^{173}$ was here. She drew me a Christmas tree with birds around it. That was a gift, this is not a gift, take it away.'

\section{How did Olga Szentpál meet Petö?}

Probably because she was a movement artist. I was close to Olga, but we didn't especially have conversations about

Petö. However, we certainly agreed that if you had to make a priority-list of all the people in the world, András Petö would undoubtedly be at the top.

Whenever Petö had any sort of a problem, he always called 'Aunt Olgi' and she fixed everything. Once, when he was about to be fired, Aunt Olga interceded with Ortutay for Petö's sake.

Perhaps... I don't know much about these things, but I would like to mention one name: Erzsébet Andics ${ }^{174}$. She had some sort of a motor disorder and Petö treated her for a short while, but you know, he was the kind of person who never accepted any money from anyone.

Andics told Petö that there was a man working in the accounts department of the Party who was either paralysed or lame. She asked if maybe Pető could do something for him. He succeeded in improving his condition to the point where he was able to do his work.

Petö always managed to get all the foreign magazines in English or in French. Once he had read them, he sent them over to my son. So I said to him once: 'Look, doctor Petö, I have nothing to give you, please help me... What could I do for you in return?'

\footnotetext{
173 Olga Szentpál: (1895-1968) Pianist, dance teacher. She studied movement art at the Delcroze College in Hellerui. In 1944 she founded a school of movement art, which Ortutay's wife also attended.

${ }^{174}$ Erzsébet Andics: (1902-1986) Member of the Hungarian Academy of Science. Kossuth Prizewinning Historian, Communist theoretician
} 
He told me that there was a man named János Faludi working in the School of Fine Arts since 1956, when László Cs. Szabó had been fired. I knew Faludi from my higher education times. The students didn't like him so much, because his lectures were boring, - unlike those of Géza Hegedüs — but nevertheless he was a good and cultured man. Well, he left the country and with it his mother, but when he got to the Austrians he changed his mind and turned back for home. However, he died on the way back, leaving his mother completely alone. 'Send her 200 forints.' Petö told me. There were others who gave as well, and in that way he was helping her.

I will go back to that invitation which occurred in 1960. Petö was sitting there and reading a huge newspaper in Hebrew. He just continued reading, and this went on for another 10 minutes. Finally he started to speak about literature and other things, and then he dropped one sentence:' Imre is not going to go deaf.' And then he went on with the previous subject. That was it.

My husband died in '62 in the hospital in Szeréna street. Petö visited him once, and I think Mária Hári did as well. I went in one day, when he was already very weak. He had the earphones on and the nurse told me: 'The professor was listening to the radio all night.' So indeed he kept his hearing till his last moments.

There was a restaurant near Pető's apartment where he would 'reside' at his regular table on certain days, and where people could meet him and his company. He invited me once, when I was already living alone. 'Come to the café,' he said. He introduced me to a very fine man there. I even invited him to come and see me once. His name was Imre Pán and he also was a member of The European School. He and Kassák were writing a book together. I am sure Pető had contact with him too in the fine arts - Petö was a man of extremely diverse culture, such as I have never met in anyone else in my life. He was a genius and created a world school. He deserved much more than just one book. Nobody else thought of what he did in connection to illnesses, that you could get other nerve centres to work instead of the one affected by the illness.

Something happened once, which was very characteristic of him. He was in a very good mood, especially light-hearted, you could tell something momentous had happened to him. He said: 'Today was the happiest day of my life. A 5-year-old child, who could not utter a single sound before, blew out a candle today.'

This from a man who had to fight a lot of difficulties throughout his life. He was born in Szombathely. Mindszenthy, who was a good hearted but limited boy and who later became archbishop, was his classmate. Petö, however, was not accepted to study at the university because of his ethnic background ${ }^{175}$ and because of this he had to go to Vienna. Later his colleagues would always try to dispute the validity of his degree.

As a young man, Pető was writing articles for Pester Lloyd. He should have gone to study literature, meanwhile he studied the works of German dramatists (Mária Hári has that material). I actually know more about his writing abilities, and I would like it to be publicised, because I saw the plays and poems he wrote. He showed them to me. Once when in the coffeehouse, he was reading a newspaper, but then he started to write and write. Finally he handed a poem to me which I have kept ever since.

Suspiciously beautiful woman, Ágnes

A slowly blossoming branch she becomes

When I don't see her I can see her still

When she is far she is still not far from me

1751920 Numerus Clausus 
He talked about his family only once. He took out a photograph of his very beautiful, young, blond wife: she was wearing elegant, long trousers and a dog was standing beside her.

'This is my wife,' he said.

'Professor, what a surprise that you are married.' I replied.

'Yes, . I actually hated the whole thing, but by the time I got there the flowers were all done and at the end I had to marry in church.'

Later he added: 'Look, when I came out of the ceremony I thought to myself: some people have a hunch on their backs, I have got a wife. Once she wrote a letter asking me to divorce her, because she could have married again. I am not going to divorce, because then I might marry again.'

\section{To end our interview, Mrs Imre Kenyeres said to me:}

It is also your task, and I would like you to accomplish it, to shed light in your book on his medical education, which many have tried to cast doubt upon. A wise man once said: to do something is not a great thing, but to be someone is. And this holds true for Petö, whose interests grew in many different directions. I have had conversations with outstanding people, but what I have spoken with Pető of culture, theatre and literature - and it is hard to recollect it all - was unmatched by all the others. This was not only due to his wonderfully captivating personality, but also to his whole culture.

He could make Eastern culture his own without its mysticism, though there was one mystery in it that interested him, without him ever talking about it. It was life after death.

Pető died in 1967. I heard the news on a bus where I ran into Vera Mérei. She just tossed it in front of me: 'I don't know if you heard, Pető has died.' (Sándor Márai wrote about it).

I was invited to the opening of the new building together with those who had been close to him. Maybe the statue was already there.

For the 100th anniversary of his birth a book was going to be published. Mária Hári asked me to write something and also to help in editing. Unfortunately, a lot of my writings and documents got lost and I gave several to Mária Hári. The whole endeavour was taken up by the journalist Tibor Franka, who later became editor of a right-wing newspaper. He was quite a well-known man and he was on good terms with Mária Hári as well. Among the other writers would have been Mrs Radnóti, Imre Pándy, Károly Ákos, Magda Radnót, Erzsébet Andics, Iván Mándi, Ili Székely, Hédi Gráber, Sándor Török, the Szurdi boys, Gábor and Mariann Mihályi. I don't know about Pető's connection to Kodály, though I was good friends with his wife, Emma, and she would have mentioned it to me.

For me Pető didn't die - so many memories bond me to him. For example, my grandson, János was born in the year that he died. Petö was still alive then, and he phoned me more than once asking: 'How are you, Grandmother?'

Or there is one other thing, one of Petö's methods that I use even now: I pronounce in myself the deeds I do. 'I am heating water, I am pouring it into the teapot, I am taking it out, I am bringing it in' and I count in the meanwhile, because it gives certainty to my steps. In this sense I miss him terribly, or rather: he is here with me every day. 


\section{ILONA SZÉKELY ${ }^{16}$}

It was 1948, and a group of children in state care arrived at the Institute of Special Education. My husband worked for the Institute, he was the odd-job-man there: he heated the building, took the laundry to the laundrette, re-glazed the windows, and tidied the garden and so on. We didn't have a flat; I stayed in the garden of the Institute with my baby daughter ${ }^{177}$. Petö told my husband to bring his family inside, and they would make a flat for us there. My husband carried the coal out of the cellar and made room for us there. Ildi, my daughter, was ill. At Christmas Bárczi invited us up to the schoolrooms - as all children had already left for the holidays. Bárczi said: 'Come on, girl, let's go to the first floor. For the time being you'll get a room and we'll put in an iron bed on which you can sleep. Then Bárczi drew a Christmas tree on the blackboard with coloured chalks and said: 'You should have your own Christmas tree.' He touched my daughter and realised that she had a fever. Bárczi - I have respect even for his memory - stated that it was otitis and talked to Petö (I only learnt about this later), and they got penicillin for my daughter, which was an almost non-existent treasure at that time. My daughter recovered very soon after that.

A few days later I met Petö and he told me to take my daughter out in the fresh air every day from then on. Ildi couldn't walk yet, she was only ten months old. Before that I had seen Petó every day, I always greeted him but he never said hello. But then one day Pető was walking there and I greeted him, and he stopped and asked: 'Do you have no other work than this one child?' 'No, I don't, doctor Petö' I said. 'Well then, come in to me, I'll give you work.' 'But where am I going to put my baby?' 'Bring her in' he said 'or solve it however you can.

On the firs floor there was a room, where the patients laid on wooden pallets. In the big room, where the children were accommodated, there was a cage with parrots in it, given by someone. Above it a Rákosi-picture, underneath sat Petö. These two bald heads were rather strange and made me laugh. My work was that if one of the nurses, Matild, told me that a child had to go to the loo, then I had to pick that child up and take him or her to put on the potty. This was my work from morning till evening. There was a strongly mentally disabled girl. Usually I had to take her. Once it looked like Pető was watching me when the girl was in my arms, she had a cold, her nose and everything was running. I thought 'Why should I always wipe this child's nose?' and said: 'Come on, Hetty - Heather was her name - , let's hold this hanky together!' She looked at me a little bit dully, presumably nobody had ever asked her such a thing, but I held her hand and we wiped her nose together. I praised her. Then Petö called out to me: 'Would you stop for a minute, please, you'll amount to something one day! From today on you won't carry a single child again. You will lead the children in a way that you'll stand face to face with them or they will push a chair in front of them. And teach them to wipe their noses.'

Well, from then onwards we could only help them in dressing and showing them how to do things. They had to work with us. Which meant that not instead of them and not with them, but leading them, working together. I had no idea then that this was a method.

In the beginning there were limp, paralysed and spastic patients, those with Parkinson's Disease, men and women all mixed together. Adults were not separated according to their sex during the sessions.'

\footnotetext{
${ }^{176}$ The first conductor, right hand of Petö

${ }^{177}$ Mrs. Kozma, Ildikó Székely was one of a director of the International Pető Institute
} 
We saw numerous patients who, as a result of the treatment, were able to change position independently and move their upper limbs - at least to the extend of satisfying practical demands, and some of them achieved complete rehabilitation.

In tiny little steps, Pető started to develop his therapy enhancing educational method for patients suffering from this special motor disorder: conductive education. In the beginning he worked with all types of illness.

He was a magnificent and excellent man. Only those got to know him who were able to understand his very complex personality. For Petô everybody was the same, he didn't differentiate between people whether they were/had a coruscating personality or talented or not. One had to love him very much in order to understand him. A lot of people didn't know this, and even more did not understand him, therefore they didn't like him, he even had many enemies, but still there were many admirers of him, those who had understood him.

He helped a lot of people, not only with his knowledge but he also financially supported those in need. A book had to be kept about how much money he should give to people. He didn't even know how much his salary was. He was paid from different places and then he just stuffed it into his pocket. I know of at least two occasions when we left his salary behind in taxis. In taxis he was always talking about tasks or he would be busy with something else and put the money next to him or he pulled a handkerchief out of his pocket and then he also pulled his money out with it. But cases like this did not trouble him.

There was no such thing as fixed working hours, we worked from morning till evening, especially those who lived in the Institute. My daughter slept on a pallet, and I also slept in the same bunk-bed when I was pregnant with my younger daughter Judit.

The Institute opened in February 1950 - as Petö had planned. That was the time of the Heine-Medin epidemic. Győző Ferencz rang Pető from the László (infectious diseases) Hospital to tell him that the hospital was full of cases from the Heine-Medin epidemic, and that those who were safely over the acute stage should be taken away in order to make space for new patients. He wanted Pető to take them in at his Institute and rehabilitate them there. After the 'nose-wiping' episode Pető taught me regularly and even gave me special lessons. He sent me out to the László Hospital, to the pavilion where the iron lung patients were.

There were six of them altogether. A doctor led me into the room - dressed in protective clothing, naturally! My task was simply to observe: I was not to breathe a word or move a muscle, just be very attentive and if I saw the initial signs of one of them starting to breathe unaided to point them out. Pál László and Pál Hideg worked in our Institute after their recoveries. I agreed with Dr Ferencz that they would start transferring the patients to our Institute. First they had to put the paralysed patients, who were unable to breath, into an oxygen tent, and then into the fresh air for a minute or two so that they could practice the necessary motor functions. They would only contact us when the patients were able to breath with their own lungs, without the help of a respirator, whilst asleep. That is how Heine-Medin patients were transferred to the Villányi út Institute. There were also other Heine-Medin patients but they were not respirator patients. There were two rooms at the Villányi út Institute for patients from the hospital, and we accepted some others, who were severely spastic, at the urging of Focher, who was the Director of a home for destitute children.'

Many a time he held so called open sessions. During them he gave the new tasks to the group, but the way in which we helped, 'facilitated' had to be made up by us. We had to help as if we were not actually helping. This is hard to understand, but it is what conductive education is: leading, directing. The solitary violinist needs no conductor; the sheets of music and his own soul direct the making of music. This is what conduction is. 
Pető worked on the form, content and duration of the training intensively. What we were called changed many times: we were movement therapists, child nurses, but none of the names covered what we were actually doing. He was looking for a special training and a name that would easily be told apart from everything and everyone else. Because the world could hardly understand what we were doing, they could not really put it into words either. Foreigners were already showing interest and we still didn't have an acceptable name. The method continuously changed. The phrase 'to correct' or 'rehabilitate' caused Petô enormous problems, because he didn't want people to think of us as physiotherapists, which would have put the independence of the Institute into doubt.

Then 'healing education' was thought of, but he discarded that as well. In essence, the conductor is a professionally trained mother, who directs or conducts the activity of her child. In this process everything we do is included. Because it is the mother who teaches the child to sit, walk, talk and live.

In Peto''s method, it is the conductor who takes on this role.

He believed in Eastern culture's truth deeply. I also had to study it although I couldn't really understand it. There was Buddhism in it and lots of other things from Eastern religion. He believed in a lot of things, he explained the importance of the phoenix ${ }^{178}$ to me, he talked about that a lot. He believed in reincarnation. Many people have misunderstood Mária Hári's devotion to doctor Petö, but he always said: 'Listen, Marika, try to understand that if I cease to exist then I will enter into someone as a phoenix, may be into you, Marika.'

This has remained prominent in my memory, because I found it very interesting.

He had a worn, grey coat on, on the last day when we took him in to the Institute: he was already past recovery then, but he wanted to go to the Institute. I went to his flat to give a report and then he said: 'Ring the garage caretaker to send me a car.' The garage caretaker probably dropped the receiver in amazement: 'Comrade Pető is going out?' 'Yes,' I said 'he is going in to the Institute!'

When we got in, Petö's lips were already grey. He asked me to ring half the city: everybody who counted in the health authorities. He even me asked to ring László Pesta, who at the time worked in the House of Parliament in a very high position, all rehabilitation matters including the social rehabilitation of recovered patients were under his auspices. Pesta promised that he was going to intercede in Parliament about reserving certain jobs for those adults who recovered at the Institute and are able to work. There is a list of the people who got work there, and some of them still work there today.

So, when we got to the Institute he summoned together people in high position. An exchange of views took place between them about how legally to protect those who recovered from their conditions, so that they would still be able to work.

This meeting went on from nine in the morning till the afternoon (In the meantime he asked me to bring coffee. I didn't dare to tell him in front of the guests that we didn't have cups, and for people of such high standing we couldn't give the mugs out of which the children in the Institute drank. I started thinking how to solve the problem. I ran hastily to the financial director and told him that we didn't have any coffee cups, just plastic mugs with two handles, we also used those, just like the children, but we couldn't serve coffee in them. Finally I poured coffee into big water glasses, which had been bought for the children, and I put them on a big tray and, balancing it, I took it in and put it on the table).

\footnotetext{
${ }^{178}$ Phoenix: An Egyptian and later Greek and Roman mythological bird, which arises renewed from the ashes of its own cremation.
} 
Suddenly Pető shouted at the receptionist: 'Ilike, Marika!' The receptionist had to work out from this that he wanted to see us, but he hadn't said so in so many words, just: 'Ilike, Marika!' I had run to fetch Marika and then we went in. I stopped in the doorway and looked at him: he looked very unwell. 'Well, I have sorted that out' he said. 'Do not forget this. Mr Pesta is going to intercede. He is an honest man, but he may not be able to keep his promise.'

Everything and everybody had to be checked, even himself, so that nothing would be forgotten. He had reason to check everything but he was even stricter with himself. There were still two glasses of coffee on the tray. Petö knew that I adored coffee and he also knew that I smoked. Nobody was allowed to smoke except me. The two of us sat there and drank our coffees. Suddenly he looked at me, stood up from his chair and came over to me, his skin had a strange colour, and he said: 'Oh, Ili, I'm going to die.' He sank into the armchair, falling forward. I put his medicine under his tongue but in vain. It was too late. 


\section{PROFESSOR PÁL GEGESI KISS ${ }^{19}$}

We have to start the Petö-problem from further back so that events will be clear for you. Congenital lesions with motor disorders is one of the very sad and serious problems of infant and child-care. These are partly due to birth injuries and partly to damage during pre-natal life, they have much less to do with hereditary problems. These are very serious difficulties: the children are unable to move, and because of this they are also affected mentally as well, from early infancy on. I am one of those paediatricians, as is clear from my books, who think that the body and the spirit function together in a very close unity. We use the expressions for psychological and somatic conditions together and their development and interaction can only be pictured inseparably.

I have worked at the Children's Clinic of Budapest since 1924. I trained there, and have been in turn a clinician, an assistant lecturer, a private teacher and, finally, a professor. I was appointed as a teacher at the clinic in 1946, but it was mostly during my time as an assistant lecturer, in the mid-thirties, when I was already a private teacher, that I had serious problems with behaviourally disturbed children who had motor disorders as well as being mentally affected. I believed some of these cases could be solved by other than the classical methods of child-care such as through surgery or medication. So whilst still a clinician in the mid-thirties, I created a kind of clinic or treatment, which after careful consideration received the name: Educational Consultation - avoiding the term 'psychological' because of the parents. At this point nobody had heard of Petö, it was Lucy Liebermann, a very fine woman, who became my colleague here in the clinic. Her husband was Pál Pátzay, the famous sculptor. Lucy took on the task of directing this Educational Consultation.

I didn't develop this consultation as an independent section of the clinic, but as part of the paediatric department. I gave them a separate room where the day-care patients were received and it worked well. It worked so well, in fact, that later in 1965 Liebermann and I wrote a book about its development and effect.

When after the liberation I was appointed professor and director of the clinic, these consultation hours became more and more intensive. It was during these times that Petö came into contact with me, as with the director of the institute. He told me his concept and I agreed with it completely. The essence of his method lay in the effect of bodily exercise on mental functioning and vice versa, as put into practice with young infants and children in order for their condition to improve. Petö never wrote this down, but this is what he was doing and he described it to me.

I answered: 'My dear colleague, I have five lectures every week, and I 'd like to give you one, so you would start to teach the fifth year students, and all this could become an integral part of their body of knowledge in child care.'

This was sometime after 1946, but I cannot recall when exactly. I didn't consider Pető an immediate colleague like Liebermann, who was receiving patients. In the clinic Petö only gave lectures for the medical students, and he began to organise his own institute. He taught the conductors how to work with the children through emotions, and how through emotions you could reach them intellectually, and develop their movement at the same time. These sessions were filmed later on.

\footnotetext{
${ }^{179}$ Pál Gegesi Kiss (1900-1994). Pediatrician, university lecturer and academic. Holder of the Kossuth Prize, founder and vice-chancellor of the Medical University of Budapest. His scientific work was of exceptional importance.
} 
Then our connection broke, he didn't need a classroom at the children's clinic anymore, he had his own institute. He slowly gained international fame and didn't need to give lectures.

To sum it all up, this was the essence of it. These were very hard times for him. You cannot imagine how much it meant to him that a professor accepted his ideas and said: 'Here, I give you an opportunity to teach this to the students, because I think this, your method, is an essential part of child care.' This was a spiritual protection to a man like Petö, of whom nobody as yet knew anything.

\section{What was he like as a man?}

I cannot tell you much about that. I do not know his personal life at all.

\section{How much was he appreciated professionally?}

Initially he wasn't appreciated, but he became well known through his lectures, since the number of fifth year medical students was several hundred. He didn't only give a lecture once or twice, but he was given a lecture regularly out of the five I had. After his lecture series everyone had to know how to handle a motor disabled, mentally affected patient and how these patients were worth handling. The essence of it was to win the child emotionally in showing love towards him or her. Well, those conductors won the children.

A new-born baby can already sense, when nursing at their mother's breast, that they are in contact with something that satisfies their feeling of need.

Is Pavlov's reflexology a professionally sound or a political part of the Petö-method? In the socialist camp after the Second World War it was almost a must to build onto the results of Soviet science.

Let's start with the part of psychology that was begun by Freud. Already that was received with much resistance and disdain. They didn't accept Pavlov's or Sechenov's statements either. I on the other hand, as a scientist and academic, I accepted Pavlov's results. Petö turned to me exactly because he agreed with them too. This was before any of my books were published, but in my articles and lectures on healing, the concept was clear to see. I had a reputation and influence among doctors and artists and I had a spiritual influence on people. (For example my poems were published in Kassák's literary magazine $M a$ (Today).

I found it was natural that Pető turned to me. Not only because I had authority, but also because I agreed with the concept and its practical application in cases of motor disorders, where previously only orthopaedic solutions were used. These cases they tried to solve through working with the children's personalities by psychological means. If you go into that institute now, you will see the conductor doing all she can to win the children through mutual work and love, and that in return the child is making a big effort to please the conductor. This mechanism is able to get rid of a disposition called inactive atrophy, which is not a physical deformation, it consequently remodels the whole personality. This is the essence of his technique. Because you do need a technique to know how to move a few-months-old infant, or one that is already learning to walk, or one who is completely paralysed.

In your opinion, Professor, did the Heine-Medin disease of the time influence Peto" in the founding of the Institute?

The Heine-Medin disease is a deformation of the movement system that is different from that which Petö took as a starting point. The children affected could not move either, however, so what was left of their capabilities Petô tried to strengthen. 
Later Pető's activity and ideas became clearer and more pronounced, and he built up the needed personal connections beyond my influence. I think my influence had a spiritual nature. Through these concepts I made it possible for him to present his method in front of a big audience, and more importantly: in an official, scientific and academic forum.

This was his only lifeline in medical circles.

Not a lifeline, but a support. He was a strong spirited individual. I had no part in the preparation of his Institute, or in his becoming world famous. I only had a part in that I accepted his ideas, I felt they could be harmonised with mine, and I gave him an opportunity to voice it within the public system, presenting it as something accepted.

Later we didn't keep in contact at all. Today his method is being taught world-wide. But my role was only to give him a spiritual possibility, he could lean on me and say in the '50s: 'Professor Gegesi agrees with this and stands behind it.'

That counted for a lot at the time, since people were trying to hinder him from many places; they didn't accept him professionally. This is why it was important that you stood behind him. Professor, in what position were you then at the Medical University of Budapest?

In 1949 I was the last dean ${ }^{180}$. After the political reforms it was I who organised the whole university, so this was thought to be an important, influential position. I was Vice Chancellor till 1961, I organised the three faculties. The Minister was Anna Ratkó then, and she said to me:

'Comrade Gegesi, this is a question of pride with you. It is unnecessary to build up a whole university, they will do fine as faculties.' But it turned out that I was right. I treated her 5-yearold daughter, she was my patient, they trusted in me. Despite all of this, Ratkó didn't support me in my plan. I told you all this so you could understand what sort of weight my name gave to Petö, when it was I giving him a chance to appear.

We were not friends, this was a spiritual connection. At the time I was Vice Chancellor, an official teacher at the university, I had fulfilled my spiritual potential, and I gave an opportunity for his spiritual manifestation. Through his lectures he could build himself into the science I was leading. This is what our relationship was about.

\section{This was quite an important thing for him then.}

To be sure. It is quite a big thing even today if somebody accepts a new thought. The infants and the young children had hopeless pathographies. They were not like the HeineMedin infantile paralysis epidemic, where a definite virus infection appeared spontaneously, here the serious motor disorders were congenital and could also lead to mental disturbances.

The tenth chapter of my book (Basic Psychology, 1966) deals with illnesses and symptoms and with cases where the illness appears in the physical body as a result of the psychological components which define the personality. Consider this sentence: 'Everything has an effect on everything,' which sums up the whole concept. The psyche, the soma, is the union of all, and as one component affects the other and creates that which we call personality itself, it also defines the psyche.

\footnotetext{
${ }^{180}$ Péter Pázmány University, like all traditional universities had not only a medical faculty. Professor Pál Gegesi Kiss was dean of this faculty until 1949. After reorganising and renaming it, a new university, the Medical University of Budapest was born, where he was Vice Chancellor until 1961, with three faculties: General Medical, Dental and Pharmaceutical.
} 
Then there is a much more difficult book than that, the Psychopathology of the Children's Clinic (1971), which Lucy Liebermann and I wrote together. In this book the statistics, the analysis and their proofing are very interesting. Disturbances of behaviour, when somebody is a danger to society, anti-social, or without society, asocial - which is very common today is a problem just as important as motor disorders, or maybe even more so.

My whole concept is based on the problem that education towards becoming humans is not being solved. Just to give one example: In partnerships how can one control oneself and one's partner through one's consciousness, preventing a divorce after two years (possibly with an infant already or with two children). For example, I have just recently read that the number of girls under 15 having abortions has increased. This means they must have sex at 14, in order to have an abortion at 15. Is this a normal thing? No matter how many hormones are at work, what does a 14 or a 13 -and-a-half-year-old girl really know?

The world was a really difficult place in the beginning of my career. We lived in historical times in 1920. Seven of us sat in a cattle-truck and came over to Hungary from Romania, because the Peace Treaty of Trianon ${ }^{181}$ declared that the Romanians could take over the area I lived in. I fled to Orosháza, where I worked for 10 years in a voluntary position.

\section{What did you live on?}

Whatever we could cadge. Then things got better. Now my wish is that education would become an independent section of science, done consciously and methodically. First parents should be educated, in other words: they should be taught how to be parents before they become them. Then the teachers should also be trained, so that teaching would become education. What is needed to bring up human beings is education. If learning stops at the level of getting knowledge, then it is egotistical. We need knowledge so that we can live in society, choosing between the ever-present prohibitions and possibilities, and so that we can live in such a way as to make life worth living. I went to see Dr Miklós Kun ${ }^{182}$ as well.

Really? Well, he is completely different type than me.

He told me that he worked together with Flora ${ }^{183}$ in Szondi's ${ }^{184}$ laboratory, and that he was in Petö's circle of friends.

Well, yes. Szondi was a concept in himself and so was his school. I wouldn't say it agreed with my school or spiritual concept, they went in a different direction. Actually my resistance got its start from finding it hard to accept into my classical clinical psychology that we were dealing with disturbances of personality and not of the psyche. I explain this resistance in almost all of my books.

Pető showed that it was worth working with the problem — and it is an important problem, because clinically we are totally incapable in the case of these patients: we can only treat their symptoms - and that it is worth building up an institute where you can prepare another system

\footnotetext{
${ }^{181}$ The Peace Treaty of Trianon, signed in Paris in 1920, set the territorial and financial conditions pertaining to Hungary, as well as codifying the demise of the Austro-Hungarian empire. Considerable Hungarian and other territories were removed from Hungarian rule.

${ }^{182}$ Dr Miklós Kun psychiatrist, director of the National Institute of Psychiatry, one of the leaders of the International Red Cross and of Joint in Hungary.

${ }^{183}$ Mrs. Illés, Flóra Kozmucza, a doctor and Attila József's lover

${ }^{184}$ Lipót Szondi(1893-1986) Neurologist, psychiatrist, he lead the Physiological and Pathological Section of the College for Special Education. In 1943 because his ethnic background he fled to Switzerland and then to America. He founded a new school of depth psychology called 'faith analysis.' His tests for instinctive diagnosis are used in psychiatry and neurology.
} 
and put it into practice. He showed that you can get students and, as we have seen, you can also become world famous. Because I think that that is what he is.

Of course he needed help to found his Institute and to actually run it. Economically, politically and spiritually, as I supported him spiritually and gave him a chance.

Politically he was leaning onto Ortutay ${ }^{185}$ and then onto Biszku ${ }^{186}$.

Gyula Ortutay was among my good friends, I had a spiritual connection with him. He was Minister of Culture and Education, then later an academic, and Biszku had great power in the Communist Party.

You needed fanaticism for the extremely hard work Pető was doing. Well, I am quite aggressive myself, as you may have heard. He was belligerent in his own field, too.

Well, that's all I can tell you about Petö.

185 Gyula Ortutay(1910-1978) ethnographer, politician, Vice Chancellor of the University of Budapest, academic. 1947-1960: Minister of Religion and Public Education, 1958-1978: member of the Presidential Council.

${ }^{186}$ Béla Biszku(1921-2016) 1957-61: Minister of Home Affairs, 1961-62 vice President of the Cabinet. 



\section{PROFESSOR PETER POPPER}

Would you please tell me about your first meeting with Petö, and talk about the development of your relationship with him and about him as a person.

I should be honest, shouldn't I?

\section{If you can be.}

Of course. Well, the psychiatrist Miklós Kun, whom you also know, belonged to the circle of my mother's friends. And he somehow introduced her to Petö, since my mother was always interested in eccentric people and was possibly one of the last people in Budapest who had a salon, a Parisian salon, where chamber concerts were held. There were always a lot of interesting people gathered there: actors and actresses, writers, painters, aesthetes and other eccentric people. My mother pursued these interesting, great people; probably for mainly subjective reasons. She was the daughter of a poor Jewish priest, who had many other children, so she couldn't have a proper education, as she had to leave the grammar school when she was 16; she couldn't do her final exams and that hurt her a lot. This salon was, I think a kind of compensation. Later she told me all kinds of admiring tales about Petö, which made me curious. At that time I was 19, in my first year at university.

Was it possible to have such a salon of friends at that time (at the height of communism)?

Of course. Why shouldn't it have worked? Just as I invite to my house whomever I want, don't I? People were invited there, such as György Kósa and his circle of friends, Ági Molnár, Endre Kemény and Árpád Mezei. Imre Pán hadn’t emigrated before if I remember correctly, he was an aesthete. Well, I don't know it anymore, a lot of people. Miklós Kun among them, of course. Sándor Török, Eszter Tóth, I think. Earlier the Góth couple - they’re dead long ago, or the actress Ella Kertész, Sándor Guth and other personalities like them. And then I started begging both my mother and Miklós Kun to introduce me to Petö. Petö didn't go there. He wasn't the kind who goes out anywhere. Now I don't remember any more who arranged for me to meet him. If my memory doesn't deceive me, it was Miklós Kun. He arranged an invitation for me from Pető. One Thursday evening I had to go to Pető for dinner, who had already heard about me. Look, by then Petö had become a living legend for me. Now, I'm adding to the legend, I don't deny it. In the end I don't really know. Anyway, on the whole things happened as follows, I might have polished them a little bit, in order to make the story better, but it happened more or less like that. I take responsibility for it. Anyhow all that happened is quite delicate.

I went to see Pető in Béla Stollár Street where he lived in a flat at the Bródys on the fifth or fourth floor of a house, I think it was on the fifth floor. Would you please remind me to explain things if they're not understandable?

\section{Did the Bródy family not live there any more?}

I don't think the Bródys lived there by then, the flat was almost completely empty, but Petö still lived in the servant's quarters which had a separate entry from the staircase. So one could go into his room not through the main entrance of the flat but from the stairwell as well. It was a summer's day, it was hot, but still they had the heating on which gave me a surprise. Petö was susceptible to cold and sometimes he asked for a fire. Why he was so susceptible to cold, I don't know. I lived in India for a while and there I was told that those people who are seers,

\footnotetext{
${ }^{187}$ Professor Péter Popper (1933-2010) psychologist,
} 
they're called geodots, become very susceptible to cold. I don't know whether this was the reason for him to be so sensitive to cold. Anyway it was hot and as far as I remember it was quite stuffy.

Look now, I'll tell you everything that happened, and later we agree what you publish out of this. I don't mind if everything comes to light, but then it's up to your good conscience. But to get back to the story, Petö was sitting behind his desk and dining. There were masses of books everywhere in the room and magazines on the floor in piles. There was also a delicate coffee table with crockery and cutlery laid for two and I was seated there. I'll tell you how it was. A strange woman sat down next to me. Mária Hári, who later won a national award. There was a housekeeper called Mariska, she showed me in. I greeted Doctor Pető and introduced myself. I don't know how he reacted, because I was so overwhelmed by his appearance, he looked like Buddha. I don't know what that means to you but he was fat, bald, and his face was Buddha-like, and in between his legs there was a hydrocele the size of a watermelon, and because of this his gait was very strange. He had one row of teeth, of which he was very proud. Where he had teeth on the top, he didn't have any on the bottom and where he did have teeth on the bottom, he didn't have any on the top and when he shut his mouth you could see only one row. He guffawed about this. Everybody called him the chief physician; as Luther was called 'The Doctor' so Petô was called 'The chief physician'.

We started dinner. Mária Hári and myself sat at the coffee table and the 'chief physician' at his desk, opposite us. Mariska brought the food in. There was a big dinner for the times, soup, and then fish with some garnish. I was immediately shocked by the unique way in which Petö ate fish. He cut big pieces with a knife, put them in his mouth and he spat the bones out, like phü, phü, phü. It fascinated me and I was occupied with watching him eating fish. But he didn't say a word. We didn't speak either. There was silence. This wasn't unusual with him. Sometimes he talked an awful lot, till late at night or till the first blush of dawn and other times he didn't say a single word. It was evening. We were eating. Then pasta was served and after supper there was jam for dessert in water glasses for each of us. The chief physician liked it very much. We ate that as well. As I later discovered it is healthy, it's good for the heart. Afterwards coffee was served. Again in water glasses and it was extremely strong. So we had a big supper. But in Petö's life it wasn't always like that. Sometimes he ate only once a day, often he got excited about saveloys as they were the most easily digestible meat one could get. So his eating habits varied. But that night there was a big dinner and nothing happened for a long time, we ate without saying a word, I, as a 19 year old young man, hardly dared to breathe. Later the doctoress stood up and left.

Just the two of us stayed. At that moment I already knew that I was in the presence of a lunatic, but he was an extremely fascinating lunatic for me. Later though my opinion of him changed. But then and there that's what I thought. The two of us finished dinner and then we were silent. He was silent so I didn't dare to talk either. And after an unbelievably long silence he said a sentence with his unique emphasis, something like. 'Spinoza was already a taciturn man at the age of 40.' I acknowledged this, it wasn't too strange to me, as I was studying philosophy at university as well as two other subjects, and although I hadn't learnt that Spinoza was a reticent man, I didn't contradict Petö. And we sat in silence again. He sat watching or even staring at me and I found that very disturbing. I felt as if he were pushing me, I had a feeling that he goaded me on, there was some sort of pressure radiating out of him towards me. There was even a direction of this goading, towards one end of the room. Naturally I resisted and then he suddenly said 'Why put everything into words? There is the chest of drawers, in it my bedding, would you make the bed for me!' By then I was ready for anything, so I started doing it. There really was a sort of chest of drawers or maybe it's called a commode, I'm not 
an expert on furniture, there was bedding in it, which I took out. There was a sofa. I made the bed, full of trepidation. To put it frankly, I didn't understand the situation. When I finished it — in the meantime Petö watched what I was doing — suddenly everything turned out wonderfully, because he said the following:'Thank you, my boy, it hasn't happened for 23 years that someone made a bed for me with love. Now you go home and I'll see you again next Thursday.' This was the first meeting. You asked me about it! And then I went home, quite touched by the end of the evening but I was also quite shaken. I now have a different feeling about that evening, whether he meant it seriously or not and why 23 years, but anyhow at the end he won my heart, that it was me who made his bed with love after 23 years.

\section{And did you really make his bed with love?}

Look, I think this is an exaggeration, because love is a very strong word, but by all means I made his bed kind-heartedly, because there was some sort of great solitude radiating out of the man, which I had felt. I felt, that he must have lived in some kind of great spiritual solitude, and at that time I couldn't see through his life's complete network, because I didn't understand a lot of things.

\section{And later?}

Look, from this point on everything divides into two. On the one hand there are the Petö stories. On the other hand one of Petö's colleagues told me that Petö is an apostle and a scoundrel in one person. It is not true at all that he was a scoundrel, and neither was he an apostle but that was closer to the truth. I personally think that Petö lived beyond social conventions, to the disgust of a lot of people, and that roused indignation in a lot of people. Now here we should not only think about how he led an unconventional life - I could tell you endless stories about it, but then we would be sitting here until dawn. So, partly he ignored conventions, and partly he just loved taking the Mickey out of people, making a fool of them, and generally confronting them. I don't know if Gábor Palotás will also tell you some of these stories, as we have many common tales. From the story I told you about spitting out the fishbones you will already have gathered that he didn't make a secret of his biological functions. Palotás will tell you the story, if you ask him, of what happened when Mr Szijártó, the Minister of Building and Construction, visited the Movement Therapy Institute. The story is a very typical one.

Pető fought a life and death struggle with his great enemy, Gyula Hatos who was an assistant under-secretary at the Ministry of Health. Once, for example, Petô was giving a presentation in front of the children when Hatos suddenly interrupted the presentation. Petö thought nothing of standing up, going over to the children with his peculiar waddling gait, and saying to them: 'Now, children, the chief physician will teach you something. There are two kinds of ass in the world, one who knows exactly that he is an ass, and keeps quiet, and the other who doesn't know and therefore interrupts someone else's presentation.'

Well, Hatos was Petö's boss in the Ministry, but in the end it was he who resigned!

Another example of Petö's disrespect for conventionality was when the Professor of Anatomy, Ferenc Kiss visited. The mere fact of his visit was extraordinary, since the official medical establishment really hated Pető.

\section{Why did they hate him?}

Partly because he was an unconventional person. I only realised this later, since I didn't understand it at the time, I only saw that there was an unbelievable hatred around such people 
simply because of their unconventionality. I think the root cause of this hatred is that people envy the inner freedom of such people who dare to live beyond convention.

On one occasion I introduced Petö and my boss to each other, as the two most important people in my life, and on another occasion three people: Ms Lucy Leibermann, Sándor Weörös and Petö, all three of them were unconventional people. Not long ago I wrote an obituary for Ms. Liebermann on the 20th anniversary of her death, under the title 'The solitude of the unconventional psychologist.' I think that that is characteristic of Petö as well and secretly I think the same about myself.

Anyway, envy of that inner freedom arouses hatred, but this is crystallised into a more concrete form and the easiest thing to say about Petö was that he was not a Doctor, but just a charlatan. This happened very frequently.

When he worked at the College of Special Education he was constantly being asked to resign, but there were a few people who protected him. He always told allegories. Palotás and Szijártó know how the Movement Therapy Institute was established in Csalogány Street. There is a very interesting story about a woman who travelled to Switzerland and later went there for advice.

So, there was the original building of the College of Special Education, and Petö started there. Or for example there were Petö's love affairs, which were just as unconventional. I don't know if anybody dared to talk to you about them?

Well, Miklós Kun told me that Petö's lover was always one of the woman Doctors who was on duty with him.

Yes, that's true, but there were tragic love stories as well. You see suddenly lots of stories about Petö are thronging up in me. But to return to his unconventionality, he was indiscreet. Yes, I wanted to tell you about Ferenc Kiss' visit. The Professor of Anatomy came to visit - we could say that the official medical establishment came to visit Petö. And I can assure you, that there were very few Doctors who were in agreement with Petö. Once a Professor of Paediatrics, Géza Petényi, visited him, and that was an enormous compliment for Pető. And once the 92 year old Pál Gegesi Kiss, who is disparaged nowadays but at the time was giving lessons to Pető about paediatrics, invited Petö to give a lecture at the University of Medicine. He was the Vice-chancellor at the time, and this was an event of tremendous significance, since it would have meant Petö's acceptance into the medical establishment, if only the following incident had not occurred.

A crowd of people were gathered in the lecture theatre at the paediatrics clinic. It was packed, because the news that Petö - the peculiar - was to lecture had spread like wildfire. And then he arrived, went up onto the podium to start his lecture, looked around, and noticed one particular Doctor. I can tell you his name, it was Fényes, a neurologist. Petö shouted out in a stentorian voice: 'As long as that scoundrel is in the room, I will not say a word!' And he didn't. It was a scandal. His first lecture ended up in a scandal.

Anyhow, once the Professor of Anatomy, Ferenc Kiss, came and to look at the Institute full of good intentions. He was just about to leave the building, standing just outside the door with his minions behind him as usual, when suddenly Pető said, 'Kiss!' Ferenc Kiss stopped and turned round. 'Bless this building!' said Petö. Now everyone knows that at the time the Communist Party proscribed the practice of religion. Kiss, who was the head of the Free Church, blushed as red as a beetroot. He hesitated. Petö shouted at him 'Aren't you the head of the Free Church?' 'Yes sir, I am' said Kiss. He blessed the building and left. The whole situation was very awkward and when Pető was asked why he did it, he roared with laughter and said that the head of the Free Church should not be embarrassed by his position. 
When did this incident take place?

At the end of the fifties or the beginning of the sixties. There was also a catholic priest - I don't know his name - who used to come and visit Pető regularly and they had very good discussions together. He was always available, at any time, if one wanted to talk to him. Once the priest suddenly started complaining to Pető 'Oh, Doctor Pető, we live in such difficult times, you know, who knows what tomorrow will bring, what will become of the Church' and so on.

Then Petö jumped up and chased him out. 'Get out!' he said. 'What has a catholic priest got to do with the future? Do you not pray ten times a day for God to give us our daily bread? And yet you're worried about the future? What kind of a priest are you?' and he chased him out. This was very honest of Petö: he was completely infuriated, and he dared to risk a scandal. He didn't contain his rage and fume inwardly, and neither did he strain it into some semblance of manners. I think he actually really liked scandals - he used to laugh about them in an impish way. There was another story when in 1960 or '62 a Russian delegation came to visit the Institute. I speak Russian, and so I was asked to interpret. The delegation took their places opposite Pető. They were very interested, but very formal. I immediately saw an impish spark in Pető's eyes and realised that he was preparing some sort of trick. He started speaking: 'The importance of the Conductive Education Therapy which I have developed can only be compared with the importance of the Great October Socialist Revolution. Translate that, Popper!' I translated it. They sat as if they had been turned to stone. Then they thrust out their chests, and became even more rigid and formal, and Petö guffawed. Those were the sort of games he liked to play, but behind them was always his true self. You had to listen to him, there was a spiritual essence in him.

During one period Petö went regularly to the Downtown Cafe and to Elyse, and I accompanied him as a kind of Pető retinue. A few times, when I was whispering the secrets of my life into his ears, he loudly shouted across the Cafe - 'Waiter, bring Popper a glass of brandy, he's got sexual problems!' Naturally, I became the cynosure of all eyes, which was awfully awkward, but I had to be ready for this sort of thing. I'm talking about his tactlessness, you understand.

Tamás Kolos once had a famous exam with Pető. Since then he has become one of the most famous psychologists in the Heim Pál Children's Hospital in Budapest. This is a stupid story, but I'll tell you. Tamás Kolos worked in the Child Protection Department at the Police as a young psychologist, he worked with criminology. Petö, who liked embarrassing people, knew this. The university exam started like this: 'Policeman, policeman come out. First the policeman is going to answer.' Kolos can tell you this story more spicily. Anyway, Kolos went out. Petö asked him: 'What are you standing in?' Well, this is a strange question and Kolos was already incredibly upset about the policeman thing, and he answered in a fury: 'In shoes!' The professor using his favourite word asked: 'you ass, what are you standing in?' 'In socks' answered Kolos. 'You ass' repeated Petö 'you are in muscle tone, you ass!' well, these are little games.

But still... This thing of being beyond conventions. For example I think it was Doctor Balogh who renovated his flat over a period which lasted for two years. He stored his bedroom furniture in an empty room in the Bródy flat. Doctor Balogh asked Petö if he could put his furniture in the Bródy flat in one of the rooms that Petô didn't use. 'Certainly' said Doctor Pető, 'why not?' The two years passed and Balogh came to fetch his furniture. But he could not take his furniture because it wasn't there any more, Pető had given it away as a present. Doctor Balogh almost fainted, because he had spent all of his money on the renovation but now he didn't have any furniture either. In the end Doctor Petô shouted and they could not come to agreement. Doctor Balogh kept saying over and over again: 'It was my furniture.' 'But you 
should understand' said Doctor Petö 'one of the nurses, Erzsi got married and they didn't have any furniture. Well, then I told her to take it. It had been rotting here for two years by then. Why shouldn't she have taken it? Nobody needed it!' It was a deadlock. Doctor Pető didn't have any sense and understanding about private belongings and he really gave it away. He didn't care much about such things.

And then there were some mysterious stories, I'll tell two of them. But I warn you, I'm afraid that there are only a very few people who talk honestly about Doctor Petö. Usually they rather try to...

\section{To glorify him?}

Exactly. That is what was so fantastic about him. When I was 19, following the family traditions, I had psychoanalysis with Imre Hermann, with the doyen of psychologists. I had already been going to him for 9 months when somehow András Pető's name came up in our discussion. You should to know that I had psychoanalysis at that time because I got married the day after leaving school. I did it in order to annoy my parents, and the girl, who was the same age, had her exams at the same time and she wanted to upset her parents as well. Anyway, it suddenly grew into a very muddled marriage, which wore me down and among other things this was one of my great worries. And then on one occasion I mentioned Petö's name. Then Mr Hermann turned his attention to this and he realised that I regularly went to Petö. And then he said something about which we argued even when he was 90, but which swept us apart from each other for the rest of our lives. He told me, a 19 year old boy: 'Look, you've got to choose now.'

\section{In what?}

I asked exactly the same. He answered, 'You can go to Pető or to me for analysis. But you can't go to two places for psychotherapy.' 'But I don't go to Pető for psychotherapy. He's just an interesting person and I visit him from time to time, and then he feeds me and we have discussions or sometimes we are just silent.' 'No, it isn't like that' he said, 'he is such a powerful personality, that one must be under his influence and that is equivalent to psychotherapy. And one can't have psychotherapy in two places at the same time.' I didn't accept that. 'Do I have to choose?' I asked. 'Yes,' he replied. I stood up from the couch and left Hermann, which caused me problems later in my life. When I next met Pető I told him that Hermann threw me out of his analysis. He was overwhelmed, I made his evening for him with the news. His first question was whether I had always paid Hermann on time or not. 'Because you know,' he said, 'these analysts are very fussy people.' Then I said 'Doctor Petö, I paid on time, but now that this has happened, this conversation...' He was overjoyed. 'Look, my boy' he said 'you were kicked out because of me, so I've got to set things to rights. But why exactly did you go to psychoanalysis? Because you know, I know everything that these analysts know, I just work a bit quicker - you'll see.'

And then I told him that I had a failed, bad marriage, full of suffering and jealousy. Doctor Pető listened to me, I noticed that he had heard enough. He asked me where my wife was at that moment. I said that she was on holiday at Lake Balaton. 'Without you?' he asked meaningfully. I said, 'Yes, because she already broke up for the summer holidays'. He called for a man who used to be an in-patient at the Institute but who had by then been rehabilitated and employed there. 'Pali, Pali, Pali' he turned up. 'Pali, bring a pen and paper for Popper, and here is twenty forints, take a taxi and bring ten fishhooks from the fishing shop.' then he turned to me. 'Now write this down, my boy: My dear wife, Zsuzsanna!' I told him that my wife's name was Zsuzsa, not Zsuzsanna. 'Don't worry, just write Zsuzsanna.' So I wrote it like this: 'My dear wife Zsuzsanna, I've heard that you are having a wonderful time at Lake Balaton,' he 
dictated, and went on: 'and you've become a fisherwoman. Enjoy yourself for the rest of your holiday, I enclose some fishhooks! Greetings from your ex-husband, Peter.'

I was utterly shocked, but I couldn't do anything. Petö dictated it to me and I had to write it. Pali came back with the fishhooks, we put them in the envelope, sealed it and I posted it.

Then he said: 'Alright my boy, you've finished with the marriage, now lets deal with more sensible things.' And that was really the end of my marriage. Of course, I met the young lady called Zsuzsanna a few more times but on the whole Petö was right, we finished the marriage and dealt with more sensible things.

Now, I told you this story because one had an almost religious faith in him, a belief. Not only I felt this, but also the patients, the children and the nurses, and I consider this to be a very significant healing force. Once I told him that I didn't believe in Conductive Education, in fact I still don't believe in it, but I believed in Pető. He needed an intermediary channel in order to develop his effect. At that time I saw only one positive side of Conductive Education. In other places physiotherapists exercised the children three times a day. In Pető's Institute Petö and the conductors took the trouble to deal with the children all day long, teaching them such things as how the child should hold a fork, and so all movements connected with living belonged to the therapy. It was incredibly, almost unbearably tiring to work there.

\section{Did you work there?}

No, I didn't. Look, I was invited by him to work there. I was a sort of assistant for a very short period of time, and there was a prayer wheel working there. After that I ran away. That also ended our friendship, the fact that I left after only a few weeks. I left because Petö shouted at me because I had a button missing from my uniform: 'Can't you understand that the patients' healing process will take longer if you are so slack with yourself?' In fact he was right, but I couldn't bear the strange atmosphere in the place. Anyway, I felt that the place was Petö's harem. I think that everybody was in love with him, each in their own way and style. There were lots of grotesque, embarrassing and strange situations.

Ili Székely was in charge of the conductors there. After Mária Hári she was the second most important person there. She was a great storyteller, and would tell very humorous stories about Pető. She told me a great story about a disastrous visit to the theatre to see the play 'The Journal of Anne Frank'. According to her Petö, who went to the theatre maybe four times a century, heard that it was an excellent play and bought tickets for all three of them. She told me drolly that great preparations were made.

\section{What did she mean by 'Great Preparations?'}

Mária Hári was told to put her nicest blouse on and was forbidden to come in her belted Loden coat, which she always wore, and she was also asked to leave her briefcases at home. She always carried two enormous briefcases with her wherever she went.

\section{What did she carry around in them?}

All sorts of things. As you'll hear, some very strange things. And lots of books, exercise books, which she considered important, and many other things. But as it turned out, nothing went according to plan. Mária forgot to wear the blouse elegant she had been asked to, and Petö decided that she would have to keep her belted Loden coat on throughout the performance, and so they didn't leave it at the cloakroom. But the ticket collector didn't want to let her in with her coat on, until Petö suddenly shouted 'She's rheumatic, she can't take it off!' and shoved her aside. The briefcases were put down beside their seats and in the middle of the performance, naturally during one of the lyric bits, an alarm clock suddenly went off in one of them! 
It was a big alarm clock, the kind one normally sees in kitchens, she had it because she didn't wear a watch, and so put it on the lectern when she was lecturing students. So, this alarm clock went off in the dark theatre, and she started frantically searching through her briefcase for it, while the performance practically came to a standstill. Finally she found the alarm clock and stopped it. The performance resumed, and for at least five minutes Petö didn't say anything, but that was only because he was speechless with rage. At last, he recovered his breath and bellowed 'Out, get out of here!' Naturally this caused another scandal, because he shouted in the middle of the performance.

I don't know if Palotás would talk to you about Petö's relationships with women, he knows more because he spent more time there. In any case, he had a strange relationship to women.

\section{What was strange about it?}

In what way was it strange? I think that Petö was a pasha or something like that, he really treated women as is they were his harem. They served him faithfully and he took the maximum possible advantage of it. Without the slightest bad feeling. At the same time he could also be frightened of women. There was one woman, for example, whom he couldn't get rid of. I know I am very indiscreet, but I don't like to be dishonest, in any case Petö gave her some sort of monthly allowance and Gábor Palotás had the task of taking it to her. The woman would always say lots on indecent things about Pető when she opened the door, but she would accept the money. After this scene he would go back. 'Have you given her the money?' Petô asked. 'Yes' Gábor answered.

\section{And why did she get the monthly allowance? To keep away from Petö?}

Yes. And to not make a scandal. That's really why she got the monthly allowance. Petö was afraid of her. But still, he always asked Gábor: 'And what did she say?' 'I'm not going to tell you, Doctor Pető, because you'll get all excited.' 'I can imagine!' retorted Pető, 'Don't tell me.' So this was a little monthly ritual.

\section{If at that time he had his harem, then what force keeps the Institute running today?}

Look, I think that it is the method itself. Four men of genius discover a new method of teaching mathematics. And they teach it as fanatics. The Ministry of Education accepts the method, and then it is taught all over the country by bored and indifferent teachers. Then it is shown that the new method is no better than the old method. Because the personal factor is missing.

Pető's abilities were simply incomparable. Mária Hári was also a fanatic, and I think that there are still Petö fanatics in existence to the present day. This somehow radiates through. What I am trying to say is that if a fanatic believer does something, then they create something. Today, as I look back as an old university professor, I'm convinced that Petö was an excellent man, and he was far ahead of the others in limbering up spastic patients. He could achieve a relaxing, a loosening. We cannot achieve better results by other methods. He really got results with spastic patients, and although I know that this is not a very nice thing to say, his method achieves results because it is done by fanatics, no-one else could do it, only fanatics. It has to be done 24 hours a day, and only fanatics can bear that, and fanatics have very powerful, magnetic personalities, and this has an influence. This is a very interesting mechanism in the working of the method. But if we look at the results, at what happens to those who spent time in the Pető Institute, do they skip around so happily? 
No. I have talked to an ex-Heine-Medin patient, and he said that the method didn't help with his walking at all. But it did teach him how to live.

Yes, it taught them how to live. Take a Jehovah's Witness, anywhere in the world. The world is unchanged by him. But the belief of the Jehovah's Witnesses is not weakened by this, they do not lose their faith. The question is: what is the psychological basis for this?

I don't want to denigrate him. Petö didn't in fact like movement therapy. I don't know whether anyone else was honest enough to tell you that. But he did not enjoy doing it. But it was his destiny, his life was shaped like that, so he had to do it. He had an invitation in his drawer to the University in Zurich, and another one to the University of Jerusalem. He once used to travel a lot, all around the world. When I asked him why he didn't travel any more, he always said: 'My boy, this work is so difficult for me to do. I hate doing it so much, that I can't go further than Soroksár (an outlying district of Budapest) because if I did then I would not come back.' 'Doctor Petö, if it is so difficult for you, then why do you do it?' I asked. 'Precisely because it is difficult. If I didn't do it, then something worse would come along instead. Or I would have a coronary. One has to do that which is difficult for one. Buddha said that if you have to swallow a bread roll, and you spit it out, then it will return to your mouth, again and again, a hundred or two hundred times, just always with a more bitter taste.' You see, he didn't want that bitterness, and that is the quintessence of his personality. So he was not an enthusiastic movement therapist.

I have been to India several times, as well as to Istanbul. Petö's was a mystical personality, and he never hid that for a second. Some people understood it, and some people considered him a lunatic. It was combined with a fantastic degree of education and erudition. Some people found him interesting, others didn't. I took him seriously. He was a peculiar, unconventional person who lived like a stranger in our midst, and he was led by his destiny. A solitary magus or a monk. There was a little of everything in him. And sometimes he created such farcical, absurd situations. I could talk to you about him until dawn, but you had better ask me some more questions.

\section{We've lost the thread a bit. Why did he choose movement therapy?}

I think that Pető's career didn't go very well. I don't even know how he met Gusztáv Bárczi when he returned to Hungary. And when he was not accepted into the medical establishment, he noticed a hiatus. Palotás knows this better, he was there. I only know that in Csalogány Street, where the old College used to be, he already taught movement therapy. The Institute didn't yet exist then. What kinds of impairments can one have? Mental, hearing, sight, speech - what else is there? Maybe they discovered then that no-one was in charge of movement therapy. Maybe Pető offered to do it then.

As far as I know, during the war Kun had a commission from the International Red Cross in Orsó Street. There were children there from March 1944 until February 1945. He never left the place; he was always with the children. And I think that Kun was a child neurologist.

At that time, neurological psychiatry had not yet been divided into two fields. I know that during the anti-Semitic period Kun and my uncle, who was a laboratory intern, founded a surgery, a private surgery. Kun as a psychiatrist and neurologist and my uncle as specialist in internal diseases and a laboratory Doctor. The two of them almost made up a complete hospital. They wanted to make their living from it.

\section{This was on Pozsonyi Road, wasn't it?}

Yes, somewhere there, although few patients went there. I heard that my uncle, who was a bacteriologist once, was very shocked because Kun cooked potatoes in the steriliser! 
I can also tell you another story, which I heard. It's really Miklós Kun's story. Look, we are all great storytellers, and of course we exaggerate a little, all of us, Kun, Palotás and I. It's all part of it.

Anyway, I heard the following version: at the time Petö worked as a pulmonologist in Paris. He had a small pulmonological clinic or hospital. Kun told me that he had done Pető a favour once there, in Paris. You should know something about Kun, he didn't just travel for the sake of it, he was the messenger for the illegal party as well.

He doesn't boast about it today, but I still think that it's quite an honour. Anyway, he travelled in Western Europe a lot, and he once did a favour for Petö, and Petö told him that he would repay him someday. I believe this story, because it has a similar flavour to the story of making the bed with love, by which I mean that the rarest thing in the world is altruistic love. Kun replied 'OK, I'll take a raincheck on it.' And then in 1939 Kun was expelled from France when the war started.

\section{Did Kun live there?}

He was there at the time. I don't know exactly, but of his circle of friends Árpád Mezei and Imre Pán lived there later. Anyway, he said that he had to leave Paris.

One morning Kun went to see Pető, had breakfast there, read the paper and then told Petö that he had been expelled from the country and had to go home. Petö wished him all the best. And then Kun said 'I've got a request to make: would you come with me?' Petö was shocked. 'How come?' 'Because I'm frightened,' said Kun, 'that if you are not there with me then I will not survive this war.' 'You're completely mad' replied Petö. 'How can I, a Jew, go home to Hungary?' 'That is my request,' said Kun, 'because you promised that you would repay me the favour I did you.' Petô said that no gentleman would ask such a thing. 'That's no problem,' he replied, 'I still ask it.' And Pető came back to Hungary.

\section{I've heard that story a little differently.}

How?

It was told about Gönczi. Gönczi was frightened and depressed, and went to see Kun for treatment. During one of the treatments, Kun suggested to Gönczi to go to Paris if he was frightened. And Gönczi brought Petö home.

Well, didn't I tell you that we're all big storytellers? I don't know now which is correct. Anyway, they all have the same conclusion, for some reason Petö came back to Hungary in the end. It was utter stupidity.

In order not to miss.....

That's right. The train to Auschwitz. I heard a story from my mother, that Petö had a lover in Buda who rang him and said that she was filled with anguish. Petö told her to cross over the Danube to Pest. But in the meantime all the bridges were blown up, and the woman died. So there are such stories as well.

He also had a wife.

He lost her.

The second day after their marriage.

Doctor Pető never talked about his life. I only ever heard him tell two stories about himself. One, when I once asked him whether he had ever had a wife. 'Yes' he said. 'Where?' I asked. 
He answered in his typical way that he had lost her. 'How can one lose a wife?' He answered angrily 'Well, she got left behind somehow. Leave me alone now.'

The other story that he told me is that he was originally from Szombathely and that his father was paralysed. At nights he always had to be walked to the loo. There is a pointer to movement therapy here. Every night as an adolescent he woke up and listened to the sound of his mother scolding his father as she walked him to the loo. Peto also told me that he was himself a literary man, and a correspondent for Pester Lloyd. He got a scholarship from the magazine to read literature at the University of Vienna. But I think that it surprises even you that when he went to Vienna he applied to the medical faculty instead of the faculty of arts. He later realised that the whole thing happened in order for him to survive the First World War. Because that was the only way that he could have survived it, according to him.

\section{By choosing the medical faculty, you mean?}

Yes. Because he chose the medical faculty and was connected with public health care. Because of this he was not sent to the front line. I also know that he started working at the Institute if Physiology in Vienna, but I don't know any more than that. Look, I wasn't interested in Pető because of all this, but because he was an Oriental Man. I think that he was a Mahajana Buddhist or something like that, his world view was close to that, anyway. I also think that he had a lot of spiritual interests and knowledge, which went beyond the average European. Later when I travelled in India I was touched by a similar sort of atmosphere to that which used to radiate out from Petö. Looking at him from this point of view all that I've told you so far has just been a lot of silly anecdotes. It is quite simply that he looked at the world from a different perspective and he was not bothered by or worried about such petty things. I think this because of, for example, Sándor Török, who went from being a good writer to being a bad one because he started teaching. He became an anthroposophist. He was once the head of the Christian Jews Association, and then he met Mária Göllner and Mrs Emil Nagy and became an anthroposophist - later he even became the leader of anthroposophy in Hungary. I introduced them to each other. Török even wrote about Petö in his book 'I would have liked a little garden, ${ }^{188}$ but only bits and pieces. That was a great meeting, but they excluded me from it, to my great sadness. The two met regularly in Petö's last year. It was easy for them to exclude me because Pető had become very upset with me.

\section{Because you left the Institute?}

Interestingly enough, even before that. Petö was a man in whom one could have an almost religious belief. For example one night my mother was taken to hospital with suspected nephrosis. It's a serious kidney disease. I went to Pető and told him. He was silent for a long time and then suddenly said that my mother did not have nephrosis. 'How do you know?' I asked. 'I know it, because if she did, then I would already be at her bedside.' And in fact she really didn't have it.

Later, when I married for the second time, Pető came to see us. That was a great honour for our humble establishment. He stated 'This is going to be a better marriage; it will last for at least five years.' It actually did last for five years, and it was good. So we had faith in Pető. I trusted him that my mother was going to be all right, and I didn't go to see any more Doctors. Once he came to me and said with paternal affection 'I hear, my boy that you've got a new

\footnotetext{
${ }^{188}$ Sándor Török: Egy kis kertet szerettem volna. Magvetö kiadó, 1979. pp 245-259
} 
lover.' He might have heard about her from Palotás or somebody else. 'And you haven't introduced her to me.' There was genuine sadness in his voice.

I immediately took the lady to the Institute, but first I warned her — and that was very wise of me - that Petö is an unpredictable man, and to such an extent that even I did not know what was going to happen. Because my girlfriend and I showed up quite touched, and one and a half minutes later my girlfriend was running out, with Doctor Pető chasing after her and shouting 'Get out!' I followed her from solidarity and asked her what had happened. She did not know. He simply chased her out. The following day I went to the Institute. Doctor Petö was giving a demonstration to at least twenty-five students. I sat down as if nothing had happened. I was prepared for anything. Doctor Pető suddenly stopped lecturing, stared into space for a moment, went bright red with sudden, violent anger, struck the table so hard with his fist that it almost broke and bellowed: 'Popper, that ass, brought a bitch here and introduced her as his girlfriend!' Well, the students almost wet themselves laughing. 'Hemiplegia, ...'he said, and continued his lecture where he had broken off. He had just interposed the previous sentence.

Well, I wasn't too pleased, I must admit, but I swallowed it.

So, one could go to Doctor Pető as to a guru, to a master, and he always said and did interesting things, but as a boss he was unbearable. I went to work at the Szőlő utca Institute. And Doctor Pető took offence to it.

\section{What was the Szölö street Institute like?}

It was for juvenile delinquents. I worked there with them as a psychologist. Doctor Petö didn't think much of psychology, and he could have been right. He once talked to me about the Rose test. 'My boy, this Rose test is only good for one thing on earth, and that is making money out of it.' At the time, I was teaching the Rose test in order to have some income. Or another time Petô said: 'Look, my boy, a test is a substitute for psychology. Lots of people would like to be able to play music well, but they are not talented enough. They still play. Lots of people would like to be good judges of human nature, but they are not talented enough. They are the people who use tests. If after a three hour conversation with a man you still need a test, and the result can say anything to you, then you are in the wrong profession: you are no good as a psychologist.' He had a knack for saying nice things like that.

Another time he said: 'Psychology has a hundred questions. There are ten basic questions and from each of them ten more sub-questions follow. Now I will ask you the first basic question, and its first sub-question. If you can answer, then I'll give you the next question, but it won't happen in this life, only in the next one.' Then he asked his first question, which was 'Does human individuality exist?' 'Well, that's all' he said 'think about it and if you know the answer come back and I'll ask you the second question.' But it is not such an easy question. And in this he was absolutely right, especially from his own point of view, that one is an individual. But at that time I knew very little about it, about its spiritual background, I was just very excited about it. But Doctor Pető never forgave me for going back to work among the juvenile delinquents as a psychologist. From time to time during his lectures he would stop and roar: 'Popper, that ass, has exchanged me for a Jenő Abodi!' Jenő Abodi was the headmaster of the Szőlö utca Institute, poor fellow, he was really a very insignificant person. And Petö never talked to me again in his life, after that betrayal.

I learnt worldly wisdom from Petö. He said that one cannot do important things a little bit. This is very significant and it permeated through my whole life like a chord. He said: 'Listen! One cannot do a momentous and serious thing by halves. One cannot be a little bit pregnant, a little bit syphilitic, a little bit dead. There is no little!' He asked whether I was reading a book, which could be summarised. Because any such book is not worth reading. There are things on a 
certain level, and things on a deeper level. There are things, which one can only start without hesitation. So, if you are deliberating whether or not to marry a particular woman, then don't marry her. If you can think whether you should have children or not then you shouldn't. The start can only be done unambiguously.

I believe that Petö did not believe in his own strengths. He believed that there were sometimes forces at his disposal, if he had to heal a particular patient in whose destiny it was written that he would be healed. I also felt that such forces really were available to him. But he did not believe that the force was his own, but rather that it was some superior, cosmic force. He himself was a very fallible man. And it was also something fantastic and incomprehensible to me that sometimes his placidity would be replaced by an enormous rage, and he would literally shake with anger. He really was like an Oriental Magus. He was frightening. This man could be an ascetic who ate only once a day, one piece of saveloy, and at other times he could take gluttony to its extremity. But I think he suffered because of this. He could hardly come to terms with his own intense emotions and his extreme hot-headedness.

And then I heard that he had died, and how he died. I had a really special relationship with Petö, I've really only scratched the surface now in order to give you a picture of him. I didn't go to his funeral, which wasn't well accepted at all. I didn't go. I just sat at home while his funeral took place. 



\section{DR GÁBOR PALOTÁS"'}

I'd like to ask you to recall some of the characteristics of your relationship to András Petö, some of the events that took place.

I was his assistant between 1952 and '54 at the Villányi út Institute. All his colleagues, the conductors and the whole team, were committed to him. He was a peculiar man. A unique phenomenon.

In his apartment in Stollár Street we would talk about literature day and night. If someone new came into our circle, Petö's culture and education always astonished him or her. His head was full of poems and literature. The topic of why his chosen area happened to be movement therapy came up numerous times. His answer was always that life has chosen this for him; if he hadn't chosen this, he might have been allotted something much worse.

This is why he never went abroad. We tried to persuade him: If only one person was allowed to leave the country, and no one else, it would be Petö. Why wouldn't he go and travel? He answered: 'Recently I was in Gödöllö, and people had to tell me to leave immediately, because I was going to miss the last train. I wouldn't even come back from Prague.'

There was a certain compulsory desire in him to help. On paydays he mailed lots of cheques to various people in order to help them. But money itself did not interest him. Especially not in return for treatments.

But he was happy if one of his patients gave him flowers, which he or she had made a great effort to pick.

If the person he treated was important or had influence, Petö of course took advantage of their help. If an important person came in with an aching back, he would leave with huge burdens which would weigh on him for years: for example giving help with the building of the Pető Institute.

He was very perceptive. Once he sat on a chair on the corridor of the Institute: he didn't speak, he just sat there. Mária Hári was hovering around him but he didn't speak at all. After a while he suddenly yelled:

'Gábor, come here! Fire the cook!'

I thought: 'why should I fire the cook, when he is a good, professional man?' But I didn't answer, I didn't do a thing. In the evening in his apartment, sometime around midnight when the doctor was already tired, I asked:

'Why do we have to fire the cook?'

'Because he doesn't cook well.' answered Petö, who never even tasted the food.

'Why do you think this, doctor?'

'Because today a lot of left-over food was taken back into the kitchen.'

'But not because it was bad, but because they gave so much' - I answered.

'Oh! Then don't fire him!'

Rehabilitation is never as quick and visible as an aching ear which throbs at night, the child has a fever, everyone is excited and desperate and then the doctor comes and lances the infected eardrum, the fever goes down, the pain is gone and the worried mother calms down. That is a simple, mechanical intervention. The suffering is over, everyone is happy - that is the reward. It is not like this with children who have motor disorders. Rehabilitation is a slow

${ }^{189}$ Dr Gábor Palotás (1927-1993) Doctor, director of the Institute of Logopedics 
process. Only someone who is completely committed can do it. There is not the same kind of reward as with an infected ear. Because there is no full recovery. Parents of course want this for their children. There was always some sort of a miracle. With rehabilitation, if the lessening of suffering is achieved through long and arduous work, then that is considered a great result.

In 1946-47 there was a terrible epidemic of Heine-Medin in Europe. In Denmark all medics were called in to help with the artificial respiration of the paralysed. In 1957 there was another Heine-Medin wave here as well. This is when the Children's Hospital of Buda got started - where the kindergarten of the Party used to be. All the infected children were brought there. MrsLukács was behind this, the wife of Lukács the orthopaedic doctor. The other epidemic hospital became Heim Pál Hospital, which used to be an orphanage. In America during Roosevelt's time, the largest government support was given to those infected with the polio virus, because the President himself suffered from the illness in his childhood. Later, with the discovery of vaccinations, those kinds of illnesses disappeared almost completely. Instead of them, the Little epidemic was taking its victims.

For example, because of being infected with gonorrhoea new-born babies were in danger of becoming blind, until silver-nitrate eye-drops became compulsory and in this way a law somewhat regulated the illness. Today fibroplasia causes most cases of blindness.

It was Gusztáv Bárczi who gave a home to Pető and to movement therapy. Bárczi was an extraordinary personality as well. He was an ear specialist and worked with hearing impaired people. He fought for the establishment of an Institute for the hearing impaired with Béla Török, who prepared the audiometer for the Nobel prize winner György Békésy's experiments. It was Bárczi who made the significant discovery that the early development of hearing, through the sense of speech movement, plays a huge role in the understanding of speech. ${ }^{190} \mathrm{In}$ 1937 he became director of the Institute in Alkotás Street where they were educating mentally disabled people. He puts great emphasis on the development of the vowels. In 1944 lots of Jewish children found shelter there. After the bombings, their ruined building was rebuilt and he gave a home to Pető there, from where Petö's world fame began.

At this point the phone rang and Gábor Palotás was called away to an emergency. We agreed to meet at a later date, but this was fated never to happen because of his sudden death.

${ }^{190}$ Dr Gábor Palotás: Dr Gusztáv Bárczi (1890-1964) in ‘Orvosi Hetilap’ Vol 133 No 14. pp 863-864 


\section{DR. KÁROLY ÁKOS}

How did you first meet Petö?

In 1946 a member of the Bulgarian Central Committee was brought to Hungary for treatment by Pető on a special flight by a German doctor who approached the Hungarian Medical Association to find Petö's address. The German doctor had already been to many offices without success when she came to me. At the time I worked for the Association, editing a medical journal, Magyar Orvosi Szemle (Hungarian Medical Review) I looked up Petö (about whom I had never heard of before) in the telephone directory, and told her how to get there. The following day Petö himself came to see me to find out more about the person who had been willing to give out information, and invited me for supper on the following day.

\section{What role did Petö play in Hungarian medicine?}

He played a similar role to that of Semmelweis before him. Petö was isolated, even though he did give lectures at Professor Gegesi Kiss's clinic at his request. Professor Haynal visited the Institute and as a great clinic refused to belive Petö's information that six hundred patients were treated there on a daily basis but it was true. Professor Horányi gave a successful lecture series based on a book written by the German doctor Kurt Goldstein, which he had borrowed from Pető. Nobody in the whole of Hungary had that book apart from Petö.

\section{Who was Petö's circle of friends made up of?}

I can't answer that. I have come across some of them by accident, for example Adorján Ujhelyi the radiologist. The physicist Novobatzky came to his funeral. Sándor Török and Andor Németh wrote about him.

\section{When did you first visit Petö's Institute, and what did you experience there?}

He invited me to his Institute, which was at that time in the Buda part of Budapest, in the basement of the Bárczi Institute (previously the Frim Institute) where he worked with coworkers who were mostly from the University of Medicine. Mária Hári, Werkner and, as far as I remember, Gábor Palotás who later became a professor were also there. This visit didn't leave me with any particular memories, but it did inspire me to help him with his task.

He showed us around. The Institute was full of children with Heine-Medin. Today one can hardly remember what the Heine-Medin epidemic was like. But then there were lots of children, twenty to twenty-five of them in a room, in terrible condition. You have to imagine a child whose arms were just skin and bones... Incredible, but at the same time these children were cheerful, they behaved normally, just one could not walk, another could not lift his or her arm up and so on. They did Petö's series of tasks which have later become famous. One child had his right arm paralysed, the other had her left arm, the whole group was like that. Petö thought out a task and the children had to sing: 'I am lifting my right arm, I am putting it on my head, and I am lowering it down'. In this way the child knew what task to do, namely that he (or she) was swinging his (or her) arm with his shoulder and then that skeleton arm swung up high and he (or she) only had to put his (or her) head under his (or her) arm. That was it.

I have to tell you honestly that I thought it was a load of rubbish. But later both my wife and I were there when one of these paralysed children, a seven- to eight-year old boy, took his first step in his life. Then the conductor said to the group: 'Let's count together with Joe!' And

${ }^{191}$ Dr Károly Ákos (1918) physician, psychologist, psychochronographist 
while the group was counting, Joe's paralysed leg started moving and he put it forward. He was beet-red from excitement and the whole group was screaming like the football fans at the victory of their team. And then Joe took a step."

Then I asked Petö why it was good if a child could put his paralysed arm on his (or her) head. His answer was that the particular child would be able to hold a comb with that hand and he (or she) would be able to do something with his (or her) hair which would give the feeling to the child that he (or she) is combing his (or her) hair. It was Kunsternek who first thought that a person could do certain movements even if he (or she) is paralysed because if he or she is given a light object in his (or her) hand, the joint holds it.

\section{Is this a physiological characteristic of the muscle?}

Yes, it is called tonicity. Since Pető gathered information from a remarkably wide range of sources, he used this method by Wester as well, but with that wonderful addition that the patients would not just stand but also say to themselves: 'I am standing straight'. 'I am putting my right leg forward.' - they said and then Petö taught them how to do it. One had to give an impetus to his (or her) leg, then the leg would immediately take one step. The interesting thing was that the patient did it more easily and better each time. Petö told me that the muscles would recover. I was sceptical about that, as one could imagine only with difficulty that motorfunctions could start working again, since the motor nerve-cells have been attacked by the Heine-Medin viruses and been destroyed, but nonetheless later the motor functions did recover. He said that there are reserve nerve cells that can be mobilised in their stead. Which in fact can be accepted. But how does the muscle return to functioning again? When I wrote my book on conductive education I started racking my brain over this problem. Then, as I read the special literature on the theme, I realised that by then it was already known that the nerve cells in fact function as a gland."

President Roosevelt also had Heine-Medin disease and they couldn't do anything with him. Pető would have cured him, of course. Because of Simonovits a lot of people could not walk, since he forbade Petö to treat Heine-Medin patients. He demanded that Petö show him his original degree, because Simonovits didn't believe he had one. It was as if the recovery of the patients depended on whether Petö had a degree or not. I know a lot of medical doctors who were not able to cure Heine Medin patients for example."

\section{What is your opinion of Conductive Education?}

I recommend you to read what I wrote about it in my book In the Whirlpool of Time, or Brain and Consciousness (1975). Practically speaking, Petö was ahead of his time (as Semmelweis was ahead of the bacteriological epoch that later made his work understood). Just like him, Petö was ahead of the evolution in medicine which came during the following years, in which the so-called anthropogenic co-operation, that is to say the influence of personal development, finds its role in treatment (my wife, as a senior fellow of the Psychochronographic Research Group and I have been researching this subject since 1990, gratis). The essence of this is the learnt increase in the efficiency of the human brain. Petö developed this in practice, and tried to teach it. By his apparently inexplicable (although actually of course completely rationally explainable) success he angered his colleagues and cased a reaction against himself, similar to that against Semmelweis. His success was due to the medical application of the human element in biology and ethology, which are still neglected to this day. 
What was your relationship to Conductive Education during Petö's lifetime?

He and I agreed to co-write a book on Conductive Education in three volumes. For a long period he came to collect me every Monday and took me to the Institute. Later I worked in his flat on his private collection of medical literature, of which he was very proud. He asked me for my book titled Our Nervous System, and included it in his collection.

\section{Why did Peto" never write the theory of Conductive Education?}

He did not have enough time to immerse himself in it to the required depth. Even after a decade-long friendship, my wife and I still needed several decades to complete it.

\section{What was your relationship with the Institute after Petö's death?}

I taught the theory of Conductive Education to the students in the first two years. Or at least as much of it as there was then. I also wrote the script for Bánky's film. I wrote the textbook Conductive Education volume I, the only textbook on the original Petö method, and I have almost finished two further Hungarian and an English textbook.

\section{How similar is Conductive Education today to what is was in Petö's time, and how does it differ?}

I am not in a position to say. I lack the overview. I know about some areas it changed on other directions. The name became know in many countries but this does not mean the real method's use on many occasoins. My wife and I feeled a need to develop Petö's ideas further and help everybody in understanding them if worked at that territorry. One of the most important idea of Petö coincides with the unavoidable future of the whole health care.

It is a simle calculation about the burden of the invalid children and invalid old people that it cannot be solved at all in the most modern countries either, and the global development will make the problem increasing. The Petö's method can be extended on the solution of such problems bringing about the transformation of 'incurable' cerebral palsy children, or patients of Parkinson disease or stroke ect. from laibilities of the community to its active members if the family is involved by teaching alxo them appropriately. The cost-benefit way of this assistance is associated with the feeling of the helped one (and his helper) of having a worthy life to live. We, my wife and I disribed in case of cereblral palsy children in Dina book these possibilities but maneged to publish it only in English and German and, I believe, Russian. We have completed a dictionary for conductors and parents of cerebral palsy patients called What and why? but couldn't publish it.

\section{What did you think of Petö?}

After many years of friendship with him, I would answer as follows. He was a highly educated and cultured man, and he was always ready to help. He treated all his patients, without exception, for free. Made his abilities of helping free to be learned if one wished to cooperate with him. His favourite saying was 'Duty is what the present day brings'. He was also very widely qualified and erudite. For example when everyone in Hungary was still agog with excitement about penicillin, he had already heard of cases of death due to penicillin allergy. His philosophical leanings were towards the German philosopher Baader and the socalled neo-Gnostics. In literature he preferred Franz Kafka, who was almost unknown at the time, to Thomas Mann. He had not specialised in any field of medicine and he did not have a degree in education. A friend from his youth in Vienna, Moreno, who was a famous American professor when he died, stopped in Budapest to visit Petö on his way back from Moscow. Pető told me that Moreno was disappointed with him.As Moreno was an expert of group, I told him 
that his opinion was unjust as Petö's group therapy was better than Moreno's. Petö laughed and told me that Moreno spoke about therapy but about literature, he expected that Petô will be a great German poet. His originality was not in stricks what he used if learned from everybody. The great German neurologist, Foerster for instance found not a few ways to teach lame patients to use inborn possibilities of human being to grip without muscules to stand on lame leg and so on. Petö connected these findings with teaching first of all by the use of the patient's spoken words and to do it inventionally. Perhaps the most difficult side to apply Petö's achievement was that he connected the education with the whole practical life of the patient, he taught his students to teach the patients, children and adults to become helper of others in solution of emerging problems

Let be mentioned yet about Petö's thinking of cost-benefit solutions that originally in his Institute education was not divided from the practical work: students were employed under traning, participating actively in practical conductive education and paid for it while traned at same time. 


\section{BÉLA BISZKU"'}

\section{What kind of man was Petö?}

His colleagues have surely already told you, that he suffered only his two deputies to be close to him, Mrs Székely and Mária Hári.

Did you know that he wrote psychodrama? After his death there was a rumour that they had been lost, but then later I heard that Mária Hári had them.

Well, I was a sportsman and in 1963 I injured my lower back. One of my ex-classmates, Károly Szamosi, who worked for Népszabadság ${ }^{193}$ as a Deputy editor suggested that I should go to Pető. He told me that he had come into contact with Pető. After the war, in 1945 Szamosi quite suddenly became paralysed, literally from one day to the next, and although he was taken to lots of doctors and from one institute to another, his condition didn't improve. He was walking with the aid of two crutches and had a kind of machine on his legs when he was told to go and see Petö, because he might be able to do something. So he was taken to see Petö in Alkotás Street, and as soon as he saw Szamosi he shouted: 'Take those sticks away, take that machine off, you murderers!' Szamosi had such a fright that he dropped the sticks, and although his muscles and hips had already been weakened, the machine was taken off his legs. This was his first meeting with Petö, and after that Pető started working on him. Petö stated that the cause of his paralysis was the side effects of medication. Although Szamosi had been taken to dozens of doctors, none of whom could diagnose the cause of his paralysis, Petö had only to look at him and he immediately knew the reason; the man was a genius. He had an enormous accumulation of knowledge since he received journals from all over the world, which was at that time unique.

This was of course one of his 'sins'. Since he spoke and read many languages, many of the establishment doctors disliked him and were jealous of him.

I know that many people were jealous of him, because Szamosi told me. Szamosi was treated by Petö over the course of a year, and Petö later told me, as a layman, that he had developed a system whereby the nerves running next to the flaccid muscles were stimulated, and this in turn induced the atrophied nerves and muscles to a better condition. He developed all sorts of exercises for this, and there is now quite a body of literature on the subject. I don't know how matters stand today, but then there was no real scientific proof of how all this worked, indeed this may still be missing, which is a great mistake.

Anyway, to get back to the point, I went to see Pető. Szamosi took me to his flat in Béla Stollár Street and when he saw me he asked me to jump. I told him that I couldn't, because my back hurt, but he told me to jump anyway.

When he started to treat me and I went to the Institute every morning at eight, even on Saturday and Sunday. He was an incredibly precise and painstaking man, and was always sitting at his desk when I arrived. He was very strict but also very warm-hearted. His love for children, and what he achieved for them, was fantastic, and I think he was very contented with his situation. Only a very few people stayed with him, or to put it another he only allowed a very few people to stay with him, since he had very high standards and selected people very carefully.

\footnotetext{
192 Béla Biszku (1921-2016) 1957-61: Minister of Domestic Affairs, 1961-62: Vice President of the Cabinet of Ministers 1962-78 Secretary of the Central Committee.

${ }^{193}$ Népszabadság (1956-2016): The central paper of the Hungarian Socialist Workers' Party (MSZMP) (Since 1965 the successor of the defunct Szabad Nép). The editors were nominated by the MSZMP Central Committee.
} 
So he treated me over a period of three months, and always encouraged me to believe that I would recover. He developed a course of exercises especially for me. Of course another doctor, János Balogh, a psychologist from the sports hospital who treated boxers, also helped, but it was Petö who was important, he made the real difference. After a break of a year, I have been able to take part in sports right up to today, and all this happened in 1963.

\section{How long was each treatment with Petö?}

One hour. One had to workout on a bare plank bed, on exercises to strengthen back and stomach muscles. I was also very run-down psychologically, and he even managed to get me back on an even keel in that respect. The plank bed was very hard, and the women tried very hard to persuade him to put at least a blanket on it, but he was adamant. It was at this time that I learned that anyone suffering from lower back pain should sleep on a very hard surface.

After the exercises we talked, and Pető told me - although in fact I had already heard it from others as well - that he had to fight very hard to keep his Institute independent of the Ministry of Health. I couldn't understand why this should be important to him, and he explained that it was because his treatment was basically a matter of educating the patients. I think that is correct, but that that is only part of it. Petö strove to remain independent of the Ministry of Health, because they opposed his Institute on professional grounds.

He knew everyone who was in any way connected to this subject. He even had an opinion about people whom he had never met, formed on the basis of their actions alone, and would say what sort of a person they were. Pető visited Party Headquarters and the Party Committee regularly, because I would introduce him to the people in charge of this subject.

\section{So who was in charge of it?}

As far as I remember, Miklós Óvári, who said that he would help.

After that we became friends. I invited Pető and his two colleagues, Mária Hári and Mrs Székely to my house. He therefore got to know my family, and became fond of them. He saw the circumstances in which we lived.

I can still remember exactly what he would say to me if I complained: 'what do you expect, do you only expect the good things in life? You are a happy man. You have a family. You have to be prepared not just for the good things in life, but for the tough times as well. One has to know that there is struggle and suffering in life as well.'

However, as I said, the Ministry of Culture and Education was really more sympathetic to his problems.

Petô took great pains to try and win the man in charge at the Ministry over to his side. They considered me a bit of fool to be supporting someone who was a little bit 'odd'. Although they never actually said as much, one could sense it. All of those who opposed him came from the same professional background, and supported Szentágothai. The Party Headquarters and the Ministry of Culture and Education asked for a professional opinion of Petö, and the opinion professed was that what he said that he did was impossible, and mere quackery, after all it could not be scientifically proven. I came to this conclusion at the opening of the new Petö Institute in 1985, when Szentágothai said: 'and as far as the polemic between myself and András Pető is concerned, he was right and I was wrong.'

I couldn't defend Petö's method, they were determined to officially discredit it even though the building was already standing. The Petö Institute was omitted from the official list of Universities and colleges when the new Education Act was released. I despairingly asked Judit 
Csehák ${ }^{194}$ to at least go and see the Institute, since this action would destroy it, and she should at least see firsthand the national treasure, which she was destroying. It had an international reputation and should be protected. They did compromise, but in such a way that they damaged the Institute anyhow. They formed a new college, which was really a kind of teacher training college, but the students would never even see patients during the four years they spent there.

But then Pető showed his real genius, for he made sure that they were in fact involved with the children every day, right from the beginning.

He only accepted beautiful young girls, because from the point of view of the children's healing this was of great importance. He solved the problems of the training course in practice, although it is true that this was a kind of mistake as well.

Another important point was that Petö did not let the children's relatives pay honorariums. He did not want to strip the parents financially, to take from them everything that they had. He selected the patients as well, and had a bitter fight with Bárczi about motor disabled children. Pető stated that they had perfectly sound minds, and were just hyperactive and had communication problems. He did not allow the use of special education for such children, since he said that if it were to be used then it would damage their independence. I saw the children whom he treated, and I saw their progress as well. Petö did not accept mentally disabled children in his Institute, since if he could not communicate with the children he could not achieve results.

Now, of course, they will accept anyone who can pay, but of course although they do their best with them they cannot achieve results with all of them.

A decision was made at Ministerial level about the Institute, because Petö himself formulated it with the Prime Minister's representative. Kállai was Prime Minister at the time. So he argued with Kállai that the Institute should be named the Institute of Conductive Movement Therapy. Kállai, with his pedantic style, wanted to drop the 'Conductive' in order to make it more Hungarian. But the Ministerial decision was made about the Institute ${ }^{195}$, which was the main thing.

The name should have been copyrighted, since it is very important, but now it's used all over the place.

\section{What sort of relationship did you have with Petö?}

First of all I am very grateful to him for what he did for me, and for the chance to have got to know him, because although he was outwardly a very dour man he was actually very warmhearted when he unbent. He had four separate fatal diseases, an incarcerated hydrocele, and he had terrible trouble with his stomach and he lived on a very strict diet. I often observed what he ate, and I tell you, it would have killed me! First of all everything was totally unsalted, and he ate only vegetables and potatoes, no meat at all, or only very rarely. The two Cerberuses who guarded this strict diet were Mária Hári and Mrs Székely.

\section{How did they get on with each other?}

Oh, they quarrelled all the time. Hári had a medical degree and Mrs Székely didn’t. But in practice Mrs Székely was far better with the children, she was the chief conductor. Of course medical supervision was also needed, and Mária Hári provided that.

\footnotetext{
${ }^{194}$ Judit Csehák: President of the Scientific Political Committee and the State and Kossuth Award Committees. Cabinet Deputy Chairman

${ }^{195}$ Hungarian Gazette No 36/1993 (21st December).
} 
Petö took on cases that others couldn't help with, such as the son of the footballer Robert Ilovszky, who dived into Lake Balaton in 1964 when he was 19, and broke his back. He was taken to Holland and many other countries to try and cure him, and finally ended up with Petö. The doctors had all said that nothing could be done, but Petö managed to give even such a badly paralysed man control over his bowel functioning and urination, by repeatedly hitting his stomach until the stomach muscles started functioning correctly.

Anyway, the Institute has some problems now, some things weren't really done properly, like the main entrance, although I don't understand it, when it's perfectly possible to get into other places. It wasn't Petö's fault, of course, but rather the architect's and the contractor's, but he did do the rest. Of course I was busy with other things as well at the time, and couldn't devote all my time to it, but I helped when necessary. Szamosi helped as much as he could through his contacts: he would sometimes call me, and I would sometimes call him. In the meantime, as I have mentioned, the character of the Institute changes, which is, I feel, a great pity because the theory should always be connected to the practice.

Do you think that you would have become involved with his problems had you not come into contact with Petö as a patient?

The reason I helped was not because I became ill and he helped me, but because I sympathised with and understood his aims, he made me a convert, partly through Szamosi's example, I understood that he worked and achieved results in a field where no-one else had done so before. After competing the course of exercises I understood what it was all for, and was happy to strive for such a cause. The introduction of the 'articulated intention-planting' was a fantastic thing, which happened just around the time I became acquainted with Petö: 'I put all my weight on my left leg, one two three four.'

\section{After your recovery did you keep in touch with Mrs Székely and Mária Hári?}

Yes, I did. After the political change in 1990 Mrs Székely left, earlier than Mária Hári, who retired a bit later. But I am convinced that even had I not helped, this method would have made its way forward.

How did the Ministry of Culture and Education come to adopt Petö? He always balanced on a knife-edge between the Ministry of Health and the Ministry of Culture and Education.

Oh, God save him from the Ministry of Health! He was particularly angry with the Deputy Minister at the time, a certain Simonovits ${ }^{196}$, who was dead set against the method. I don't know much about the professional dispute against him, I only know that Petö's work got results. That was why they made a film of each patient who was accepted into the Institute, so that they could prove that they had improved when they went home after the treatment. Earlier, before this method existed, such people would have died like animals in cages. I'm not saying that such people become champion runners, but they can at least get by, they look after themselves, they learn professions and that's a marvellous thing!

Who else did you know from among Petö's circle of friends?

I didn't know any of them. When I met Petö I was the secretary to the Central Committee of the Hungarian Socialist Workers' Party.

${ }^{196}$ Dr István Simonovits (1907-1985) Correspondent of the Hungarian Academy of Science. 1957-1964 Deputy Minister of Health. 
Did any of your colleagues know Petö?

I tried to persuade my colleagues at Party headquarters to become acquainted with the Institute in order that they might see for themselves what Pető was doing. They were not my colleagues in the sense that they worked directly with me, but one was the head of the department concerned with Petö. I wanted them to find out for themselves, and I thought that once they knew what obstacles had been put in his way by the bureaucracy, they would help to remove them, and make life easier for a person who was doing such work. After all, if they could see the results....

\section{And what the Central Committee's opinion of Petö?}

As a public body they had no dealings with him, not even the secretariat, it was all the province of the Civil Service, which dealt with the everyday operation of the Institute: the children's accommodation, the conductors' salaries and so forth.

As far as I know Pető had been in Austria before, as Director of a sanatorium. He never spoke about it. I do know that he went to school in Szombathely and I remember that he said he went to school with Mindszenthy. ${ }^{197}$ Pető was highly intelligent, and he had a strong poetic streak. In Vienna he met Moreno, who came to visit Petö in Budapest in 1962. He had an enormous argument with Moreno. Petö did not like the way that Moreno worked. Moreno wanted to heal his patients by letting them act out their problems. I don't want to go into details, because I only know about it all superficially. I do know that Petö invited Moreno to come here. Petö was attacked from many sides, from within his own field and from doctors, especially doctors of classical medicine.

Szamosi and I argued with Petö that he should write a book: he had all the exercises and the results, but no scientific theory, and I think that is still missing. There was an enormous body of experience but no-one really classified and categorised it. They were all too busy with the everyday practice of healing. We talked about it after Petö's death.

At the time when I was involved with Petö, Ortutay had long since been replaced by Pál Ilku in 1963. Petö knew very well who was responsible for the fate of the Institute with the Party apparatus, and how important that persons reports and opinions were. So Petö concerned himself very much with this person: he talked to him and invited him to visit the Institute. These officious officials could not endure Petö's rough style, and he had a lot of conflicts and problems with them.

Gegesi-Kiss had been Vice-Chancellor of the Medical University for a long time, and he gave Pető a chance. Gegesi was a very progressive man. He acknowledged Pető's work and results, but he kept a certain distance from Petö because of his abrasive style.

Thank you very much for the interview.

${ }^{197}$ Cardinal Mindszenthy (József Pehm, 1892-1975) Bishop of Veszprém, 1945-48 Archbishop of Esztergom. 



\section{DR LÁSZLÓ HORVÁTH"'}

In 1949 Petô worked in the Frim ${ }^{199}$ Institute, which at the time operated as the Hungarian Royal Institute for the Imbecilic, and was a public institution. I started to give lectures there because professor Kiszely cancelled his lectures and gave his place to me. Gusztáv Bárczi and I discussed what themes I should give lectures on: anatomy, biology and evolution.

Pető started out with 6 or 7 beds down in the basement. As far as I remember, Biszku ${ }^{200}$ had a son ${ }^{201}$, who was paralysed in a car accident — this was between 1950 and 1953. With his technique and method, Pető rehabilitated the boy. As a return favour, Biszku helped Pető build up an institute in a villa that he had found on Villányi Road. It had a very beautiful park around it and a new institute was built which had no doorsteps at all.

In the beginning this was where they gathered those children, who were able to go there. It was a nation-wide Institute, operating as the movement therapy department of the College of Special Education. Its director was Gusztáv Bárczi. There were meetings held at the department, and everyone would attend except for Petö. Because, in point of fact, he himself had mobility problems. He had himself driven around in a taxi, because he had hydrocele as big as a small melon. Sometimes he put it back in and it was all right for a time, but then he would stand up, and out it would come again.

I don't remember any mention of an operation, he was usually against operations, he tried to solve everything conductively. For example in the case of hyperthyreosis you had to do the following exercise: Count one-two-three-four-glaza-glaza-glaza. I don't know if it healed the children with hyperhyreosis, but he did the same thing with those who were effected with Heine-Medin or Spina bifida.

He made them stand up and 'hold the chair and step: one-two-three-four-I step forward, one-two-three-four-I step together, one-two-three-four-I step forward' And this went on from morning to night. The children got really tired, together with the conductors, but after an afternoon rest it started all over again. Merciless work - that is what it was.

His patients were quite mixed. He opened the new Institute in the 50-s, his first colleague was Mária Hári, who later actually inherited the Institute. Mária Hári took the work of directing the Institute very seriously. I thought very highly of Petö. The whole man gave a Churchill-like impression: he had two teeth in his top jaw and two in the bottom and weighed over 100 kilograms... if he had stood up straight he would have been at least $180 \mathrm{~cm}$ tall, but because of his bad posture he looked like Churchill. He was witty and he gave amazing lectures, I heard a few myself.

Once after Pető's stroke, Gusztáv Bárczi made a grave mistake: he wanted to transfer Petö's department to the orthopaedic clinic. This because Bárczi liked to work with the mentally disabled, with the hearing and the visually impaired, not with the physically disabled, or motor disabled.

I was invited to supper at Petö's house a couple of times, and once we were invited for $7 \mathrm{pm}$. We rang the doorbell. He had an old housekeeper, she showed us into the hall to wait,

\footnotetext{
${ }^{198}$ Chief physician of the Schöppf-Mérei Hospital, ex-professor and head of department at the Gusztáv Bárczi College of Special Education, presently guest-lecturer on the topics of evolution and the pathology of mental disability.

${ }^{199}$ Jakab Frim (1852-1919) special education teacher, organiser of the first Hungarian institution for the mentally disabled.

${ }^{200}$ Béla Biszku (1921-2016) Minister of home affairs between 1957 and 1961, Deputy-Chairman of the Cabinet (1961-62), Secretary of the Central Committee (1962-79).

${ }^{201}$ Biszku actually has four daughters.
} 
and said that the doctor would come in a short while. We waited some 15 minutes, and then we were already thinking we had come to the wrong place. The woman opened the door and I saw that doctor Petö was sitting in his room reading a newspaper. Strange. I started to speak louder and he came out: 'Doctor Horváth! Let me tell you that if you see couples walking around in England you will see that they ring the doorbell at exactly 7, when Big Ben tolls. You are fifteen minutes late.' Well. I lit a cigarette. 'Where are you putting the ashes, here's an ashtray!'

'Well,' I said, 'we are not in England.'

'All right, well, sit down.'

Then dinner was served and we talked of many different things, for example we spent a good while discussing Eastern medicine. He said to me: 'We should send someone to China to learn acupuncture.' I said I wasn't exactly dying to go to the People's Republic of China, but I would like to find out about acupuncture somehow. Even if not in practice, it would be good at least to know about it in theory. If I prick certain points, I see phenomena that are hard to understand according to current medical thinking of today. (This was in the 1950-s.) Then he showed me a diagram where a fat Chinese man sat cross-legged, and there were various points marked on him. Among other things, there was a point in between two incisors, and pricking that made gallbladder pain go away. I somehow could not understand that. 'You have to prick in here?' 'Yes, it is written down.' he answered. 'But what is the nerve connection?' I asked. 'I do not know,' said Pető. Later, I was called out to a case, an old lady, on the second day after Easter. Well, they had eaten too much, she had a bilious attack and I had absolutely nothing on me. I asked for a knitting needle, I took it and poked it into the indicated point and her pain ceased immediately.

Pető wasn't excited by the religion, but rather by the several-thousand-year-old healing methods of Chinese and Hindu acupuncture and acupressure that was based on folk traditions.

\section{This was not known in Hungary in Petö's time?}

No, it was not, if one only heard the word: acupuncture, then one just smiled. But when I had a real experience of the pressure relieving the cramp like that it impressed me greatly.

\section{How widely were these ideas of Petö accepted?}

Nobody accepted it. Witch-doctoring. In the final analysis he was not a witch doctor, he did have a medical degree. I saw it, he received it in Vienna. My teaching assistant was in the personnel department of the College, and since everyone had to turn in their diplomas, Petö did as well, and I could see the certificate of his degree in pneumonology. So why did people say such things anyway? Well, because Pető had enemies.

Gábor Palotás, who was an irreplaceable man, told me the following story: He worked for Petô for a long time. Once he somehow didn't put the foot of a child in the correct 1-2-3-4-Istep- way, and Pető yelled at him: 'Doctor Palotás leaves the room. The lawn needs trimming!' - There were bricks out there, cement blocks, and between the blocks the asphalt didn't bond properly, the grass grew up, the roots started to strengthen, and it made the pavement wobbly. The children couldn't walk straight on it. This was the grass that had to be pulled up. 'You go and weed the grass right now!'

Palotás was pulling grass in his white coat for a week, but by chance a delegation came from the ministry, and they asked: 'Gábor, what are you doing?!' 'I am pulling the grass up.' 'And what possesses you to do that?' 'The boss told me to...'

There were lightning changes in him. For example he noticed after lunch that there was grenadine, and almost all the food was left on the plates. 'Where is the cook? Take your papers, 
and good-bye, I don't want to see you here tomorrow.' 'Why?' the cook asked. 'Look at this! What you made, the children won't eat! Then you are not a good cook.'

But he didn't know who was going to cook the day after that. He was this kind of man...

And Auntie Ilus, who was the wife of a cashiered colonel, couldn't get hired anywhere else but he took her on. And it was she who told me, how the employees started to cook after that instead of the cook who had been fired in the blink of an eye.

Yes, he was a very peculiar man. To show just how peculiar he was, I will tell you a story, which he told me about himself once. 'It was minus 3 or 4 Celsius, a pleasant winter day in Vienna, and it was snowing. I wore a good winter fur coat and went to buy a newspaper. The newsboy was there, in bad shoes, maybe they were galoshes, but the water had got into them. He was digging his hands into the pocket of his jacket, and you could tell he was not happy.

I said: 'Schönes Wetter haben wir heute. Nichtwar?' 'Ja, mein Herr.' he answered. And then I saw that the boy was cold. I took my fur coat off, hung it on him and ran away.'

He was like that. I can imagine him praising the weather while the other one is cold.

\section{Did you become friends?}

No, he had virtually no friends. He always kept himself isolated.

\section{Where did the idea of his movement therapy come from?}

I suspect he had been to Switzerland and knew Dalcroze's School of Dance and Movement Art. ${ }^{202}$ I think that that school educated through movement art and worked with a few motor disordered children.

The TB Sanatorium where Petö worked cured its patients with movement therapy.

Yes, that would make sense, that he started to teach in his new ways under the influences of Swiss impressions. And then there is the Bobat-system in England, which is similar to Petö's, but it is not the same. Petö always counted in the conductive way, so that the child would know he had to do something when he got to five. He could prepare for the movement, for the task at hand.

Pető taught Mari Hári and she continued on with it. Mari Hári adored Petö, she thought he was wonderful. But this, of course was not requited.

\section{Do you know the theatre-story with the alarm clock?}

Yes, Popper and Mrs Székely both told me.

There was a boy who drove the children back and forth. He couldn't say 'r.' Whenever he met Petö he had to say 'good morrning dearrr sirrr, deerrr, deerrr, duurr, duurr,' (he had to be conditioned). Once the phone was ringing when Petö entered the room, and the boy picked up the phone and said: 'Good morrning dearr sirr! deerrr, deerrr, duurr, duurr' Petö yelled at him: 'You moron! What would the caller think, what kind of an Institute is this?'

Pető had enemies as well. But Ortutay and later Biszku protected him, Petö treated motor disorder and lack of motor function with conductive education, which is very strange and one could easily find fault with it, and people definitely did. There is definitely a need for it, because the requirement and pressure of society are so great, that even the institute they built on Kútvölgyi Road proved to be too small. Pető was involved in the planning but it was not

\footnotetext{
202 Émile Jaques-Dalcroze (1865-1950) Viennese born Swiss music teacher. In 1911 he opened his school in Hellerau, and then continued his experimental movement courses in Laxemburg, near Vienna, after the first World War.
} 
built as he would have wanted it, not with that many staircases! The one on Villány ut they managed to make without any doorsteps.

\section{How active a role did he play in the education of conductors?}

Well, at one point, this was Bárczi's concept, a Special Education teacher had to be good at everything: mentally disabled, hearing and visually disabled, those who had difficulties integrating into society, and also emotional and behavioural disabilities and with patients with lack of motor function. Consequently, the finals in the College consisted of questions on general therapeutic problems, and then came all the separate topics.

\section{But there are often motor disabled children who cannot talk either.}

Yes, those with more than one disability. And this is where the problem is: in Hungary there is no institution for them. Instead there is always this so-called ' $D$ ' department. So if somebody is blind and mentally disabled, they will be placed there. If somebody is deaf and mentally disabled, or blind and deaf, meaning, it is really hard to communicate with him or her, where are you going to place them? There are no institutions. In the West it is completely different and totally bad. There you have teachers who have studied treating the blind and teaching geography, so they will go to the Institute for the Blind to teach geography. We don't have that. Studying to treat the blind means you will have to teach something or other - you will have to pick it up as you go along.

When the department became an independent institute, Bárczi wanted to pass it over to the Orthopaedic Clinic. It was already a national Institution. Orthopaedic doctors operate on everything, while Petö didn't operate on anything at all. He always healed with the conductive method. After that he hated Bárczi a great deal. Even after he was already paralysed he worked on at the Institute with unbelievable will power. I had dinner with him when he was paralysed, and he took a knife and cut the meat with it.

The department separated from the College of Special Education and became a college in itself. While we were still together in what is now the Gusztáv Bárczi College for Special Education, we met quite often. He was able to set up his Institution as an independent college with the help of his political connections. I think Biszku played a great part in this.

\section{Who stayed with Petö besides Mária Hári?}

No doctors did, they couldn't stand him. Only those stayed who were emotionally connected to him.

He fired people at the drop of a hat. But his results were fantastic. Once he told me the following story: 'I was shouting after a man: 'Give me your ticket!' 'What ticket? Why, what did I do?' 'You were running after the tram, but you didn't catch it.' He had a ticket. 'Give me your ticket!' And he handed it to Pető humbly. 'I apologise, doctor Pető, I didn't know it was you shouting after me.'

This man who ran after the tram had a serious case of multiple sclerosis. So tell me, was the diagnosis wrong or did Petö work wonders with the patients? He was a young man and he ran after the tram.

Pető was a strange man. He kept the ticket of this young man as a souvenir. He had charisma.

Or this story: He is looking at his audience during a lecture and says: 'Zibsits, stand up!' The man was called Ibsits. 'Excuse me, my name is Ibsits...' 'What does it matter what your name is? Sense of identity, what is it for?' 'You can't be saying that seriously' 'Oh yes, I can.' 
Or the following: He smoked a cigar, he was always smoking cigars, and he was a Churchill-like figure. He took care not to leave any dirt behind. He smoked even when lecturing and somehow on the 7th of November we had to commemorate the Great Soviet Socialist Revolution. He gave a lecture and spoke of nothing else but movement therapy. At the end he said: 'Please know, that the Great Soviet Socialist Revolution and movement therapy are one and the same thing.' He took the full ashtray, put it in his pocket and left the room.

\section{Where did he stand politically?}

You couldn't tell. We talked of many different things, but not of that. Not all the people in leading positions were party members. For example I was head teacher of our department without being a member. This was after the year when the Communist Party lost power and the whole political system changed. From 1950 to'53 I was a peripatetic teacher. Bárczi told me he could save the College of Special Education only if an anatomist or biologist working with Pavlov's reflexology took the position of headmaster teacher. I was an assistant teacher at the university, Törö was the professor. I didn't have a good relationship with him, so I said yes to Bárczi's offer of the headmaster's position in 1953. At the time everyone was writing their theses on Pavlov's reflexology.

To return to Pető... In 1945 Bárczi was hiding Jewish children in the Institute. Pető was also already there. Later in the 60s Miklós Kun ${ }^{203}$ applied to head the Mental Pathology Institute of the College of Special Education. The heads of departments met to discuss the application. Petö, who was then already leader of the Movement sciences department, exceptionally came to this meeting and stated: 'I came, because he is my brother and I am grateful to him for many things and he must be successful' (dixi et salvavi animam meam) I spoke and saved my soul).

Petö was ready to work with anyone, it didn't matter if they had money or not. There were people he could heal, and others he could not. For example, a child with spina bifida and incontinence - well, he worked with them effectively as well. From this point of view he was a saint.

${ }^{203}$ Miklós Kun, psychiatrist. 



\section{DR. KATALIN HIDVÉGI ${ }^{\text {"m }}$}

I went to the Petö Institute in 1954 as a patient, as far as I can remember at the recommendation of Professor Károly Walter of the Szeged Children's Clinic. I was 14 then. At the time they did not only treat mentally disabled children, but were also experimenting with the effects of physical and dietary therapy on all kinds of disabled children and even epileptics.

At that time the Villányi street institute was live-in, and applicants were accepted on a firstcome basis.

I don't know what the total number of people at the Institute was, but I think about eighty. There were some outpatients aged from three to five, and there were also some elderly cerebral haemorrhage patients as well, all of the patients were categorised by age and diagnosis.

The group of which I was a member was aged from three to fourteen. There were fourteen of us in a big dormitory. The furniture consisted of fourteen plank bunkbeds and fourteen blankets. In the evenings a blanket was spread on the bunkbed, a sheet was laid on top of it, followed by another sheet and finally a blanket. There was no pillow. The assistants took great pains to ensure that everyone slept in an ideal position with extended limbs and either on their backs or on their fronts. If someone turned on their side or drew up their legs then they carefully woke them up and straitened them out nicely. If someone couldn't straighten their legs then various sandbags were used to keep them in an ideal position. At night two assistants looked after us, during the day at least eight people looked after us alone. Naturally there were also nurses, conductors and cleaners.

How were the conductors different from the nurses?

The nurses were concerned with our bodily needs, that is they fed us, gave us drinks and bathed us. The conductors performed the exercises.

Were the conductors trained physiotherapists, or did Petö train them according to his own personal theories?

Presumably, they had some basic physiotherapist training. That is not something a fourteenyear-old child would know, but at the time there was no formal conductor training in Hungary. They were taught how to direct and conduct the exercise. Probably they learnt a lot, while doing the exercises with us.

Our daily routine was quite military. We were woken at six. Their aim was for all of we children, as far as we were able, to look after ourselves, that is to say that we children had to dress and wash ourselves, brush our own teeth, put away our own bedding and possibly help the assistants put away the beds.

In the Institute there were, you understand, no separate spaces for dormitories, dayrooms and physiotherapy, rather we slept, ate, worked and spent our entire day in the same room.

There were also chairs, and they brought in tables for mealtimes, or rather during the day they were stacked against the walls, like the bunkbeds, to make room. The blankets were spread on the floor and we did our exercises on them. We had to finish dressing, washing and eating breakfast by eight o'clock each morning.

\footnotetext{
${ }^{204}$ Dr. Katalin Hidvégi (1940) chiefdoctor in a Social Home of eldery
} 
Occasionally, we didn't eat there but the tables were set up in the so-called out-patient's department and we had to go there, or rather they took those of us who couldn't walk, since there were, of course, some such in our group.

Here they laid such total stress on the development of independence that even someone whose hands were paralyzed had to try and look after himself or herself.

\section{How could this be done?}

Either they would wedge a hairbrush in between the planks of a bunkbed, and then one could brush one's hair by moving one's head against it, or they struggled somehow to complete the action with their limited movement. The conductors were most strictly forbidden to help us in satisfying our physical needs. But in the last ten minutes before eight they started to help and naturally nobody stayed hungry. But as far as it was possible everybody had to complete his own task on his own, each of us had to serve ourselves out of the common dish or pour out of the water jug by our own efforts. If the child was hyperactive, then he might miss his glass, might have even miss it twenty five times. One day we ate with our right hands, the following day with the left, in order that we could use our hands in the same way, or we had to use our paralyzed limb just as well on the given day. This was done with such strictness, that there was a sign put out on the table, with "TODAY WE ARE EATING WITH OUR RIGHT HANDS" written on it in big capital letters. The following day they changed the sign and then "TODAY WE ARE EATING WITH OUR LEFT HANDS" was written on it. This was very seriously supervised and if by any chance someone wanted to use his healthy arm without permission, he was punished by expulsion from the institute. This happened to me once.

\section{How did it happen?}

My parents were informed that I was sent away because of disobedience. Then my mother came to the institute and begged them to allow me to stay. That time I was forgiven.

\section{Was it usual for one to be forgiven for the first offence?}

Yes, for the first time, but then there were two further times when I was expelled as well. Once because one morning it was past eight o'clock and by that time one had to be lying down flat on the blanket, waiting for the beginning of the physiotherapy, but I was found standing by a table; I was busy writing. I was helping the nurse to complete some small statistics, for example I put a cross whether somebody had moved their bowels or not. But by this time it was past eight o'clock, and the nurse was reprimanded, and I was expelled. The story of the other case was as follows: after lunch between two and four there was siesta, which should have meant sleep for everybody, but I was reading Shakespeare's fairy tales under the blanket. When this was discovered, I was expelled again. Of course I was accepted back once again. An expulsion like that lasted not only for a few days, but for several months. You had to go home and get registered and then you were accepted again.

But I will go on describing the course of a typical day. As I already said, one had to be ready by eight o'clock, dressed and finished with breakfast. From eight to noon there were prescribed floor exercises for 50 minutes. The nurse said what we had to do and we had to say slowly, articulated and clearly: I am lifting up my right arm, one, two, three, four, five. I am holding it, one, two, three, four, five. I am lowering it down, one, two, three, four, five. You were not allowed to just drop it back. As many times it fell down, so many times you had to lift it up again to the same height, as it fell from, and then you started from the beginning. Usually we repeated the exercises until everybody in the group could achieve the desired goal. Which 
meant ten, fifteen, twenty times, one after another. These exercises were designed to make all muscle groups work systematically.

There were ten-minute breaks between lessons, then you could go to the toilet or drink a glass of water. During the exercises it was strictly forbidden to go out to the loo, you had to hold it back. If you definitely couldn't hold it back, then you had to urinate in your clothes, but you had to continue with the exercises until the break. So there were exercises until twelve, sometimes till only eleven, and then walking exercises followed. Somehow everybody got to the vertical position. Even if they couldn't stand unaided at all. There were chairs with high backs, and even if only with the help and support of three nurses, we all got into vertical position, and then the walking exercises followed in such a way, that the chairs were moved forward and we had somehow to carry our bodies after them.

\section{What was your condition like when you got to the institute?}

At that time I was only able to walk with the help of a stick, as my left leg was completely paralysed and the right one was partially paralysed. Even with a stick I could only walk by throwing out my legs. When I left the institute I was even able to cover a certain distance on a flat road without the aid of a stick. It is now known that I was not an ideal patient for conductive therapy, today it is widely known that the method is not suitable for cases of peripheral myoplegia. But probably during that time my healthy muscles were strengthened to an extent which had a positive effect on my walking. But I consider something else more significant... but I'll leave that for later.

I'll go on with the flow of the day. Well, after the walking exercises we had lunch. That was special. Since they were trying to feed us in the richest possible way in calories, minerals and vitamins, only those who had worked exceptionally well during the week were treated to soup, but even then only once a week, or maybe on Sundays as well. The meal started with a big dish of raw vegetables, cut up carrots, lettuce and other kinds of green vegetables full of vitamins, we had to eat them first. Then came the main course, rich in protein. In order for us not to gain weight we did not get a lot of sweets, only on outstanding occasions such as festivals, birthdays and namedays. A tin pot was brought in full of mixed fruit drops and Kati, one of the conductors gave one to everyone.

But we got a lot of ham, cheese and sour cream, e.g. for tea a glass of sour cream with quarter of a pound of ham, without any bread. At lunchtime, after having eaten the vegetables, everybody had to tip their heads back and the nurses poured down a tablespoon full of calcium, a few vitamin pills and a spoonful of cod-liver oil. The clever ones did not swallow it immediately, they tried hard to keep it in their mouths and then to go to the bathroom and spit it out there. Naturally being children we did not know that did no good to flush the toilets, the oil floated up again to the surface. The conductors checked the bathrooms and if there was any oil floating on the water, they poured cod-liver oil down all our throats again. There was siesta after lunch, two hours afternoon sleep. We were not allowed to talk or read.

Later there were lessons during this time, because while I was there at the institute education had not been introduced yet. At that time I was already a first year student in a grammar school, and I managed to continue my studies in such a way that I took the exams separately at the end of March. From the beginning of April to the end of October I was in the institute, and then I went back to school again. Later some teachers from a primary school near by went regularly to the institute to give lessons that took place in the afternoons.

In the afternoons there was an hour of walking exercises and for example to improve our sense of balance they would put a breadbasket on our heads which was not allowed to fall down. If it did fall, 
the breadbasket was put back on the student's head again and they were reminded that they were not careful enough and should be more careful next time. This lasted until five.

At six we had supper. As the calorie rich tea had been at four, for supper we got very light vegetable purees, on Monday spinach, Tuesday sorrel, Wednesday mixed vegetables, and then again sorrel, spinach and mixed vegetables. During that time I had enough vegetables for the rest of my life.

\section{Haven't you eaten any since?}

No, not since then. I can cope with mixed vegetable salad, but I cannot even look at spinach or sorrel. Well, so in the evening we always had such a light supper. After supper we had free time, when the conductors read stories, arranged games for all of us and during this time we could write letters or read, and as far as I remember we had to go to bed at nine.

\section{Were the conductors there with you?}

Presumably they had their own families, but in practice they were always there. I know that a few of them lived on their own, that is the reason why they worked from dawn to dusk. For example the physical exercises teachers used to go home but some of the self-sacrificing ones, such as Erzsi or Kati practically never went home. There was a flute course arranged for those who had arm disorder or could move their hands with difficulty, and already while I was there one well-known flute artist from the Opera House gave us lessons twice a week.

Theoretically only those of us could have flute lessons, whose arms were paralysed, but unofficially a few other children who could move their fingers well also took part in the lessons, among them András Pernye who came to like Blockflöte there. I was also in this group and when we had visitors we had to perform. Those who could play really well were taken to the Opera House, which was how I got to go there for the first time in my life, to see Madam Butterfly. Five of us were taken then, and we as teenagers wanted to get beautifully dressed, to put our civil clothes on. But in the afternoon three head physicians appeared and got us dressed in our chequered uniforms, we put our cork-soled shoes on, and we were told that we should be proud of being Movement Therapy Institute patients and not be fussy about such superfluous matters. We were taken by taxi and in the interval the conductor was asked to come and see us, and talked to us about the beauty of music and the magnificence of opera. I managed to get to the Opera three times and my love for music may have had its foundation there.

I would also like to mention that the institute had already started to get an international reputation while I was there, and all sorts of foreign groups visited us to see the exercises. This was extremely unpleasant and embarrassing for the adolescents because, although on other occasions boys and girls were separated, for the presentations in the so-called out-patients' department co-educational groups were formed, which meant that boys and girls were together. As they wanted to observe the movement of our muscles more clearly, we were naked. At the age of fourteen to fifteen it was very difficult to become accustomed to exercising naked in mixed groups, and I always felt ashamed and discomforted. For me at least the performances in the outpatients' department, when we were undressed out of professional reasons, were sources of great pain.

Among the doctors I can definitely remember Doctor Petö, who was already an elderly, short and squat man. As a child I considered him a very strict man, who was determined to improve my movement and I was convinced that he could help. He did not tolerate any slackness, untidiness or misbehaviour, or failing to complete the exercises. If someone did not behave properly they were punished, even to the extent of not being allowed to meet their visitors during the monthly visiting time, even if the visitors had travelled up from the country. 
This happened to me once. The porter gave a little lecture to my parents to the effect that rules are rules, and they were not allowed to see me. These visits, which were only once a month, could easily be forfeited. He was a practically incorruptible man.

\section{Dr. Petö or the porter?}

Both of them. Dr. Pető would not even accept a bouquet of flowers from my mother. Dr. Mária Hári also worked there, and she tried to live up to Dr. Pető's expectations to the maximum extend possible. We - with our teenage minds - thought that she had no soul. She - as everyone else - was also always very strict. But once, on the evening of a day when we children performed a play in a festival, she put her arms around me warmly, and thanked me for my performance. This was the only manifestation of emotion that she ever gave.

\section{Were you present on the occasion when Dr. Petö was taken ill during exercises?}

Yes. He conducted the exercises in the outpatients department when demonstrations were given. I can only remember that he started gasping for breath whilst conducting an exercise that "I am lifting my left arm", during which the conductors always did the movement with us, and he was unable to complete the exercise. The following year when I went back to the Institute I heard that he had had a cerebral haemorrhage, and had been off sick, doing his own exercises at home, and that he had had impressive results in his own rehabilitation. He returned after a year and I, as a child, could not detect any significant change in him. He did the exercises at home with great results. What he expected from others, he had to expect from himself as well!

Later I became a doctor myself. And I now understand that although my paralysed muscles were not improved, I was taught to make much better use of my usable muscles, and they were much strengthened. But above all else I was taught one thing of inestimable value, that "I am what every man is, grandeur" as the great Hungarian poet Ady wrote. I was taught there that my intrinsic value as a human being is not decreased with my decreased mobility, and that if they will it strongly enough, a disabled person can live in the world.

It is probably thanks to the time I spent in the Institute that I later had the willforce to finish Medical University, become qualified and establish a family.

Did the Petö Institute follow up on its patients? Did you have any connection with it later, or did you keep in touch because of becoming a doctor yourself?

As far as I am aware. The Institute later specialised in the treatment of patients with cerebral damage caused during birth, and other motor disorders are not now accepted for treatment. I was therefore never called back for a follow-up check, but I do know that the Institute followed up its patients regularly for many years. After finishing my studies I went back to the Institute to tell Dr. Hári (who had become director of the Institute in the meantime) that she had not wasted her time on me.

She simply took it for granted, and did not show any emotion, but one has to accept her as she is.

Another very important fact is that of the fourteen teenagers there during my time, eleven finished various degree courses. I don't know all of their names, but for example Attila Nagy became a psychologist, Judith an economist, Jules a painter and of course everyone know that András Pernye was one of our greatest musicologists.

\section{Does this mean that you are no longer in contact with each other?}

Yes, it does, but we are aware of each other, and we do meet occasionally. One of us was paralysed in both legs, but he worked on a machine that he rented from the Elzett Factory until 
he was fifty, and raised two children. He didn't go to university, but the necessity of working for a living was instilled in us at the Institute.

In my opinion Pető worked intuitively. When a person's disablement is due to a certain group of brain cells being damaged, another group of brain cells can learn or be taught to take over that function. That is how he was able to achieve such spectacular results with cases caused by cerebral haemorrhage during birth. Although nowadays even cases of cerebral haemorrhage occurring in adulthood are treated through conductive exercises at the Institute. A certain period of time was necessary before it became apparent that in the case of peripheral paralysis the cells of the spinal cord do not have the same potential ability as the brain cells. I'm sure that a neurologist could explain all this much better. But in the early days patients were not selected. Judging it from professional point of view I think that certain groups of disabilities have been dropped because they were not susceptible to this form of treatment.

I went to the Institute during that lucky period of one's life when one's personality becomes formed, between the ages of 14 and 18. They taught us to be both consistent and very particular. By very particular I mean that whatever we did, we did it as nearly perfectly as possible. So I cannot do any physical exercise haphazardly, but I have to do it as perfectly as I possibly can, no matter how many times I have to practise it. I learnt there that no matter how tired or fed up one is, one has to go on.

This must have been of great help to you in your medical studies and indeed in your life.

I can also trace the successes of my fellow patients to the same roots, since they also spent their formative teenage years at the Institute.

As far as Petö's recognition is concerned, I think that he was not really acknowledged in the beginning, but by the middle of the fifties a lot of people were interested in his work. There was a serious epidemic of infantile paralysis (Heine-Medin) in Hungary in 1951, and a lot of its victims were treated with us. This may have influenced recognition of his method. But that was not the only factor. He always achieved results. If nothing else then at least all those who were treated at the Institute left with improved gait - he developed such strong willpower in them. They managed to train the children out of many of their faults, or taught them to use their paralysed limbs to the maximum possible extent, because if someone didn't do their utmost, then they didn't eat that day.

You have told me that there was a flutist who was treated at the Institute whose arm was paralysed. But how could they motivate someone whose legs were paralysed?

I don't know of any special treatment that was used for them, apart from walking and movement exercises. The flute orchestra was a good way to relax a little.

The Institute was a place of great aspirations, and we were taught to have high aspirations as well. We were taken to the opera and theatre, and famous actors came to visit us. I consider this to be very important. Disabled children should be taught to love the arts from their earliest childhood, because that compensates for their lost abilities. My parents had me learn to play the piano, and when I was a teenager I was invited to all the parties to play the piano. At the time there were no tape-recorders and so I became the most important person among the children. This did wonders for my self-esteem, I did not become isolated and I had normal social relationships. I think that that was a fantastic thing. And I played away my sorrows on the piano with Chopin's ballads. I still go to concerts even now as this is an important way for me to preserve my poise. 


\section{ERIK SZAUDER ${ }^{215}$}

I was born in Budapest in 1967. I still live in Budapest, in Zugló, with my parents in a 50 $\mathrm{m}^{2}$ flat. I am a final year student of psychopedagogy at the Gusztáv Bárczi College of Special Education.

When my disability became apparent, we went to all kinds of different doctors, all of whom gave different, contradictory diagnoses. As a result of cerebral palsy caused by prenatal damage the tonicity of the extension and contraction muscles in my left leg changed. That's why I ended up in the Petô Institute's kindergarten, where I spent three years. Then a psychologist suggested that I should go to the Movement Development Elementary School, partly because of my disability, and partly because I had not reached the minimum weight above which I would be able to attend a normal elementary school. My parents didn't accept it, saying that I would not have received enough intellectual education there. They wanted me to go to a normal elementary school.

My father has an engineering degree, and is a head of department at Hungarian Television. My mother is a section head at the Sport Channel, and has an engineering diploma.

\section{So your parents didn't accept the Movement Development Elementary School?}

No, they did not. And luckily enough a normal elementary school nearby, in Erzsébet Királyné Road, accepted our application. I studied there for eight years. When I was in class seven I became interested in drama, and I discovered that one could study drama at the Imre Madách secondary school. I applied and was accepted there for a drama course. I knew that acting was not really the right profession for me, but I had some talent for direction. That was an exciting, positive period of my life, since as all teenage boys I had to come to terms with my changing a self-image and I could exorcise my problems by acting them out in plays.

\section{That is in fact the basis of psychodrama, isn't it?}

Yes, that's right. Although I am not sure about the part of psychodrama where there is a discussion. In a play there are a lot of inexplicable elements, and it's up to each person in the play where he or she brings out these effects. One can form an opinion much better through thinking them through quietly on ones own, than through talking about it, since there is an indescribable part of it, which cannot be put into words.

Although through a discussion one can get a method, a possibility, of how one might be able to express it.

\section{Do you remember what a typical day in the Petö kindergarten was like?}

It was a long time ago, but I'll try. We had sessions continuously.

\section{In a spirit of play?}

Yes, but sometimes we had to complete tasks, such as a motor disabled child would have to go and fetch his mug, and then get back to his place. It was up to us whether they did it with the aid of a chair, a stick or with the help of one of the other children. We were given tools to use, which helped. Self-reliance was very important, very much stressed. I don't have many concrete memories from my early childhood, I was wrapped up with myself and didn't take

\footnotetext{
${ }^{205}$ Erik Szauder (1967-2006) psychopedagogy
} 
much notice of my surroundings. The cerebral damage didn't harm my intellectual abilities, but there were some children in the kindergarten who were really brain-damaged. I could more or less read by the time I was four.

\section{Who gave you books, and what kind?}

Well, it started out with my being very interested in letters, I was always asking my father what this and that letter was, usually from a newspaper. Later I could recognise the letters on my own, and finally I reached the point where I could read sentences. What kind of books? Lots of children's books, but I could also read adult's books if I wanted to, I was allowed to take any book off the shelf. I could ask questions, but sometimes I didn't know what to ask. There was a book with a shiny green cover which was very confusing for me, and I couldn't understand a single word of it. I later found out that it was a little book by Pascal: Thoughts about Death.

\section{How old were you then?}

I think I was six. When I read, I withdrew very strongly into myself, it's still the same today. Subconsciously I try to exclude everybody and everything that has happened to me from my mind. In school it was a source of irritation to my classmates that I had already read many books which were unknown to them. On top of that I spent a lot of time in hospitals for checkups and operations, and death was a common topic of discussion on the wards. Sometimes someone would go for an operation, and then a few hours later a nurse would come, strip his bed and take all his belongings away, and we would all giggle. This all took place when I was twelve. I had the last operation on my leg in the third year of grammar school, when I was seventeen. When I left school I went to work as an assistant dramaturgist at a theatre. A year after that I applied to the psychodrama department at the College of Special Education. I am a final year student there now. In the meantime I completed a two year amateur directors course, which enables one to direct an amateur theatre company. My thesis is about the ways in which it would be possible to integrate drama into a Home for mentally disabled children education. I am already aware that a lot of the preconditions for making these institutions more liberal and freer are missing. Well, that's the story of my twenty-four years of life.

\section{May I ask you how you have come to terms with your condition?}

I'll try and answer. I have now got to the point that when a situation where I am brought face to face with my condition arises, and I realise that I am not going to be able to manage, that I just feel a little bitterness and also a little annoyance, but I now get over it relatively easily. It bothers me more if others remind me of it - even if its unintentionally - especially if I am judged differently from other people by others. It's a primitive example, but true that when young children who have not learnt to lie yet, even with their eyes, stare at me when I'm not too well then it disturbs me more. Or if adults, who have learnt to deal with such things in a sincere, socially-acceptable way, say things like "oh, you shouldn't do that, it's too difficult for you" then I can be just as bitter. In other words if they confront me with it from ostensibly humanitarian motives.

What do you mean "when you're not too well" - do you mean physically or emotionally?

I mainly mean my emotional condition. From the physical point of view there are days when I feel more tired and I'm not at the peak of physical fitness, but then everyone has days like that. Do you do anything to keep in shape? Or is it just that you should be doing something?

Well, I don't exercise as regularly as I should, but I do manage now and then. 
What does that mean? Exercising at home?

Yes, but I'm quite lazy in that respect and I don't usually spend as much time on my appearance as I should.

This is not a question of appearance, it's a matter of oiling the machine.

Yes, you're absolutely right.

And may we know what your emotional bad patches are caused by?

Nothing that everybody else isn't subject to. Tension from a particular task, or tiredness, or someone upsets me. But I usually bounce back quickly. I'm generally happy with myself.

\section{Could you form relationships easily at college?}

That's an interesting thing, because although I met my class mates relatively often, I didn't have a particularly good relationship with them, maybe because at first I was the only man in the group.

\section{How did you manage with the children during your teaching practice?}

Oh, I had to find out how to fit in with others a long time ago. Children are brutally honest, and the mentally disabled ask lots of questions. They would ask me if my leg hurt, and I told them that yes, it was diseased. They accepted it much quicker than an adult would, and the lesson would simply go on.

I can establish a rapport with children very quickly, possibly the drama studies helped. One of the children, who could have been five or six, suddenly rushed at me in a fit, which I didn't understand, but I didn't panic. I just bent down to him, lifted him up, held him in my arms and talked to him as if nothing had happened. I form a rapport quite easily, and I never have any problem distracting children's attention by an unexpected gesture from what they are doing and thus bringing them back into the lesson.

I'm told that my teaching style is quite original, since although I cover the curriculum we also cover a lot of other subjects during the lesson. For example in a grammar lesson we talked about India, and there was even Indian music in the background, but I connected it to grammar because we then had to parse the sentences which we had used. That is my way of trying to create a relaxed atmosphere in the classroom. Older children of 13 to 14 in the Home for mentally disabled children also accepted me, because I treated them as adults and not as children. I would listen to their problems. One of the best experiences was when a thirteen year old girl started telling me all about her most intimate secrets, about her relationships and about her family scandals, and all this after just a twenty minute acquaintance.

That sort of thing is very important. At the end of your studies, do you now know what you want to do with your life, where you want to go? Do you now feel that you are less restricted?

Of course. Many times I don't even consider things restrictions even though others may think or say that they are. I know that I can complete the things that I want to, maybe not by rushing around, but somehow I do manage. I walk a lot, but although others have often tried to persuade me to learn to drive, I do not want to shut myself into a little metal box. I am quite happy to go by bus or tram, even if there is a bit of a crowd. I have some of my best thoughts on trams.

Anyway, my limitations are much less than people think. My tutor once told me that the borderline between feeling pity for a mentally disabled person and feeling contempt for them is very thin, and I think the same is true for my disability as well. 
Do you think you could use psychodrama with disabled children?

Definitely. There is a very strange thing with mentally disabled children. They experience a lot of inner emotions and events, just in their case they are expressed differently: sometimes as aggression, sometimes in self-abuse. I think that even if not with psychodrama, not by analysis and feedback, still it is possible to find some ways or methods that can be used. Methods that can be given to the person in order that they can handle themselves and their environment a bit better. To reduce it to a very simple level, I could say that drama, theatre, is a tool for developing one's skills. If that is not appropriate for their development and education then I don't know what is. Mentally disabled children can sometimes come out with quite fantastic sentences. Once for example I was standing in the corridor with another student from college when we overheard a teacher shouting at a child: "What are you doing, boy, are you stupid?" and the child replied with wide-eyed innocence: "Of course I am, that's why I'm here." And then we both pondered the absurdity of the situation. I have also read poetry written by mentally disabled children.

\section{There should be an exhibition.}

I've seen a video about the work of disabled people, where all the arts were represented: music, sculpture, painting, all of which was put together into a dramatic whole. There are different workshops and groups where mentally disabled people act, prepare scenery and posters and so forth. There are mentally disabled adults, actually quite severely disabled with Downe's syndrome or even worse. And then there are animators, professional artists and university-trained musicians, architects and so forth, who provide training in the techniques, they show and tell how to do it, but what is produced is completely down to the individual. When it all comes together then once a year they put on a performance. They have performed in the Opera House in Liege, where they played their own music and put on a little play written by someone with Downe's Syndrome, in which one of the actors also suffered from Downe's Syndrome. Acting is about movement as well, so there was hard physical work involved as well. In Belgium, for example, Downe's Syndrome is not characterised by overweight and poor muscle tone, as it is described in Hungarian textbooks. Another example is an Italian private school where they bought horses, since riding is therapeutic.

\section{Did you study the Petö method?}

We only heard about it peripherally. I don't want to go into professional or political subjects.

\section{Why not?}

Because there is a strong conflict between the two institutions, the College and the Petö Institute, which started a long time ago and is, I think, because of personality clashes. The main difference between the two methods is that the College is trying to develop a homogenous special education. Namely that the so-called classic disability sufferers, the mentally disabled, the ones with hearing or speech disabilities, all of which has an immense body of literature and case studies, should receive homogenous treatment and guidance. So for example psychopedagogy, which is a completely separate subject, somehow became integrated into the treatment.

\section{So the College of Special Education is homogenous.}

Yes. But Petö and his Institute worked solely teaching how to live one's life, based upon the conductive education and movement development method. They mostly deal with cerebral injury and they didn't deal with any other disabilities, not even theoretically. 
What happens to the children who are brought up in the Petö kindergarten after they finish school, them? Are they just scattered to the four winds? What are their roots? They have been removed from their family background, so where can they go to?

What do the adult motor disabled do? Well, there are associations, they must provide some sort of protection.

I wasn't thinking about people who live in institutions. Speech, hearing and sight impaired adults, for example, have very well-organised associations.

They might have, I don't know, since I have never felt the need to look for them. By the way those who spent a longer period of time at the Petö Institute are followed up, they have a good after-care unit. But of course that doesn't have much effect on motor disabled people in Hungary, since not so many of them were treated at the Petô Institute.

There is absolutely no connection between the College and the Petö Institute. To such an extent that if someone who graduates from the College wants to go and work at the Institute, because they want to complete their knowledge by learning the Petó method, they are told to use their college degree and knowledge to help the disabled, but they are not accepted to the Institute.

And yet it is the patients who are important, not power and politics. Perhaps one day the conflict will cease. 



\section{DR JÚLIA DÉVAl'}

I met András Pető in November 1946. I was taken to his home on the Stollár Béla Street by János Werkner, with whom I used to attend the same class at the univesity. He was a former polio patient and a devoted admirer of Petö.

The home belonged to the Family Bródy, Erzsi Bródy shared not only their home and food with Petö, but she also helped with his first treatments. (A few years later she was accused by the communists with an unbelievable and unrealistic spy story, and she was imprisoned. After her release she left the country with her husband for Israel, where she died at an old age.)

On that grey November day Pető was sitting behind his desk, leaning back on his chair. His eyes were only partly open, but, while talking to somebody, he seemed to be aware of everything that was going on. He did not even look at us, only indicated the door to the next room with his head.

I was eager to leave the place where nobody paid any attention to me, and happily entered the next room. There were three people inside doing different things. One of them was lying on the floor, and tried to reach the end of the carpet with his extended legs and feet. The other was sitting on a chair, attempting to lift a seemingly paralyzed arm with the good one, and the third person was leaning on a chair, while bending and extending a knee along the leg of the chair. There was a slight murmur in the room, because everybody was counting slowly, according to the rhythm of the forced moves. The murmur, the quiet effort and the unbelievable concentration of these people created such a great tension the the room, that there was no space left for questions. I was simply drawn into their world, and before long I realized that I was unconsciously counting and sitting on one of the chairs to help to stabilize it. I wanted them to succeed, I wanted that knee to bend and that arm to raise with such a fervor, that I hardly realized the Patö was standing in the middle of the room. He walked to every one of them, showed a better grip, turned something here, pushed a little bit there. The guy using the new trick Petö just showed him, was finally lifting his arm, and was all smiled, without interrupting our counting.

Pető had a sturdy, massive, not too tall body, with broad shoulders, and a round, shining bald head. Especially while sitting, he gave the peculiar impression of a Buddha statue. When he saw me sitting on the chair enthusiastically counting, he smiled once more, and with a royal gesture he gave me permission to come again. The next day I was told by Werkner that this was the greatest possible praise anybody could ever get from Petö. From then on I was frequent visitor in his apartment.

At the beginning Pető almost never talked to me. I heard his life story only from my friend, János Werker and Petô's voluntary landlady Erzsi Bródy. Pető was said to have escaped from Vienna because of Hitler. He was born in Szombathely, which is a lively town on the Western border of Hungary. Because the town was located closer to Vienna than to Budapest, he attended the University of Vienna. After working several years he became the head of one of the department of a big pulmonolgy hospital, where he was involved in working with different chronic patients. In Hungary he had to work somewhat illegally, because he did not have a licence till the end of the war. Despite his unaccepted Austrian certificate, he kept working, but never accepted money for his work. He was living mostly on money offered to him by his friends, who took it as a personal honour, just like the Family Bródy felt privileged to offer

\footnotetext{
${ }^{206}$ Dr Júlia Dévai (1913-2015), Cief radiologyst: The first years with András Petö: The birth of conductive education. OMOD 1997. Budapest pp.1-8.
} 
their home to Pető. In his later years he still maintained a special relationship with finances. He kept his personal needs to a minimum. When at least he had a salary as the director of his institution and as a college professor, his whole income was divided among his friends and/or their families in need. It had become the Institute's later director Marika Hári's task to take care of the distribution of the money.

At that time only half of his patients suffered motor problems, the other half or even more had internal or dermatologic diseases. His methods were somewhat unusual in Hungary, and could not be easily adapted to any traditional hospital setting. He was convinced that the essence of the "movement therapy", which was the original name of conductive education, was a learning process, thus it seemed logical to get this new discipline accepted through the Ministry of Education, especially as he had a few friends there who could pull some strings. In spite of this process was long and tiring, and full of unnecessary bureaucratic procedures which he did not intend to spend his time with.

Instead of him, a group of his devoted students and many friends took care of the organization according to his strict instructions. As the "delegate of the impatient students", I was also sent several times to certain high ranking officials to the Ministry, expressing an urgent wish to study and apply the new method.

At this time Pető's students were his co-workers as well. We were all recruited by János Werker from the second class of the Medical University of Budapest. After about two-three months of listening to our excited discussion of our important and real work with this fantastic man in a fantastic world of effort, pain and wonders, Marika Hári also wanted to belong to this privileged group. We could get her in only after some difficulties, but at the end her endless devotion, her frugal needs and unbelievable persistence got her a speical positon with Pető.

As a result of our persistence in facing and fighting the earlier mentioned bureaucratic difficulties, in 1947 Petö finally got a not too big place in one of the old buldings of the Teachers' Training College for Special Education, and at last he could start to think about moving his treatment center from the Stollár Béla Street to a move appropriate place. At that time the director of the college was Professor Gusztáv Bárczi, a broad minded intellect of his time. He wanted to adopt the Pető method as a part of special education, which suited Pető fine on one side, but on the other side he did not wish to become part of any established field. Thus their relationship was not one without every distraction.

The place Petô got consisted of four rooms on a broad corridor, and a small cubicle under the stairs. After acquiring two lab stands, one small alcohol burner and four bottles of chemicals, the cubicle was referred to as "the lab", where the later director Marika Hári's career has started. Beside the "lab", there were two dorms, a big treatment room, and one office for Peto".

Since Petö got only the empty rooms, we all worked hard in getting together at least some meager furniture. The war was hardly two years past and supplies were scarce. Hearsay was the only source for finding the necessary furnishings. A friend knew about an abandoned store room where one could find a few hospital beds with black iron springs. Another brought news about some old mattresses in a cellar. A Swiss trade union called CGT donated one pillow and two grey soldiers' blankets per bed, and they also gave some bed sheets, pyjamas, and diapers. (The head of organization in Hungary at that time was a certain Toni Drittenbass, who was later imprisoned by the communists as a spy, and she gave birth to her baby in a Hungarian prison.) Shoes, socks, and underwear were offered by the Red Cross.

The whole bathroom consisted of one small basin, one tin bathtub and one cylindrical water heater using lots of wood for a small amount of water. The equipment was donated by one of 
our classmates from the university, who was working in his own tinshop to support himself through the university years. We used the tub not only for bathing the kids, but, with some modification it also served as our dishwasher facility. In the treatment room we had three berths, put together by a concentration camp survivor carpenter. Because of the general postwar poverty, the carpenter had only fragments of timber, broken logs and boards, thus he could not make a bench with a nice smooth surface. He created something called "pricks". It was the prototype of what is the obligatory Petö bed today. He said he got idea from the concentration camp, and, he added with good hearted self irony, if these berths were good enough for the prisoners, they would surely be OK for some young crips...

We wanted Petö to have a decent office, so we went to a fleamarket on the other side of the city. We bought him a desk, a chair, and even a beautiful Persian rug. As it turned out later, the original motif of the old carpet was only painted on a mat. He had Van Gogh's reproductions on his walls, probably still missing from somebody's album.

We also had to think about some chlothes for the future patients, thus my husband, who had good connections with the storage manager of a big textile factory, got two huge bales of red and blue checkered cotton, with some printing errors in them. Mr. Bárczi knew about a sheltered workshop, where people with intellectual disabilities were sewing. The garments they produced were definitely not haute couture, but it surely determined the style, the colour, and the cut of the clothing that could be worn in the Petö Institute for many years to come.

The whole operation was directed by Petö sitting at the table in the Café Elysée. It was his general headquarter, where he received his friends, admirers, and students, sometimes as their host, at other times as their guest. He liked good food, good cigars, and spirited talks about the latest news of the literary world, about arts and politics or scientific events. He made his plans there, with detailed notes about everything, carefully dispatching, delegating, and controlling every single task. It never happened that he assigned something and forgot about it. No. You could be sure that once he told you to do something, he would get back to you and ask about the result. We never knew why, and never questioned either each other, or ourselves why we were so eager to help, to accomplish, to contribute, with no salary, no money whatsoever, no great career possibilities either. It must have been just his belief, his total commitment that infected us. During this whole period he never ceased to see his regular patients, and if he had no time to visit them in their homes, there were always some of us to proudly volunteer.

By Christmas of 1947, everything was ready for us to take in the first inpatients. We thought it would be easy to find kids in need of this new kind of motor training. But the opposition on the part of the medical society was strong. The orthopedic surgeons resented that Petö's method lacked both surgical solutions and the use of technical support aids. Neurologists did not believe in any form of therapy for cerebral paretic children. Thus all Petö could get was a group of thirteen kids from the neurologic department of an orphanage (today it is the Heim Pál Children's Hospital), all of them in severe condition: athetotic, spastic, hypotonic, quadriplegic, hydrocephalic and spine bifida patients, and a few polio stricken kids between ages six and twelve. One of the department heads of the orphanage could not suppress a demeaning and somewhat ironic smile while he assigned the most hopeless cases to Petö: if he is really so big with his new fancy method, he should demonstrate it on these kids!

We were standing shocked and numb in the huge ward. The kids were lying in crib like beds, with almost no clothes, only turning their heads back and forth, making monotone noises. They were undernourished, dirty, and sad. We hired two cabs, covered the kids in blankets, and took them to our new place, where everything smelled of fresh paint. We bathed them, gave 
them new, clean pyjamas and fed them. The food was brought from a nearby kitchen for the mentally retarded kids. For two years it was a basic diet. Whatever was available on the empty, postwar market served as their food in contrast with any dietary need: dried peas, beans, cabbage, grit. We had milk and bread too, and sometimes we got cheese or a piece of bologna. We almost never had meat. Pető presribed certain vitamin sources to add, like sour cabbage, codliver oil, yeast and carrots. Later in the Spring we could get some vegatables and sometimes fruits too. The kids felt they were in heaven: they were clean, and warm, and well fed. Small details never disturbed them, like we never had enough chairs, and the tables on the corridor served for dining, writing, learning, playing, and everythings else. But we had paintings from Piroska Szántó, and other original pieces of art, donated by Petö's friends, making the whole, basically dreary place somewhat more humane. Petö wanted more than that the kids should just feel happy and at home, he wanted something to happen to them as soon as possible.

At the very beginning one of our biggest problems was that Petö got no helping personnel from the college, except a maintenance person and a guy who worked in the basement with the coal stoves. There was an older lady, a retired teacher, who was paid as a caretaker, but when the first night came, it turned out that she also wanted to go home, as all of us, the five volunteer medical students did. We just looked at each other, and it seemed that Petô himself would have to spend the first night with the kids, but at the end the old lady, Ilonka stayed.

There was an urgent need to hire helpers or "treaters", as they were called at that time. By a lucky coincidence a friend of Pető sent a few girls to him, who came to Budapest after the war from small villages to look for jobs. Justina, Agnes, Iren were the first girls, later Ili joined them. Her six month old baby at that time has since become the present Institute Director.

At the beginning these uneducated girls provided all the support and care the kids needed. They ate with the kids, they slept in the same room, they sang and played together. The girls had no home outside his small place, kids and caretakers all shared the same life. Petö was instructing not only us, but these girls as well. They were the forerunners of the sophisticated conductors of later days, who would be required to have a high school graduation, a successful entrance exam before they could even think about setting foot into the Petö Institute. But at the beginning all Pető wanted was a good, absorbing head, a good, attentive heart, and lots of committed hard work.

Pető closely observed every child, and based on these observations, he compiled individual series of exercies. He regularly controlled, corrected, and improved these series. Originally, there were two individual, one hour long sessions daily, and it happened only later that during individual sessions work began in groups. His attitude toward the kids was a kind of strong suggestion: I know you can do that! He spent hours with the kids experimenting with new solutions, new tasks. He was very open minded, and was always ready to refine his method. $\mathrm{He}$ demonstrated everything with his own body, quietly counting or rhythmically telling the text to enhance the concentration. He kept his eyes closed, but there was no tiny detail escaping his vision. The strength of his personality was tremendous. The kids simply got attached to him, and tried to do their best only to please him. We did the same, and tried not to miss any of his sentences, murmurs, or moves. We wrote down his first series of exercises, and tried to repeat them with the kids exactly the same way he did. There were no written textbooks on conductive education, because there was no conductive education. It was born and created in front of us. The first written form was a twenty page long workbook for special education students, put together by Pető and myself.

As the time went by, more and more families turned up with their physically disabled children, because it was the only place in the country where something effective was happening to them. In many cases the family members also got interested and involved in the 
work, thus more and more individual and troup sessions could be provided. During this period, the typical Pető schedule of the days was formed: exercises, sing along, meals, rest, later learning and play filled the days in the regular rhythm and everything became part of the whole treatment. The intensity of this program brought early results in these previously never treated children. Even experts from abroad paid attention to these unexpected results.

This was the beginning. After two years the need became so great that we had to move to a brand new building, where a new era started. This new era has already been frequently narrated and described by others, thus I wish to add only a few personal remarks to the story of the first two years spent with Petö.

Even though I was, and still am, truly devoted to Pető, beside recognizing his significance, I realize that he had some peculiar features.

For example, he did not like people with too much independent opinion, but he did not appreciate dullness either. He wanted to be well informed about everything that was going on in his absence, so needed absolutely devoted, biased "ears" around. He never cared whether we had time or not, whether we could skip classes at the university, or how our families related to our spending so much time at the Institute (at that time I had a two year old daughter and an infant at home!). It is not that he was not interested in our lives, oh no, he wanted to know everthing about us. It is just that he had this strange sense of time: you had to spend twenty hours with the kids, four hours with reading and administration, but afterwards you were free to do whatever you wanted with the remaining hours.

If his instructions were not followed accurately, if some "improvisation" happened as he put it, he became extremely upset. He flushed, yelled, shook his fist, pushed the sinner out of the door. But as quickly as he lost his temper, he soon forgot about it. He smiled, gave a kiss on the forehead, offered a book or a nice poem. Other than this smile, which was his only form of rare praise, one had to offer lots of hard work, with excellent results, no matter whether it was a child or one of us. Because of his great charisma, the magnetism of his personality, we not only worked hard, but we also enjoyed it.

Beside creating his original method, and for this procedure using all the available therapeutic possibilities, Pető was a polyhistor, a person of many talents. He was interested in philosophy, contemporary math and physics, and had a vast knowledge of literature. More than that, he was an excellent poet, and an author of dramas portraying a Dürrenmatt type world. If he cared enough, he probably would have become a well known author, but only his closes friends knew about and appreciated this side of his talent. In his wide circle of friends there were mainly writers, poets, and artists. His best friend from his early youth was Jakob Levi Moreno, the father of psychodrama. Zerka Moreno, the widow of Levi Moreno remembers Petô as a gallant, friendly, good humoured guy, who had abundant lady friends, and was extremely well read. He liked his family very much, especially his mother. He never got married.

Despite the fact that I belonged to his immediate co-workers only till 1952, we maintained a very close, regular, weekly relationship until his death in 1967 . The time I could spend with him definitely determined my whole career, my medical thinking, and moral behavior. Till today, thirty years later, his death is still a great loss to me. 



\section{Dr Mária Hári ${ }^{207}$}

\section{Who was András Pető? ${ }^{208}$}

One article by a noted writer entitled: 'The man who cannot be put into words.' András Pető was a great Hungarian educator and doctor who created the system of conductive education. His life, his work and his creativity were all directed towards progress. The Conductive Education system which he established had a significant influence on ideas about rehabilitation. He was far in advance of his time in the areas of integration and normalisation and showed the way for humanist rehabilitation.

He opened up the thinking in which placing people in society, rather than segregating them, is considered most important. Petö was the first to regard handicap as an educational problem.

...His contemporaries' reactions were mixed. Some turned towards him, some away from him - his work was acknowledgeed in his lifetime.

...His name is used as a trade mark in various places, and we have not demanded should in that case be used correctly.

...He endured the opposition through his moral strength and will power. What J.Wigner said also applies to Pető's life work: 'Raising something from zero to one is more significant than raising it from one to live.'

${ }^{207}$ Dr Mária Hári the first director (1967-1993) after Pető's death int he International Pető Institute in Budapest

${ }^{208}$ Petö Magazine, Summer, 1966 pp. 5-8 

1. Ákos K. and Ákos :, The enigmatic Dr Pető, The Conductor, 6, nos.3-4, 1997

2. Ákos, K. and Ákos, M.: Dina. A mother practices Conductive Education. Birmingham and Lm, 1991

3. Arieh Ben- Tov: Holocaust. Budapest. Dunakönyv. 1992.

4. Bárczi G: Magyar Orvosi Szemle 25th February 1948

5. Biró K. (1993) Remembering András Pető. In: Pető András (1893-1993) Pető Conductive Education International Institute. - Kozma Gy.-né : Budapest,1994.

6. Braham R.: Hungarian Holocaust. Budapest. Gondolat. 1988.

7. Cottam Ph, A. Sutton (eds.) Conductive Education, London, Croom Helm, 1985,

8. Cotton, E. - Pamwell, M.: From Hungary the Pető method. British Joumal of Special Education. 56., 4, 7-11. 1967.

9. Cotton, E.: The institute for movement therapy and school for conductors, Budapest, Hungary: A report on a study visit. Developmental Medicine Child Neurology. 1965. 7., 4.

10. Curriculum vitae of András Petö, in a glass display cabinet at the International Pető Institute, Budapest.

11. Dévai J.: The first years with András Pető: The birth of conductive education. OMOD 1997. Budapest

12. First World Congress [on Conductive Education], 29 November -1 December, Budapest, Hungary : Conference Proceedings 1. The Intemational Petö Association. 1990,

13. Forster V: A view from the past, The Conductor, 6, nos, 3-4, 1997

14. Gát F.: Remembering the decades of domestic children's and youth welfare after the liberation. Gyermek és ifjúság védelem Vol. I. 1986

15. Gordos A. Szabó: The history of special education, Budapest, 1988. Tankönyvkiadó.

16. Hanák P.: Reflections about Viennese and Budapest culture at the turn of the Century. In $A$ Kert és Budapest, Gondolat. 1988.

17. Hári M.- Ákos K: Conductive Education. London; New York : Routledge, 1988.

18. Hári M. (ed.): Pető András (1893-1993), Budapest, Pető Institute, 1993

19. Hári M.-Székely F.-né: Konduktiv pedagógia. Köznevelés, 1968. 24, 13-14;

20. Hári M.: The history of conductive education and its concepts. First World Conference of Conductive Education MPANNI. 1990

21. Hári M.: The history of Conductive Education, Budapest, MPANNI. 1997

22. Horváth J.: András Pető - A brief biographical sketch. Occasional Papers. No 1 p 2.1997

23. Hungarian Gazette No 89. 21st December 1963: The Hungarian Workers' and Peasants' Government Decree, 21.12.1963/36

24. K. O. Bärnklau: [A. Petö], Unfug der Krankheit - Triumph der Heilkunst, Hanau/Main, Verlag Karl Schuster, 1965

25. Kozma I.: The special content, quality and structure of the conductor training. First World Congress on Conductive Education. Budapest MPANNI. 1990.

26. Kozma, I.: The past, the present and the future of the Petö system. School for Parents Network, 2nd National Conference, Repton, Berby UK. 24 March. Presented at The Spastic's Society. 1994

27. Law Reports 30th December 1963. Volume 13. Number 15. 2031/30.12.1963

28. Medve L.: Report on the circumstances of the Pető Institute. Budapest, 16th June, 1986.

29. Németh A: A szélén behajtva, p 594 Budapest. Magvető. 1973. 
30. Palotás G.: Dr Gusztáv Bárczi. Orvosi Hetilap. Volume 133. Issue 14.1992.

31. Petö A.: A note on the subject of neurocare (translated into English), The Conductor, 6, no. 1, 1995

32. Pető A.: Conductive movement therapy as special education (translated into English and edited), The Conductor, 5, no.2, 1993

33. Pető A.: Conductive movement therapy as special education. In Gyógypedagógia, Vol. I. Jan.-April 1955

34. Sárkány J.: Memories of Dr András Pető, The Conductor 6, nos. 3-4, 1995

35. Sutton A.: Conductive Education and cognitive education, Paper presented at the Seventh Biennial Conference of the International Association of Cognitive Education, University of Calgary, June 1999

36. Sutton A.: What's in a name? The Conductor, 5, nos.3-4, 1997

37. Vas I.: Why does the bearded vulture scream? Bp. Szépirodalmi Publishers. 1981

38. Vekerdy T: Álmok és lidércek, Budapest, T-Twins. 1992.

39. Vértes O. J.: A magyar gyógyító pedagógia 1848-ban és ma In A köznevelés évkönyve ed. by Á. Kiss. Budapest. MVKM. 1948.

40. Yearbook of Statistics 1949-1955. Budapest, KSH. 1957

41. Zsebők Z.: Lépcsőfokok, Budapest. Szépirodalmi Könyvkiadó. 1981. 


\section{Index}

A

abandoned and socially dificult children 15 Károly Ákos 17, 43, 48, 49, 55, 61, 75, 82, 88,115

Alexits György 85,

Andics Erzsébet 86, 88

Adrian, Edgar Douglas 25

Andry, Nicolas 15

Anschluss 27

anti-Semitic laws 28

Arrow-Cross Party 29

Aschner, Bernard 27

athetosis 18

B

Bárczi Gusztáv 31, 32, 33, 34, 35, 54, 68, $89,107,114,115,121,125,128,129$, $137,144,145,151,152$

Békésy György 31, 114

Bernáth Aurél 83

Biologische Heilkunst 27

Biszku BéIa 13, 37, 51, 54, 55, 56, 59, 60, $97,119,125,127,128$,

black boksz 17

blind 15, 32, 37, 54, 114, 1528

Boerhave, Herman 15

Bródy family 62, 80, 99, 103, 143

C

Cajal, Ramon 25

cerebral damage 20,69, 135, 188, cerebral palsy $33,36,117,137$, child nurses 17

College of Special Educalion 32, 43, 54, 61, $79,82,102,125,128,129,137,138,140$

Comenius, Jan Amos 15

conductive education $15,17,25,27,33$, 49, 52, 54, 71, 90, 103, 105, 116, 117, $118,127,140,143,144,146,149,151$ conductive pedagogy $9,10,11,12,13,17$, $18,19,20,36,55,56,57,63,69,70,71$, conductor $9,11,13,17,20,32,36,45,51,68$, $69,75,82,89,91,93,105,113,115,117$, $125,131,135,146$,
D

deaf 15

Déry Tibor 63

Dévai Júlia 34, 54, 62, 63, 143, 151

disabled children $15,16,39,45,60,70,82$, $121,128,131,136,138,139,140,146$,

Dobszay László 32, 81

Doleschall Frigyes dr 57

Donáth Tibor 75

dumb 15

dysfunction 17

É

Ehrenstein Angela 26

F

facilitated 17, 90,

Ferencz Győző 43, 90

Focher László 32, 44

Frank Johann Peter 15

Freud Sigmund 24

Frim Jakab 31

G

Gegesi Kiss Pál 11, 13, 51, 52, 93, 95, 102, 115,123 ,

Gelléri Andor Endre 27

Gestalt psychology 25

Golgi, Camillo 25

Gönczi László 61, 73, 79, 80

Good Shepherd Committee 28

Gráber Hédi 88

Grinzing 26

Guggenbuhl, Hans Jacob 16

$\mathrm{H}$

handicapped children 17, 34, 37

Hári Mária 9, 25, 35, 48, 53, 54, 60, 62, $65,69,74,82,86,88,91,100,105$, $113,115,119,120,122,125,128,135$, 144,149

healing 11,13

healing education $16,17,91$, 
Hecht 26

Heine-Medin 21, 41, 43, 48, 51, 55, 82, 90, $94,107,114,116,125,136$,

Hermann Imre 66, 104

Hideg Pál 44, 90

Hidvégi Katalin 45, 60

Hill Archibald Vivian 26

Holzinger dr 27

Horváth László 13, 20, 47, 48, 53, 60, 73, 126

Hull Clark 26

Hungarian health matters 15

'hyperkinetic' movements 18

I

Ilku Pál 27, 57, 123

Itard Jean Gaspard Marie 15

$\mathrm{J}$

Jewish Laws 28

JOINT 28, 33, 80

K

Kádár János 70

Karácsony Sándor 17

Károlyi Mihály 32

Károlyi Mihályné (Andrássy Katinka) 81

Kassák Lajos 24, 87, 94

Kemény Gábor 38

Kenyeres Imréné Ágnes 29, 38, 43, 53, 83, 88

Keresztúry Dezső 38, 85

Kiss Fercnc 101, 102

Kodály schools 16

Kolos Tamás 103

Komoly Ottó 28, 29, 80

Kontra György 17

Kozmucza Flóra 79, 96,

Krizen 26

Kun Miklós 21, 27, 28, 29, 31, 32, 61, 74, $81,84,96,99,102,107,108,129$,

$\mathrm{L}$

László Pá1 44, 90

Liebermann Lucy 32, 51, 93, 96, 102, $\mathrm{M}$

Madzsar Alice 31
Mándi Iván 88

Mándy Marianna 83

Mauer 26

Mérei Ferenc 61, 79

mental disability 15,125

mentally disabled 16, 31, 54, 89, 114, 121, $125,128,131,138,139,140$

Meyerhof, Otto 25

Mihály Ottó 17

Mihályi Gábor and Mariann 88

Moreno Jacob Levy 25, 63, 73, 81, 117, 118, 123, 147,

motor disabled patients 82

motor disorder 5, 9, 13, 15, 17, 18, 19, 20, $23,29,32,33,41,45,52,53,56,69$, $86,90,93,94,95,96,113,127,135$

motor-dysfunctional 17

movement 17

movement system 94

movement therapy $6,9,11,13,17,26,29$, $32,33,39,51,55,60,61,63,80,85$, $91,101,107,109,113,114,125,127$, 129,144 ,

Movement Theapy Department 32, 43, Movement Therapy Institute 42, 43, 47, $56,68,102,121,134,151$,

multiple sclerosis 20, 80, 82, 83, 128

music 16, 23, 47, 66, 90, 110, 134, 139, 140

Musil, Robert 23

$\mathrm{N}$

Németh Andor 24, 27, 63, 64, 115

Népszabadság 37

neuro-pathology 15,82

$\mathrm{O}$

orthofunction 11

Ortutay Gyula 13, 38, 39, 43, 51, 53, 85, $86,97,123,127$

$\mathrm{P}$

Palotás Gábor 31, 33, 41, 47, 48, 61, 62, $101,102,106,107,110,113,115,126$, 152

Pán Imre 87, 88, 99, 108

Pándy Imre 88 
Paris 6, 15, 27, 28, 79, 108,

Parkinson disease 117

Pavlov, Ivan 12, 24, 25, 27, 51, 94, 129,

Pesta László 57, 91, 92

Pester Lloyd 6, 23, 87, 109

physiological learning method 16

physiotherapy $6,31,33,45,82,131$

Pók Lajos 79

Popper Péter 10, 23, 29, 64, 66, 74, 99, 103, 110, 127,

pseudonyms 27

psychodrama 25, 63, 119, 137, 138, 140, 147 ,

$\mathrm{R}$

Radnót Magda 83, 88

Radnóti Miklós 28, 38, 73, 79, 80, 85

Radnóti Miklósné Fifi 39, 85, 88

Rákosi Mátyás 12, 34, 89

Ratio Educationis 15

Ratkó Anna 32, 43, 81, 95,

Red Cross 28, 29, 35, 57, 80, 96, 107, 144

rhythm 15, 16, 37,62, 143

S

Seguin Edouard 16

self-healing 73

Semmering Institute 26

Sherrington Charles Scott 25

Simonovits István 38, 54, 55, 85, 116, 122

Schlachta Margit 29, 80

State Home for Destitute Children

Stegreiff Theatre (Theatre of Improvisation) 32, 44, 90

Steiner Rudolf 16, 74

Steinhof 26

stroke 54, 117, 125

Sulyomi Schulmann Adolf 32

Swieten, Gerhard van 15

Szamosi Károly 37, 38, 119, 122, 123

Szántó Piroska 36, 146

Szauder Erik 69, 137
Székely Ilona 10, 17, 20, 26, 33, 34, 43, 54, 55, 57, 59, 74, 88, 89, 105, 119, $120,121,127$,

Szentágothai János 11, 52, 75, 120

Szentpál Olga 53, 63, 86

Szombathely 23, 70, 87, 109, 123, 143

Szondi Lipót 32, 61, 79, 82, 96

Szurdi boys 88

\section{$\mathrm{T}$}

Teacher Training College fof Special Education 43, 56

Teachers' Training College for Functional Exercises 31

Tomcsik Miklós 14, 49

Török Béla 31, 114

Török Sándor 17, 56, 88, 99, 109, 115

V

Vas István 63, 64

Vekerdy Tamás 17, 41, 56, 64, 74, 152

Vienna 6, 23, 24, 25, 26, 27, 42, 59, 64, $79,81,83,86,87,109,117,123,126$, 143 ,

Viennese medical school 74

W

Wagner Jaugger 25, 26

Waldorf School 16

Werkner János 34, 62, 115, 143

Wundt Wilhelm 25

\section{Z}

Zionist Movement 28

Zsebök Zoltán 39, 43, 85

Zsolt Béla 28 


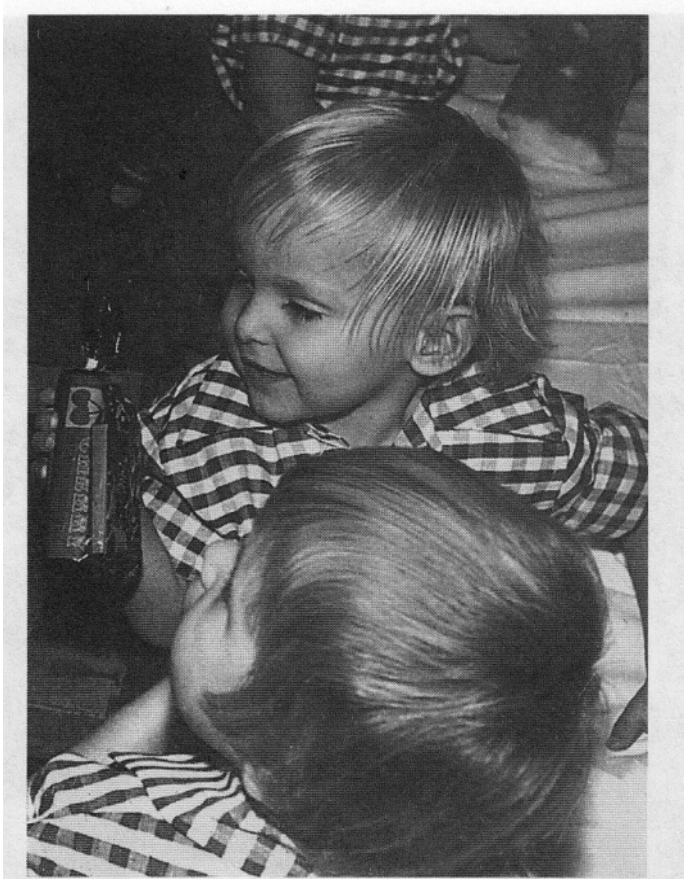

1. The youngers

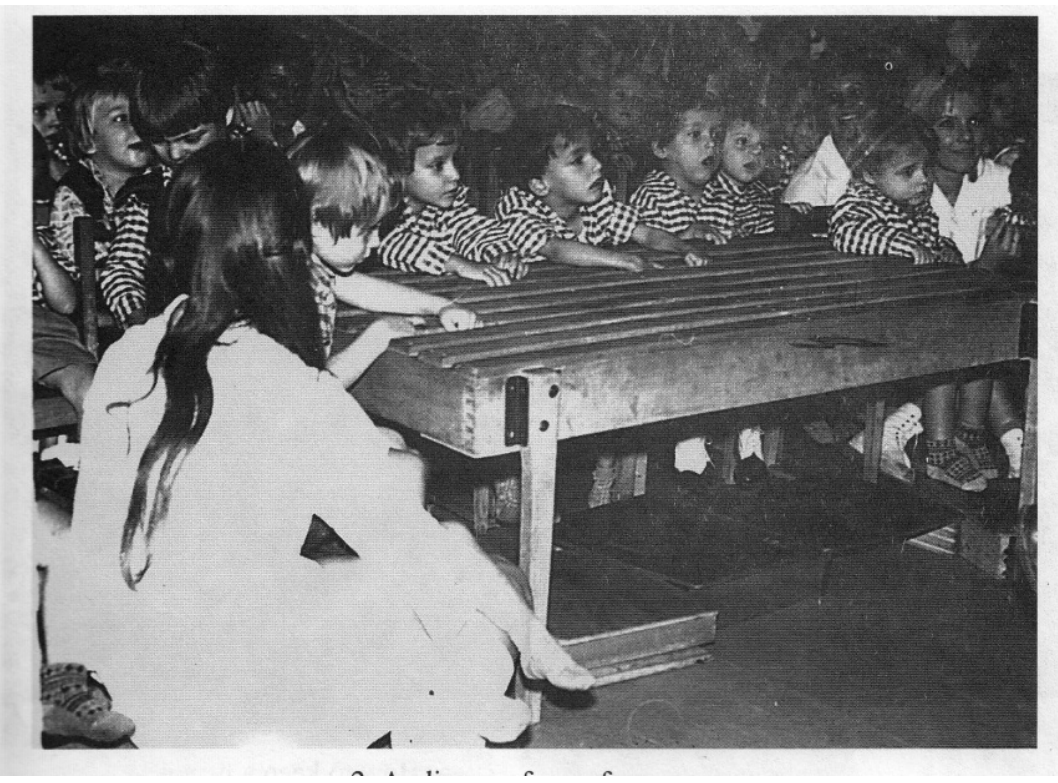

2. Audience of a performance 


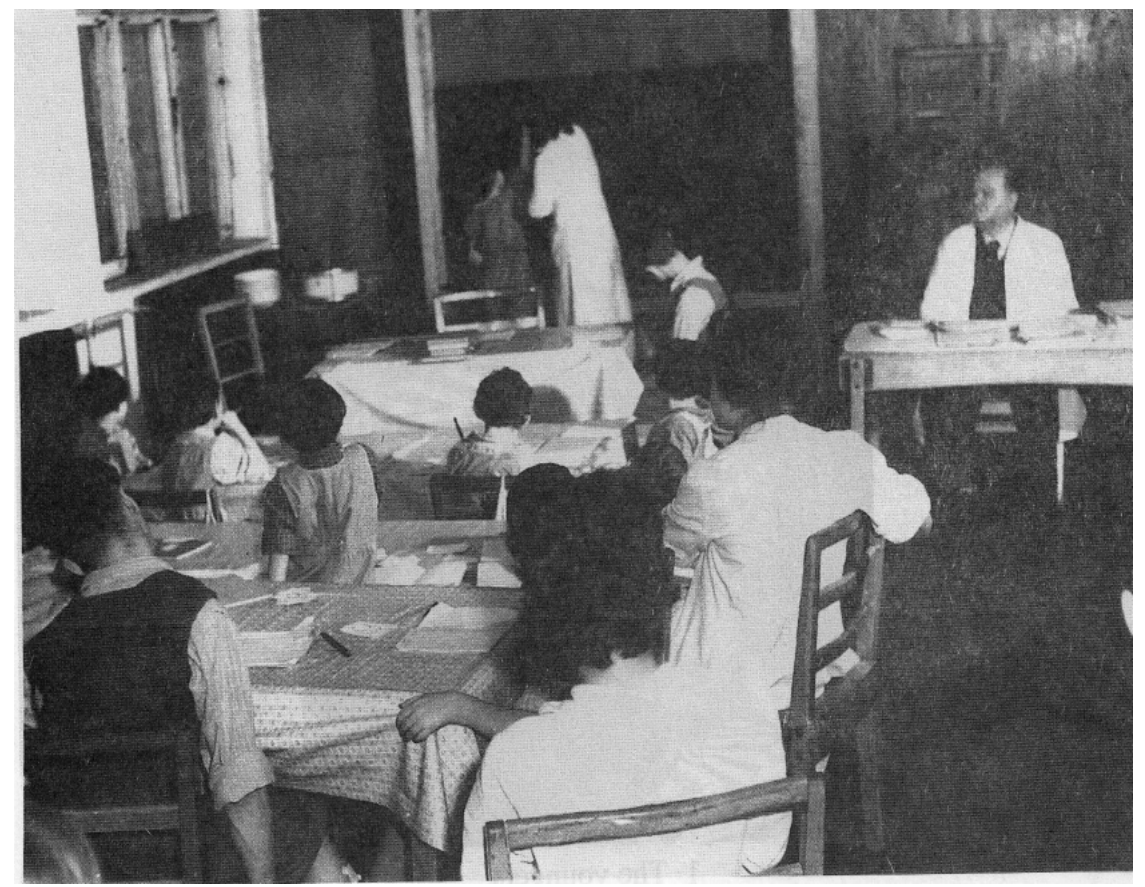

3. School hours
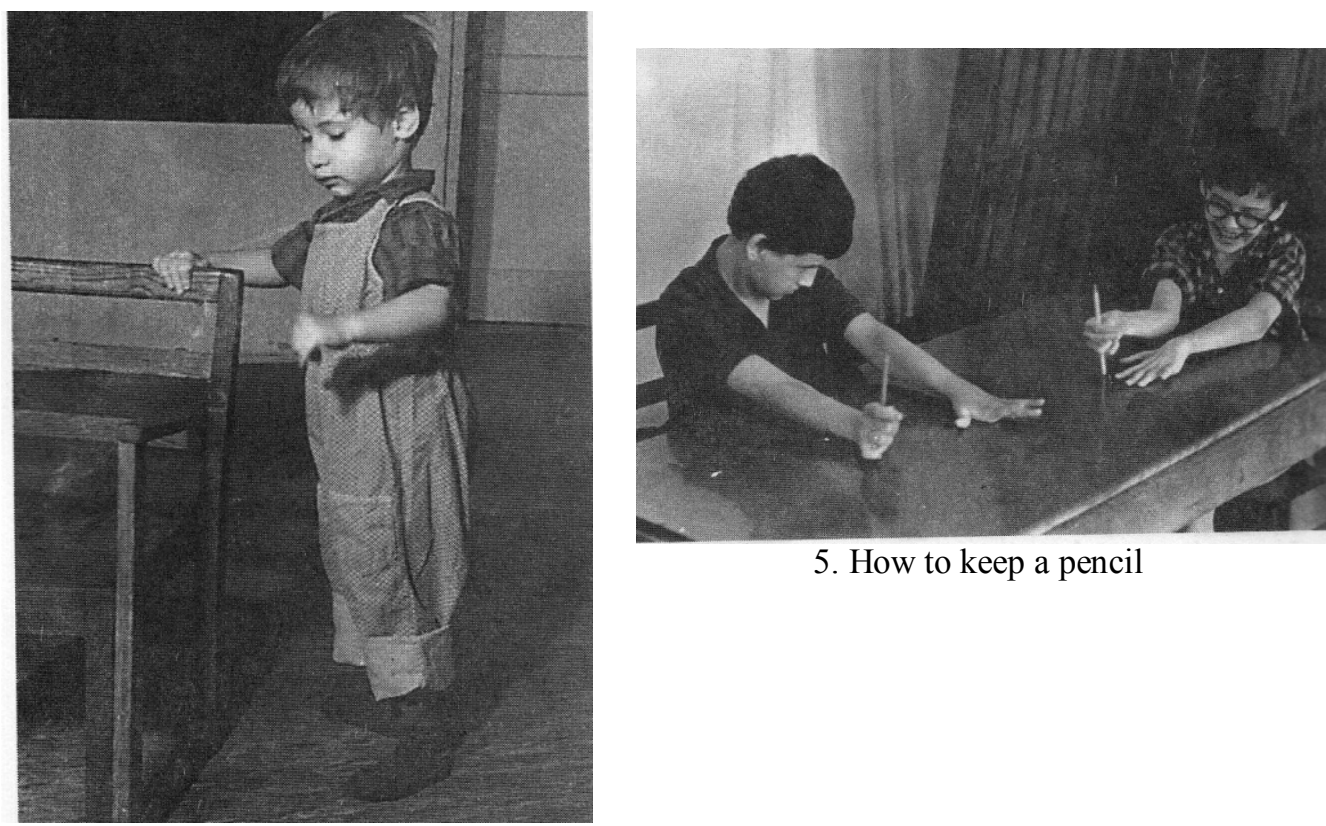

5. How to keep a pencil

4. Foot excercise 


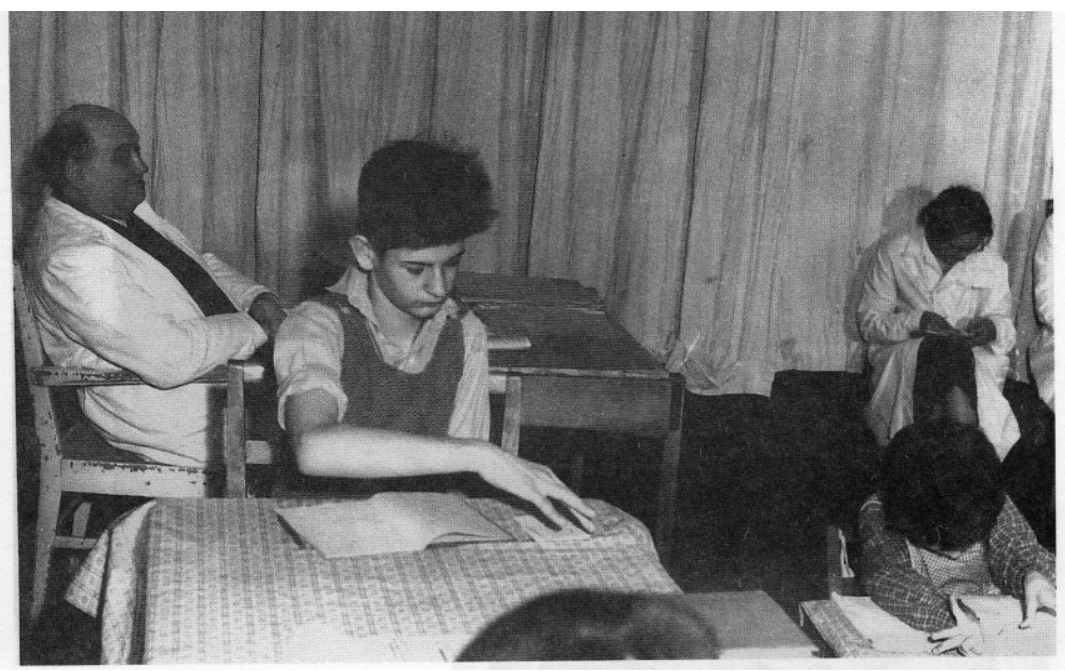

6. Hand ecercise

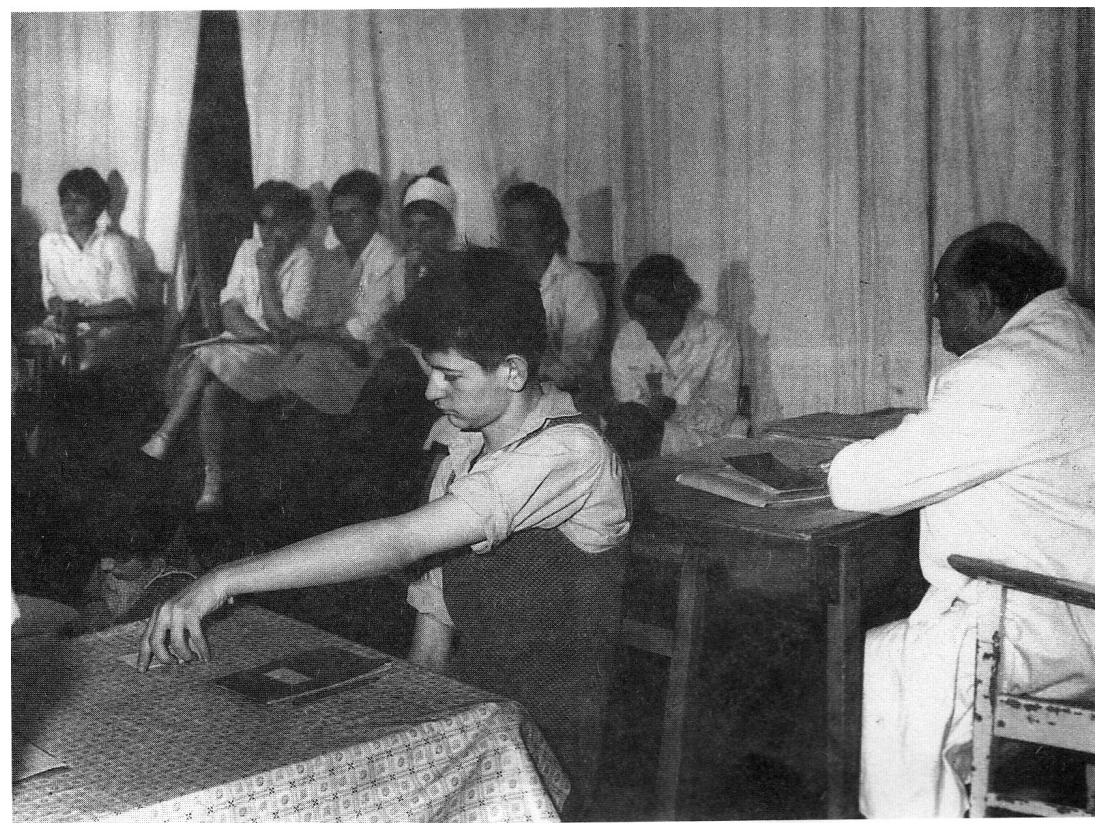

6a Hand ecercise 


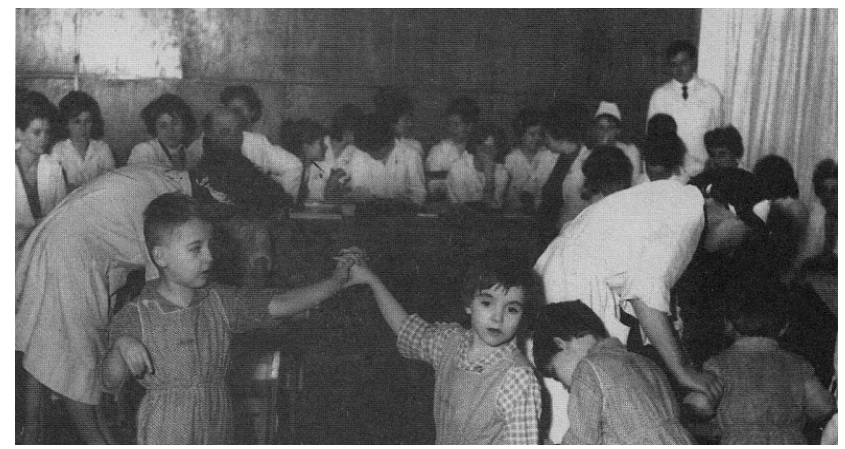

7. Play thread and needle

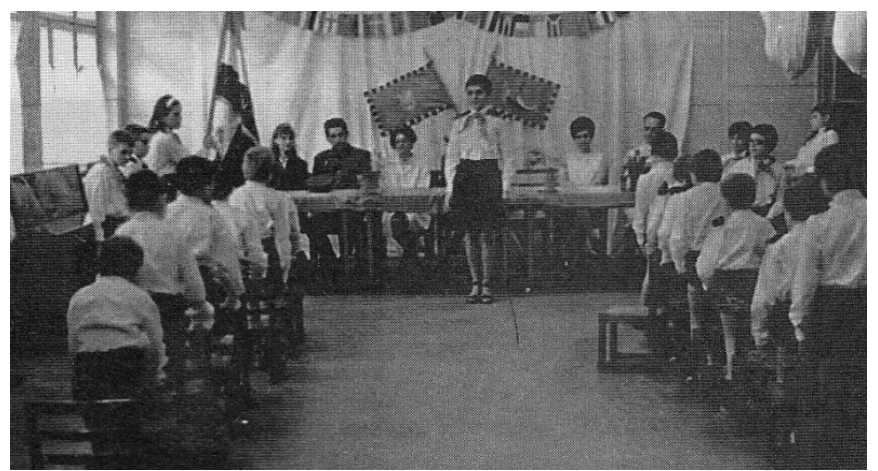

8. At Pioneer Ceremony (stand up unaided)

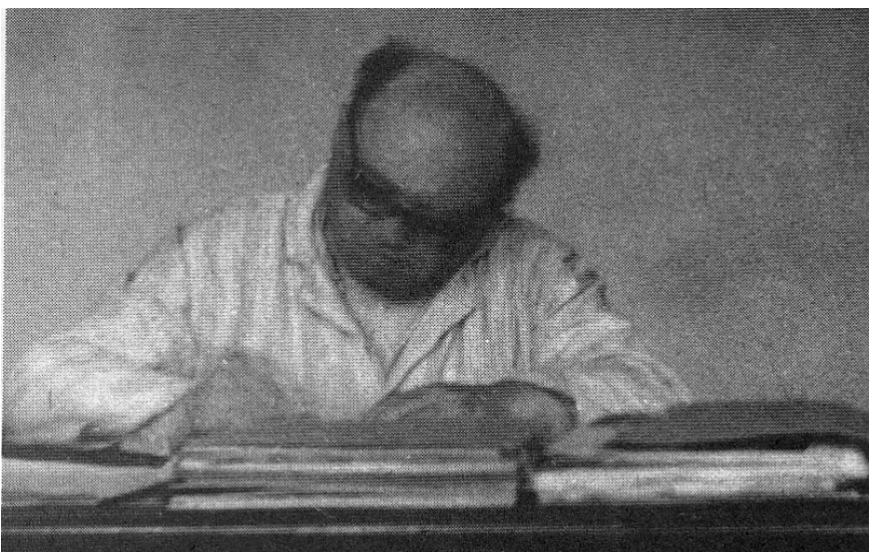

9. The boss 

Later I became a doctor myself and I now understand that, although my paralysed muscles were not improved, I was taught to make much better use of my usable muscles and they were much strengthened. But above all else

I was taught one thing of inestimable value: 'I am what every man is, grandeur' as the great Hungarian poet Ady wrote. I was taught there that my intrinsic value as a human being is not decreased with my decreased mobility and that, if they will it strongly enough a disabled people can live in the world. It is probably thanks to the time I spent in the Institute that I later had the willpower to finish Medical University, become qualified and start a family...

(Dr. Katalin Hidvégi)

I have to tell you honestly that I thought it was a load of rubbish. But later both my wife and I were there when one of these paralysed children, a seven- to eight-year old boy, took his first step in his life. Then the conductor said to the group: 'Let's count together with Joe!' And while the

group was counting, Joe's paralysed leg started moving and he put it forward. He was beet-red from excitement and the whole group was screaming like the football fans at the victory of their team. And then Joe took a step."

(Dr. Károly Akos)

'Today was the happiest day of my life. A 5-year-old child, who could not utter a single sound before, blew out a candle today.'

(Dr. András Petö)

...sometimes we had to complete tasks, such as a motor disabled child would have to go and fetch his mug, and then get back to his place. It was up to us whether they did it with the aid of a chair, a stick or with the help of one of the other children. We were given tools to use, which helped. Self-reliance was very important, very much stressed.

(Erik Szauder) 